NBER WORKING PAPER SERIES

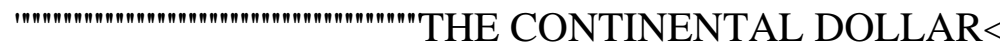 \\ HOW THE AMERICAN REVOLUTION WAS FINANCED WITH PAPER MONEY - INITIAL \\ DESIGN AND IDEAL PERFORMANCE \\ Farley Grubb \\ Working Paper 19577 \\ http://www.nber.org/papers/w19577
}

\author{
NATIONAL BUREAU OF ECONOMIC RESEARCH \\ 1050 Massachusetts Avenue \\ Cambridge, MA 02138 \\ October 2013
}

Preliminary versions were presented at Queens University, Kingston, Canada, 2010; University of Cambridge, Cambridge, UK, 2010; the National Bureau of Economic Research, Cambridge, MA, 2011; the annual meeting of the Economic History Association, Boston, MA, 2011; the University of Delaware, Newark, DE, 2011; the Conference on "The American Constitution: 225th Anniversary of the Ratification" sponsored by the National Science Foundation held at the University of Georgia, Athens, GA, March 2013; and the Seventh World Congress of Cliometrics, Honolulu, Hawaii, 2013. The author thanks the participants for their comments. Research assistance by John Bockrath, Jiaxing Jiang, and Zachary Rose, and editorial assistance by Tracy McQueen, are gratefully acknowledged. The views expressed herein are those of the author and do not necessarily reflect the views of the National Bureau of Economic Research.

NBER working papers are circulated for discussion and comment purposes. They have not been peerreviewed or been subject to the review by the NBER Board of Directors that accompanies official NBER publications.

(C) 2013 by Farley Grubb. All rights reserved. Short sections of text, not to exceed two paragraphs, may be quoted without explicit permission provided that full credit, including $\bigcirc$ notice, is given to the source. 
The Continental Dollar $\square$ How the American Revolution was Financed with Paper Money—Initial Design and Ideal Performance

Farley Grubb

NBER Working Paper No. 19577

October 2013

JEL No. E51,E52,E61,E63,H56,H63,N11,N21,N41

\begin{abstract}
The purpose of this paper is to convince the reader that the Continental dollar was a zero-interest bearer bond and not a fiat currency-thereby overturning 230 years of scholarly interpretation; to show that the public and leading Americans knew and acted on this fact, and to illustrate the ideal performance of the Continental dollar as a zero-interest bearer bond. The purpose of establishing the ideal performance is to create a benchmark against which empirical measures of depreciation can be evaluated in future papers.
\end{abstract}

Farley Grubb

University of Delaware

Economics Department

Newark, DE 19716

and NBER

grubbf@udel.edu 


\title{
The Continental Dollar: How the American Revolution was Financed with Paper Money_-Initial Design and Ideal Performance
}

\author{
Farley Grubb
}

On the commencement of the late revolution, Congress had no money. The external commerce of the states being suppressed, the farmer could not sell his produce, and of course could not pay a tax. Congress had no resource then but in paper money. Not being able to lay a tax for it's redemption they could only promise that taxes should be laid for that purpose so as to redeem the bills by a certain day.

Thomas Jefferson, Jan.-Feb., $1786^{1}$

The purpose of this paper is to convince the reader that the Continental dollar was a zerointerest bearer bond and not a fiat currency_thereby overturning 230 years of scholarly interpretation; to show that the public and leading Americans knew and acted on this fact, and to illustrate the ideal performance of the Continental dollar as a zero-interest bearer bond. The purpose of establishing the ideal performance is to create a benchmark against which empirical measures of depreciation can be evaluated in future papers.

In a series of resolutions from 22 June through 26 December 1775, Congress determined the quantity, nominal value, denominational spacing, and redemption method for the first two emissions of Continental dollars. Congress maintained this structural design in all subsequent emissions, changing only the quantity emitted and denominational spacing, see Table 3.1. Separate emissions are identified by the dates printed on the bills (see Newman 2008, pp. 37, 6373). In total, there were 11 emissions. The dates on the bills allowed the public to distinguish between emissions and identify the corresponding congressional redemption instructions for each emission. Congressional debates were closed to the public and the delegates were placed "under

\footnotetext{
${ }^{1}$ Boyd (1954, v. 10, p. 25).
} 
Table 3.1 Continental Dollar Redemption/Maturity Dates Set by Congressional Legislation

\begin{tabular}{|c|c|c|c|c|c|}
\hline $\begin{array}{l}\text { Procedural } \\
\text { Authorization } \\
\text { Dates }\end{array}$ & $\begin{array}{l}\text { Date Printed } \\
\text { on the Bill } \\
\text { (Emission \#) }\end{array}$ & $\begin{array}{l}\text { Stated S } \\
\text { Redemp } \\
\text { Option }\end{array}$ & $\begin{array}{l}\text { cie } \\
\text { Redemption/Maturity Dates }\end{array}$ & $\begin{array}{l}\text { Current New } \\
\text { Emission }\end{array}$ & $\begin{array}{l}\text { Applied to Other } \\
\text { Emissions }\end{array}$ \\
\hline July 29, 1775 & $\begin{array}{l}\text { May 10, } 1775 \\
(\text { Emission \#1) }\end{array}$ & yes & $\begin{array}{l}1 / 4 \text { on or before Nov. } 30,1779 \\
1 / 4 \text { on or before Nov. } 30,1780 \\
1 / 4 \text { on or before Nov. } 30,1781 \\
1 / 4 \text { on or before Nov. } 30,1782\end{array}$ & $\$ 1,000,000^{d}$ & $\begin{array}{l}\$ 2,000,000 \text { from } \\
\text { 22 June } 1775\end{array}$ \\
\hline Dec. 26, 1775 & $\begin{array}{l}\text { Nov. 29, } 1775 \\
\text { (Emission \#2) }\end{array}$ & yes & $\begin{array}{l}1 / 4 \text { on or before Nov. } 30,1783 \\
1 / 4 \text { on or before Nov. } 30,1784 \\
1 / 4 \text { on or before Nov. 30, } 1785 \\
1 / 4 \text { on or before Nov. } 30,1786\end{array}$ & $\$ 3,000,000$ & \\
\hline Feb. 21, 1776 & $\begin{array}{l}\text { Feb. 17, } 1776 \\
\text { (Emission \#3) }\end{array}$ & --- & $\begin{array}{l}\text { "on the same security as the sums } \\
\text { of money heretofore emitted..." }\end{array}$ & $\$ 3,937,220$ & \\
\hline May 22, 1776 & $\begin{array}{l}\text { May 9, } 1776 \\
(\text { Emission \#4) }\end{array}$ & yes $^{\mathrm{a}}$ & $\begin{array}{l}\text { "in such manner...as Congress } \\
\text { shall hereafter direct...", }\end{array}$ & $\$ 5,000,000$ & \\
\hline Aug. 13, 1776 & $\begin{array}{l}\text { July 22, } 1776 \\
\text { (Emission \#5) }\end{array}$ & yes $^{\mathrm{a}}$ & “ & $\$ 5,000,000$ & \\
\hline Nov. 2, 1776 & $\begin{array}{l}\text { Nov. 2, } 1776 \\
\text { (Emission \#6) }\end{array}$ & --- & 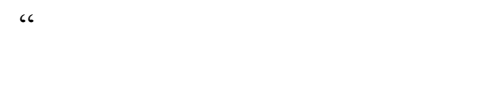 & $\$ 5,000,000$ & \\
\hline Feb. 26, 1777 & $\begin{array}{l}\text { Feb. 26, } 1777 \\
\text { (Emission \#7) }\end{array}$ & --- & $\begin{array}{l}\text { "periods...that shall be fixed } \\
\text { by Congress..." }\end{array}$ & $\$ 5,000,000$ & \\
\hline May 22, 1777 & $\begin{array}{l}\text { May 20, } 1777 \\
\text { (Emission \#8) }\end{array}$ & --- & nothing mentioned & $\$ 5,000,000$ & \\
\hline Aug. 15, 1777 & “ & --- & “ & $\$ 1,000,000$ & \\
\hline Nov. 7, 1777 & “ & --- & “ & $\$ 1,000,000$ & \\
\hline Dec. 3, 1777 & “ & --- & “ & $\$ 1,000,000$ & \\
\hline Jan. 8, 1778 & “ & --- & “ & $\$ 1,000,000$ & \\
\hline Jan. 22, 1778 & “ & --- & “ & $\$ 2,000,000$ & \\
\hline Feb. 16, 1778 & “ & --- & “ & $\$ 2,000,000$ & \\
\hline Mar. 5, 1778 & “ & --- & “ & $\$ 2,000,000$ & \\
\hline Apr. 4, 1778 & “ & --- & “ & $\$ 1,000,000$ & \\
\hline Apr. 11, 1778 & $\begin{array}{l}\text { Apr. 11, } 1778 \\
\text { (Emission \#9) }\end{array}$ & --- & “ & $\$ 5,000,000$ & \\
\hline Apr. 18, 1778 & $\begin{array}{l}\text { May 20, } 1777 \\
\text { (Emission \#8) }\end{array}$ & --- & “ & $\$ 500,000$ & \\
\hline May 22, 1778 & $\begin{array}{l}\text { Apr. 11, } 1778 \\
\text { (Emission \#9) }\end{array}$ & --- & “ & $\$ 5,000,000$ & \\
\hline June 20, 1778 & " & --- & “ & $\$ 5,000,000$ & \\
\hline July 30, 1778 & “ & --- & “ & $\$ 5,000,000$ & \\
\hline Sept. 5, 1778 & “ & --- & “ & $\$ 5,000,000$ & \\
\hline
\end{tabular}




\begin{tabular}{|c|c|c|c|c|c|}
\hline Sept. 26, 1778 & $\begin{array}{l}\text { Sept. 26, } 1778 \\
\text { (Emission \#10) }\end{array}$ & --- & “ & $\$ 10,000,100$ & \\
\hline Nov. 4, 1778 & " & --- & “ & $\$ 10,000,100$ & \\
\hline Dec. 14,1778 & “ & --- & “ & $\$ 10,000,100$ & \\
\hline Jan. 2, 1779 & $\begin{array}{l}\text { Jan. 14, } 1779 \\
\text { (Emission \#11) }\end{array}$ & yes ${ }^{b}$ & $\begin{array}{l}\$ 15,000,000 \text { for } 1779 \text { and } \\
\text { annually } \$ 6,000,000 \text { for } 18 \\
\text { years to } 1 \text { January } 1797 \text {, with } \\
\text { any additional emissions in } \\
1779 \text { redeemed in the same } \\
\text { manner and within the same } \\
\text { time period }^{C}\end{array}$ & $\$ 8,500,395$ & $\begin{array}{l}\text { applies to all } \\
\text { prior emissions } \\
\text { and to all } \\
\text { subsequent } \\
\text { emissions to } \\
1780\end{array}$ \\
\hline Feb. 3, 1779 & $\begin{array}{l}\text { Sept. 26, } 1778 \\
\text { (Emission \#10) }\end{array}$ & yes ${ }^{b}$ & nothing new added & $\$ 5,000,160$ & \\
\hline Feb. 19, 1779 & “ & yes ${ }^{b}$ & “ & $\$ 5,000,160$ & \\
\hline April 1, 1779 & “ & yes ${ }^{b}$ & “ & $\$ 5,000,160$ & \\
\hline May 5, 1779 & “ & yes ${ }^{b}$ & “ & $\$ 10,000,100$ & \\
\hline June 4, 1779 & “ & yes $^{b}$ & “ & $\$ 10,000,100$ & \\
\hline July 17,1779 & $\begin{array}{l}\text { Jan. 14, } 1779 \\
\text { (Emission \#11) }\end{array}$ & yes ${ }^{b}$ & “ & $\$ 5,000,180$ & \\
\hline July 17, 1779 & $\begin{array}{l}\text { Sept. 26, } 1778 \\
\text { (Emission \#10) }\end{array}$ & yes ${ }^{b}$ & “ & $\$ 10,000,100$ & \\
\hline Sept. 17,1779 & $\begin{array}{l}\text { Jan. 14, } 1779 \\
\text { (Emission \#11) }\end{array}$ & yes ${ }^{b}$ & “ & $\$ 15,000,260$ & \\
\hline Oct. 14,1779 & “ & yes ${ }^{b}$ & “ & $\$ 5,000,180$ & \\
\hline Nov. 17,1779 & “ & yes ${ }^{b}$ & “ & $\$ 10,050,540$ & \\
\hline Nov. 29, 1779 & “ & yes ${ }^{b}$ & “ & $\$ 10,000,140$ & \\
\hline
\end{tabular}

Sources: Grubb (2008, p. 286; 2012a); JCC (v. 2, pp. 103, 105, 207, 221-3; v. 3, pp. 390, 398, 407, 457-9; v. 4, pp. 156-7, 164-5, 339-40, 374, 380-3; v. 5, pp. 599, 651, 724-8; v. 6, pp. 918, 1047; v. 7, p. 161; v. 8, pp. 37780, 646-7; v. 9, pp. 873-4, 993; v. 10, pp. 26, 28, 36, 82-3, 86, 174-5, 223-5, 308-12, 337-8, 364-5; v. 11, pp. 521-4, 627, 731-2; v. 12, pp. 884, 962, 967, 1073, 1100-01, 1133, 1217-18, 1266; v. 13, pp. 20-3, 64-5, 139-41, 209-10, 408-9; v. 14, pp. 548, 557-8, 687-8, 848-9; v. 15, pp. 1076-7, 1171-2, 1285, 1324-5); PCC (m247, reel 33, item 26, 'Reports of the Committee on the Treasury and Finance, 1776-1788', pp. 1-5, 13-14; m247, reel 145, item 136, 'Reports of the Board of Treasury, 1776-1781, Volumes 1-2 (1776-1778)', v. 1, pp. 181, 355-7, 462, 507; v. 2, pp. 29, 83, 125, 199, 217, 373, 427, 529, 573, 669, 761; m247, reel 146, item 136, 'Reports of the Board of Treasury, 1776-1781, Volume III 1779', pp. 69, 111, 209, 215, 351, 477, 641, 727, 817, 845).

Notes: Dates are for when the most procedural details were given for each emission. An emission is all bills issued with the same date printed on the bill (Newman 1997, pp. 58-69, 2008, pp. 62-73). After emissions \#7, each emission had several authorizing resolutions where additional amounts were added to a given emission.

${ }^{\mathrm{a}}$ Stated in coinage rating resolutions but not in emission resolutions (JCC v. 4, pp. 339-40, 382; v. 5, p. 724; v. 7, p. 36).

${ }^{\mathrm{b}}$ The specie redemption option for citizens at the Continental Treasury was not mentioned in the 2 and 14 January 1779 resolutions. However, Congress indicated that it was still operative on 14 June 1779 (JCC v. 14, p. 728).

${ }^{\mathrm{C}}$ By the end of 1779 a total of \$199,989,995 net new Continental dollars had been emitted. To redeem all 
the Continental dollars as the 2 January 1779 resolution specified would entail raising the annual payments over the 18 year period (1780 to 1797 ) from $\$ 6,000,000$ to $\$ 10,277,222$. See also note d. This number is net of some undetermined amount of Continental dollar remittances received from the states after 1779 that the resolution allowed to be re-spent to pay off loan office certificate principal and interest incurred before 1780. Total state remittances after 1779 , therefore, had to be somewhat higher than $\$ 10,277,222$ per year to account for permanently removing these re-spent Continental dollars from circulation.

${ }^{\mathrm{d}}$ On 25 July 1775, Congress ordered \$1,000,000 struck in $\$ 30$ bills (JCC v. 2, p. 207). This is not possible. Either $\$ 999,990$ or $\$ 1,000,020$ can be struck, but not $\$ 1,000,000$. Which was done and whether other denominations of emission \#1 were adjusted to accommodate the $\$ 1,000,000$ target in $\$ 30$ bills is not known. Because no change in the $\$ 1,000,000$ total authorized was ever noted by Congress or the Board of Treasury, it is assumed that the discrepancy was made up by adjusting the printing of bills of other denominations from this emission, thus yielding the reported total here of $\$ 199,989,995$. However, the total cumulative net new emissions could vary between $\$ 199,989,985$ and $\$ 199,990,015$ depending how Congress resolved its order to emit \$1,000,000 in \$30 bills on 25 July 1775 - an outcome that is currently unknown.

the strongest obligation of honor" to keep such secret. Why congressmen structured the Continental dollar the way they did, therefore, must be deduced primarily from their actions. ${ }^{2}$

The face value of a Continental dollar was set equal to a Spanish silver dollar- so indicated on the face of each bill (see Newman 2008, pp. 37, 63-73). For the first emission, the initial three million - those with the date May 10, 1775 printed on the bills, Congress passed redemption instructions on 29 July 1775 . States were to remit fixed quotas of Continental dollars to the Continental Treasury to be burned. Each state's quota was roughly proportional to its respective population share in the union. Congress explicitly left each state free to decide how best to redeem Continental dollars from the citizens within its jurisdiction. State remittances to the Continental Treasury were to be in four equal yearly installments spread over a contiguous four-year period, beginning on 30 November 1779 and ending on 30 November 1782. No contemporaneous taxes or other debts payable to the states in these Continental dollars were required before the redemption years indicated. No state was required to remit more than its quota, and Continental dollars paid no interest. States with a quota deficiency of Continental dollars were to make it up in specie at face value. The Continental treasurer was to retain this

\footnotetext{
${ }^{2}$ See JCC (v. 2, p. 22; v. 3, pp. 342-3); Newman (1997, pp. 58-69; 2008, pp. 62-73). The private letters written by congressmen reveal little (Bolles 1884, v. 1, p. 27; Smith 1976, v. 1-2).
} 
specie and advertise its availability. Citizens with Continental dollars in states that had filled their quotas and had ceased redeeming Continental dollars could redeem them at face value for specie directly from the Continental Treasury, in effect claiming the specie remitted by the states with a quota deficiency of Continental dollars. ${ }^{3}$

The adoption of this last provision indicated that Congress anticipated that by 1779, when state redemption of Continental dollars would commence, a geographic imbalance of Continental dollars relative to state redemption quotas would exist. The exigency of war would cause paper money spent on troops and supplies to be concentrated in the theaters of war. These theaters were unlikely to be spread evenly among the states per their population shares in the union. Congress provided an ingenious solution to the anticipated geographic imbalance in the location of Continental dollars that rebalanced the availability of these dollars with state quota claims. This rebalancing was necessary to insure fairness and stem jealousies among the states regarding who would shoulder the financial burden of the war. This provision also anchored the value of a Continental dollar to its face value in specie at the specific future date set for its redemption.

Before the Revolution, colonies had employed this same method for rebalancing paper money redemption requirements within their respective colonies. When a colony emitted paper money, it also set future taxes to redeem and remove that paper money from circulation. Upon redemption, the paper money would be destroyed. Colonial assemblies realized that future tax burdens to retire the paper money and the possession of that paper money among its subjects would not be perfectly synchronized. The transaction costs of trading paper money among a colony's subjects to perfectly realign each subject's possession of paper money with that subject's tax obligations by the time taxes were due were burdensome and fraught with potential

${ }^{3} J C C$ (v. 2, pp. 106, 221-3; v. 3, p. 407). 
hold-ups and leveraged rent-seeking of one subject against another.

Colonial assemblies solved this problem by allowing subjects to pay their taxes either in the colony's paper money or in some other medium, such as in grain or specie at a fixed rate to the colony's paper money. Subjects that did not have, or could not acquire in time, the colony's paper money, paid their taxes in these other media. Subjects that had more paper money than they owed in taxes could then directly cash in their excess balances of paper money at the colony's treasury for the grain or specie paid by the subjects who did not have the paper money to pay their taxes. Because final paper-money-redemption taxes were set equal to the quantity of paper money emitted, this method perfectly rebalanced tax obligations and paper money claims among the colony's subjects. ${ }^{4}$ As such, the specie redemption option in the Continental dollar resolutions, namely the provision that allowed citizens in states where redemption quotas were already filled to cash in their excess Continental dollars at the Continental Treasury for their face value in specie thereby claiming the specie paid in by states with a deficient amount of Continental dollars, would have been familiar to Americans. Its presence, design, and purpose in these Continental dollar resolutions were likely expected and understood by the public.

Congress placed the redemption of the first emission four to seven years into the future because that was when the war was expected to be over. For example, Silas Deane, congressman from Connecticut, wrote 1 July 1775, "The Warr will not last Seven Years if I have any Judgment in Matters." ${ }^{5}$ At that point, trade would resume and generate the income necessary to pay the taxes needed to redeem Continental dollars at face value in specie. Most congressmen

\footnotetext{
${ }^{4}$ For examples, see the paper money issued by Massachusetts between 1690 and 1738; Connecticut between 1709 and 1734, and in 1740 and 1746; New Hampshire between 1709 and 1741; Rhode Island between 1710 and 1739; New York between 1709 and 1724; New Jersey between 1709 and 1725; and Pennsylvania in 1723 (Bush 1977, pp. 63-6, 68-70, 109-3, 209-13; Grubb 2012b; Newman 2008, pp. 90-7, 102, 184-97, 224-31, 248-9, 270-6, 332, 37281).

${ }^{5}$ Smith (1976, v. 1, p. 567).
} 
understood that the United Colonies were rich in assets, e.g. possessing abundant land, slaves, oxen, etc., but poor in cash. Specie to pay taxes rested on foreign trade-Americans selling their produce to foreigners for specie. This trade was disrupted by war via import and export embargos imposed by Congress and the British blockade of foreign trade. Congress opened American ports to non-British trade on 6 April $1776 .{ }^{6}$ This trade disruption also meant that the ability to acquire specie to pay interest to the holders of Continental dollars in the interim before redemption was in doubt. As such, being unable to make interest payments certain, no interest payments were attached to the Continental dollar in Congress' redemption resolutions.

For the second emission, the next three million-those with the date November 29, 1775 printed on the bills, Congress passed redemption instructions on 26 December 1775. These instructions were identical to those for the first emission, except that the four-year redemption window was explicitly voted to be moved forward to begin after the last of the first emission was redeemed, namely to begin on 30 November 1783 and end on 30 November $1786 .^{7}$ Richard $^{2}$ Smith, congressman from New Jersey, wrote in his diary on 23 December 1775 that "[James] Duane [congressman from New York] gave in a Sett of Resolves for Sinking the last 3 Millions of Dollars, similar to those of the former 3 Millions \& to be sunk in the same Years. They were all agreed to except the Time of Sinking which required further consideration.” That further consideration was taken up three days later. Smith wrote in his diary on 26 December 1775,

\footnotetext{
${ }^{6}$ On congressional trade embargos, see $J C C$ (v. 1, pp. 41, 43, 51-3, 57, 62, 75-81, 113; v. 2, pp. 54, 67, 70-2, 78, 125, 184-5, 200-2, 235, 238-9, 247, 251-2; v. 3, pp. 268-9, 280, 292-4, 306, 308, 314-5, 317, 362-4, 389-90, 395-6, 408-9, 420-2, 429-30, 437-9, 455, 457, 460-1, 464-5, 476-85, 493-504; v. 4, pp. 62, 96, 172, 183, 257-9; v. 6, pp. 1071-2; v. 12, p. 1165). See also Buel (1998); O'Shaughnessy (2000). For examples of comparable assessments expressed by leading American revolutionaries, such as Charles Carroll, Samuel Chase, Silas Deane, James Duane, Benjamin Franklin, John Jay, Thomas Jefferson, Henry Laurens, Richard Henry Lee, Francis Lewis, Robert R. Livingston, Jr., James Madison, Gouverneur Morris, John Rutledge, Joseph Warren, Oliver Wolcott, George Wythe, John Joachim Zubly, and the Board of Treasury, see Boyd (1954, v. 10, p. 25); Hutchinson and Rachal (1962, v. 1, p. 305); $J C C$ (v. 2, p. 25; v. 3, pp. 477, 479-80, 498, 499, 501, 503; v. 6, pp. 1071-2; v. 12, pp. 1048-50; v. 13, p. 20; v. 14, p. 649; v. 15, pp. 1052, 1055-7; v. 16, p. 262; v. 19, pp. 406-8); Oberg (1998, v. 34, p. 229); Sparks (1832, v. 1, p. 38); Smith (1981, v. 7, pp. 462-3; 1986, v. 13, pp. 351-2).

${ }^{7}$ See JCC (v. 3, pp. 457-9); Smith (1977, v. 2, pp. 517-8, 524).
} 
"Duanes Proposition for sinking the last 3 Million of Dollars were gone thro, the Vote was taken Whether that Money shall be sunk in the Years 1779, 1780, 1781 \& 1782 as the last 3 Million, or in the Years 1783, 1784, 1785 \& 1786 and carried for the latter."

This vote is important because it shows that the selection of a redemption window was not an afterthought or just some resolution boilerplate. It was a significant choice based on serious deliberations among alternatives. It was an issue that mattered. This vote established that redemption windows would be emission specific and created a precedent that would govern how expectations would be formed for forecasting the redemption of future emissions. It also provides insight into what motivated the particular structural design of the Continental dollar adopted by Congress.

The redemption of the first emission of Continental dollars amounted to $\$ 750,000$ per year, which implied an average tax per white-capita per year of $\$ 0.33$. In the 13 colonies between 1770 and 1774, the average tax per white-capita per year for all taxes was $\$ 0.41 .^{9}$ Spreading the redemption of the first emission over a contiguous four years in order to lower per white-capita per year taxes to historically acceptable and feasible levels is the only sensible explanation for adopting a multi-year redemption window.

In general, multi-year redemption windows were problematic. They caused uncertainty in the realized values of Continental dollars from the same emission. While the average or expected value of a Continental dollar from the first emission can be estimated given the four-year span of the redemption window, not knowing which specific Continental dollar would be redeemed in 1779 and which in 1782 meant that the realized value of a Continental dollar varied around that average by the waiting cost spanned by the redemption window. If citizens could determine

\footnotetext{
${ }^{8}$ See Smith (1977, v. 2, pp. 517-8, 524).

${ }^{9}$ Derived from Carter, et al. (2006, v. 1, p. 25; v. 5, pp. 652-3); McCusker (1978, p. 10); Rabushka (2008, pp. 796, 825, 862-3).
} 
which dollar would be redeemed in which year, they would be willing in 1775 to pay more for a dollar redeemed in 1779 than for one redeemed in 1782. When visually identical dollar bills are not necessarily of equal present value, this makes for a cumbersome medium of exchange.

As such, the only reason to have a four-year redemption window for the first emission rather than a one-year redemption point was to hold per year per white-capita redemption taxes within historically acceptable and feasible limits. If redemption was not fiscally credible, the system would collapse as citizens would doubt that their dollars would be redeemed at face value as promised. In setting the redemption structure of the first emission, Congress made a tradeoff between fiscal credibility and ease-of-use as a medium of exchange, siding with fiscal credibility. As long as the redemption window for a given emission was relatively short, the variance in the realized value of Continental dollars from that emission would only be a minor inconvenience. This interpretation plays through the second emission and makes sense of the vote over the redemption window for that emission.

Duane's proposal to redeem the second emission in the same time window as the first emission would have doubled the redemption quotas for 1779 through 1782. This in turn would have doubled the taxes each state would have to impose on its citizens to an average tax per year per white-capita of $\$ 0.66$, or 61 percent above that for all taxes raised per year per white-capita in the years preceding the Revolution. A tax level well above the historically acceptable and feasible range would threaten the fiscal credibility of the system and risk precipitating its collapse. When Congress voted to push the redemption of the second emission into a four-year redemption window that started immediately after the last redemption year of the first emission, they were voting to keep the per year per white-capita tax level constant at $\$ 0.33$ for redeeming both emissions, and thus voting to maintain the system's fiscal credibility. 
Adopting Duane's proposal would have had one good consequence. By having both the first and second emissions redeemed in the same four-year window, Duane's proposal would have caused the expected value of a Continental dollar to be the same regardless of emission, i.e. regardless of the date on the bill. Emissions would be fully fungible. Using Continental dollars as a medium of exchange would be easier under Duane's proposal because the expected value of Continental dollars at any point in time would not differ by emission. The realized values of Continental dollars of both emissions would still be subject to the same variance around a common average as discussed above, but that would be a minor inconvenience compared with values varying between emissions.

When Congress rejected Duane's proposal in favor of different redemption windows per emission, they were explicitly accepting that Continental dollars from different emissions at the same point in time would have different expected values. In 1775, having a Continental dollar that would be paid off in specie at face value in 1779 was more valuable than having one that would be paid off in specie at face value in 1786 . Not only was there some minor variance in the realized values of Continental dollars per each emission around the average for that emission, but now at any point in time there was a difference in the expected value of a Continental dollar between emissions. The expected value of a Continental dollar was now contingent on the date printed on the bill. This outcome added to the cumbersomeness of using Continental dollars as a medium of exchange. Again, the only sensible explanation for why Congress voted for this redemption structure was that they were making a tradeoff between holding per year per whitecapita taxes within historically acceptable and feasible limits thus giving the system fiscal credibility, and making Continental dollars an easily tradable or fungible medium of exchange. Again, they sided with fiscal credibility. 
This choice foreshadows a continuing conflict that by 1779 was won by those congressmen, like Duane, who did not understand the need for fiscal credibility or who believed that current tax levels could be pushed substantially above what had been historically experienced without doing harm. These congressmen either did not see a connection between the fiscal credibility of redemption and the value of the Continental dollar or were willing to sacrifice that connection for other political and economic goals. They gravitated toward reinterpreting the Continental dollar as a pure fiat currency, despite its documented structural design, and viewed the Continental dollar's value as being determined primarily by a naïve interpretation of Hume's quantity theory of money.

Continuing with the analysis of the structural design of the initial emissions of Continental dollars, on 23 November 1775 Congress appointed an ad hoc committee on paper money. Richard Smith wrote in his diary on 11 January 1776, “A Report from the Comee. on the Paper Currency was ably argued for 4 Hours, the Report recommended that the present 6 Millions of Dollars be called in and large Notes issued to that Amount bearing Interest... "10 Again, Smith's comments show that Congress debated the structural design of the Continental dollar at length. The choices made were not afterthoughts or just resolution boilerplate. They were based on serious deliberations among alternatives. Having the Continental dollar pay yearly interest between emission and redemption was one such alternative design. This proposal was made, debated upon, and not adopted. Most likely the majority of congressmen saw the paying of yearly interest as impractical given the absence of wartime tax revenue with which to pay interest. The Continental dollar would remain a zero-interest bearer bond with defined future specie payoff dates.

\footnotetext{
10 Smith (1978, v. 3, p. 83). This 23 November 1775 committee was comprised of John Jay, Benjamin Franklin, Samuel Adams, Thomas Johnson, George Wythe, Edward Rutledge, and Thomas Jefferson (JCC v. 3, pp. 367-8). This committee's report will be analyzed further in future papers.
} 
Richard Smith's influence on the initial structural design of the Continental dollar may go deeper than just diary observations. He was present for all congressional paper money deliberations from 10 May 1775 to 30 March 1776 . He would be appointed by Congress to a standing committee created on 17 February 1776 for superintending the treasury and overseeing the emission of Continental dollars. ${ }^{11}$ Among the documents and letters that have survived, he was the only congressman to note the congressional debates on redemption windows and interest payments for the first two emissions. Smith's brother, Samuel Smith, was New Jersey State Treasurer, and Richard left Congress on 30 March 1776 to succeed his brother, who had died, as New Jersey State Treasurer. Richard Smith's public finance expertise and intimate knowledge of colonial New Jersey's paper money system may have influenced the congressional debates that crafted the initial structural design of the Continental dollar.

The Continental dollar and the colonial New Jersey paper pound shared many unique circumstances and design features. Colonial New Jersey's last emission of paper money was during a war, namely the French and Indian War, 1755-1764. The redemption of these wartime emissions was designed to take place well after the war had ended. The Continental dollar was emitted under similar wartime circumstances with the same post-war redemption intention. Both the Continental dollar and the colonial New Jersey pound had their specie value printed on the face of each bill, see Figure 3.1 and compare it with Newman (2008, pp. 37, 63-73). Most colonial paper monies did not have this feature. ${ }^{12}$ Both the Continental dollar and the colonial New Jersey pound paid no interest. Both had explicit redemption dates set well into the future and spread out to hold per year per-white capita taxes within fiscally feasible limits.

\footnotetext{
11 JCC (v. 4, pp. 156-7).

12 See Grubb (2012b); Newman (1997, 2008).
} 


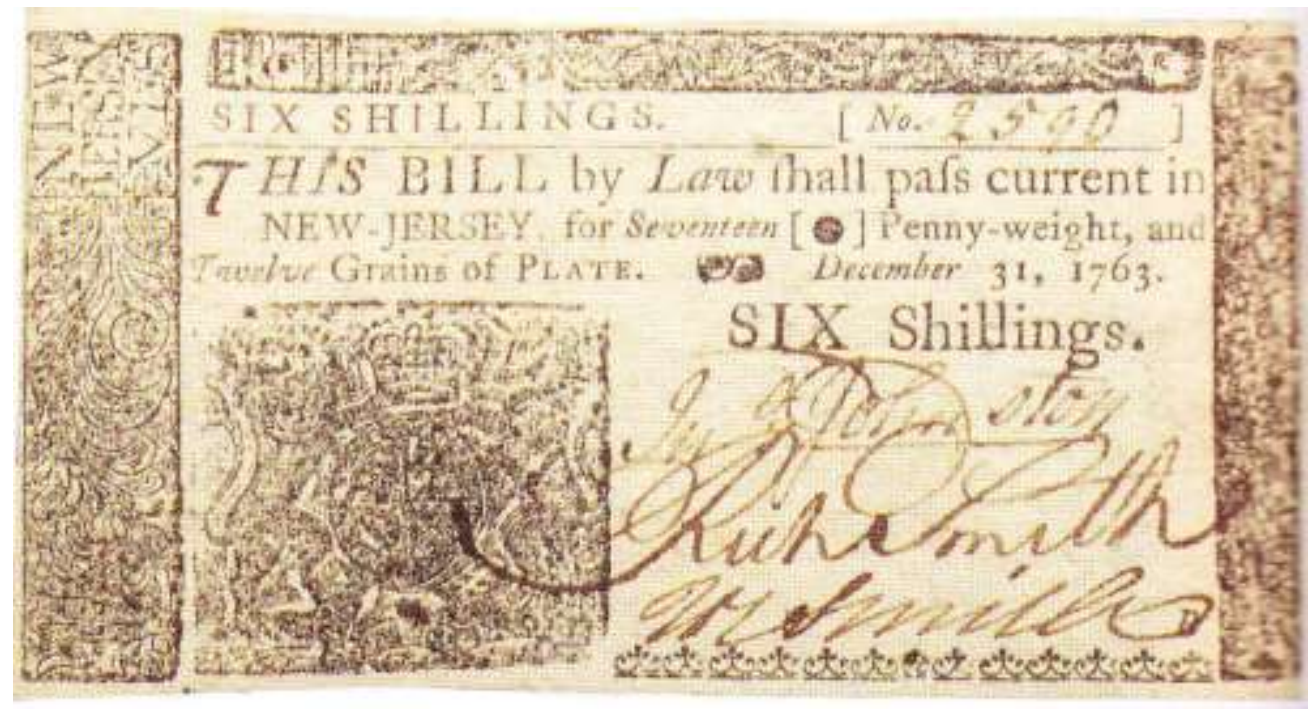

Figure 3.1 Example of New Jersey Paper Money, Issued 31 December 1763

Source: Newman (2008, p. 258).

Notes: "Plate" refers to silver (specie). 20 penny-weight, of 24 grains each, equals one troy ounce of silver plate. Six shillings in New Jersey pounds equals 0.3 New Jersey pounds which is set equal to 0.875 ounces of silver, or $0.3429 \mathrm{New}$ Jersey pounds equals one ounce of silver, at face value. One pound sterling equals 3.8715 ounces of silver, or one ounce of silver equals 0.2583 pounds sterling. Therefore, by equating both to one ounce of silver, 0.3429 New Jersey pounds at face value equals 0.2583 pounds sterling, or 1.3275 New Jersey pound at face value equals one pound sterling. See McCusker (1978, pp. 8-10).

Each year the French and Indian War continued, New Jersey emitted more bills of credit to meet unexpected war expenses until by 1764 a total of 347,500 New Jersey pounds, approximately $\$ 1,189,944$, in new bills had been emitted, see Table 3.2. This was over 2.5 times the amount New Jersey had emitted over its entire prior history of issuing paper money (17091754). ${ }^{13}$ Similarly, new emissions of Continental dollars would be required as long as the War for Independence continued, with the total amount emitted rising to many times what would be considered normal during peacetime. With each new wartime emission, the New Jersey legislature established explicit redemption provisions (maturity dates) by fixing future tax obligations to be paid in its bills. Bills redeemed via taxation were destroyed. The redemption procedure chosen for the Continental dollar was similar to that used by colonial New Jersey.

\footnotetext{
${ }^{13}$ Grubb (2014).
} 
New

Emissions:

Redemption Year and Amount (in thousands of New Jersey Paper Pounds)

Date and

Amount

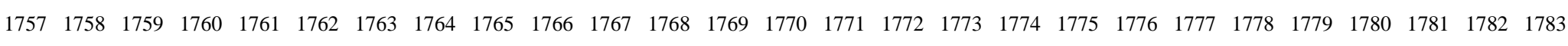

\begin{tabular}{|c|c|c|c|c|c|c|c|c|c|c|c|c|c|c|c|c|c|c|c|c|c|c|c|c|c|c|c|c|}
\hline \multicolumn{29}{|l|}{1755} \\
\hline Apr. & $15,000 £$ & 5 & 5 & 5 & & & & & & & & & & & & & & & & & & & & & & & & \\
\hline Aug. & 15,000 & & 5 & 5 & 5 & & & & & & & & & & & & & & & & & & & & & & & \\
\hline $\begin{array}{l}\text { Dec. } \\
1756\end{array}$ & 10,000 & & & & & 10 & & & & & & & & & & & & & & & & & & & & & & \\
\hline June & 17,500 & & & & & 2.5 & 15 & & & & & & & & & & & & & & & & & & & & & \\
\hline 1757 & & & & & & & & & & & & & & & & & & & & & & & & & & & & \\
\hline Mar. & 10,000 & & & & & & & 10 & & & & & & & & & & & & & & & & & & & & \\
\hline June & 5,000 & & & & & & & 5 & & & & & & & & & & & & & & & & & & & & \\
\hline $\begin{array}{l}\text { Oct. } \\
1758\end{array}$ & 30,000 & & & & & & & & & & & & 5 & 5 & 5 & 5 & 5 & 5 & & & & & & & & & & \\
\hline Apr. & 50,000 & & & & & & & & & & & & & & & & & & 10 & 10 & 10 & 10 & 10 & & & & & \\
\hline $\begin{array}{l}\text { Aug. } \\
1759\end{array}$ & 10,000 & & & & 10 & & & & & & & & & & & & & & & & & & & & & & & \\
\hline $\begin{array}{l}\text { Mar. } \\
1760\end{array}$ & 50,000 & & & & & & & & 12.5 & 12.5 & 12.5 & 12.5 & & & & & & & & & & & & & & & & \\
\hline $\begin{array}{l}\text { Mar. } \\
1761\end{array}$ & 45,000 & & & & & & & & & & & & 7.5 & 7.5 & 7.5 & 7.5 & 7.5 & 7.5 & & & & & & & & & & \\
\hline $\begin{array}{l}\text { Mar. } \\
1762\end{array}$ & 25,000 & & & & & & & & & & & & & & & & & & 5 & 5 & 5 & 5 & 5 & & & & & \\
\hline $\begin{array}{l}\text { Mar. } \\
1763\end{array}$ & 30,000 & & & & & & & & & & & & & & & & & & & & & & & 15 & 15 & & & \\
\hline $\begin{array}{l}\text { Dec. } \\
1764\end{array}$ & 10,000 & & & & & & & & & & & & & & & & & & & & & & & & & 10 & & \\
\hline Feb. & 25,000 & & & & & & & & & & & & & & & & & & & & & & & & & 5 & 15 & 5 \\
\hline Total & $347,500 £$ & 5 & 10 & 10 & 15 & 12.5 & 15 & 15 & 12.5 & 12.5 & 12.5 & 12.5 & 12.5 & 12.5 & 12.5 & 12.5 & 12.5 & 12.5 & 15 & 15 & 15 & 15 & 15 & 15 & 15 & 15 & 15 & 5 \\
\hline
\end{tabular}

Sources: Bush (1980, pp. 15-39, 65-74, 81-2, 104, 124-7, 168-72, 195-213, 219-51, 269-88, 303-4, 307-19, 323-4, 327-55, 373-409, 413-36, 451-88, 495-502, 517-31, 539-55, 559-78, 581-97, 621-56, 663-79; 1982, pp. 5-13, 24-8, 73-89, 97-103, 107-11, 125-40, 153-4, 159-66, 191-8, 207-21, 273-6, 289-316, 385-8, 394, 427-31, 453-6, 505-8, 523-64; 1986, pp. 25-9, 53-9, 64-8, 115-21, 171-7, 212-35, 250-1, 301-6, 327-32, 379-93, 419-22, 437-56); Grubb (2014); Kemmerer (1940, p. 279); Sherwood (1851, p. 147). 
Finally, as the French and Indian War continued and emissions mounted, the New Jersey legislature deliberately spread the redemption of its wartime emissions evenly over a 27 -year time horizon, from 1757 through 1783, see Table 3.2. For the sequence of new emissions from 1755 through mid-1758 and from 1762 through 1764, the New Jersey legislature deliberately staggered their respective redemptions forward in time. In addition, most individual emissions had a three- to six-year contiguous redemption window with per year redemption amounts held constant within that window. For emissions from mid-1758 through 1761, the New Jersey legislature deliberately placed the redemption windows for these emissions so as to even out peryear redemptions for the entire amount of wartime emissions over the 27 year redemption time horizon. In the end, between the last wartime emission in 1764 and 1773, redemption ended up being exactly 12,500 and from 1774 to 1782 ended up being exactly 15,000 New Jersey pounds per year. This put the average redemption tax per white-capita per year for New Jersey residents between $\$ 0.37$ and $\$ 0.45$, close to the tax level for redeeming the first two emissions of Continental dollars. ${ }^{14}$ This deliberate spreading of redemptions evenly over a long horizon held per white-capita per year taxes within feasible limits, thus giving New Jersey's commitment to its paper money fiscal credibility.

Like the redemption of the New Jersey pound, each emission of Continental dollars was designed to have a different contiguous multi-year redemption window sequentially pushed further into the future for each new emission. In addition, like the New Jersey pound, this

\footnotetext{
${ }^{14}$ Derived from Bush (1980, pp. 15-39, 65-74, 81-2, 104, 124-7, 168-72, 195-213, 219-51, 269-88, 303-4, 307-19, 323-4, 327-55, 373-409, 413-36, 451-88, 495-502, 517-31, 539-55, 559-78, 581-97, 621-56, 663-79; 1982, pp. 5-13, 24-8, 73-89, 97-103, 107-11, 125-40, 153-4, 159-66, 191-8, 207-21, 273-6, 289-316, 385-8, 394, 427-31, 453-6, 505-8, 523-64; 1986, pp. 25-9, 53-9, 64-8, 115-21, 171-7, 212-35, 250-1, 301-6, 327-32, 379-93, 419-22, 437-56); Fisher (1911, p. 289); Grubb (2012b, 2014); Kemmerer (1940, p. 279; 1956, p. 136); Lester (1939, pp. 197, 199); Newman (1997, pp. 243-54); Sherwood (1851, p. 147); Wicker (1985, p. 874). Per capita amounts rely on population estimates in Carter, et al. (2006, v. 5, p. 652) with interpolated values between the reported decadal estimates. Currency conversions are taken from McCusker (1978, pp. 8-10). In face value, $1 £_{\mathrm{NJ}}$ (New Jersey pound) $=2.9163$ ounces of silver $=0.7533 £_{\mathrm{S}}$ (pounds sterling). This means that $1.3275 £_{\mathrm{NJ}}=1 £_{\mathrm{S}}=\$ 4.5457$ (Spanish silver dollars). Therefore, $1 \varepsilon_{\mathrm{NJ}}=\$ 3.4243$. See also the notes to Figure 3.1.
} 
redemption structure was designed to hold taxes within fiscally feasible limits. In conclusion, the circumstances of emission, the patterns of redemption, and the structural design of the Continental dollar closely mimicked that of recent colonial New Jersey paper pounds.

New Jersey successfully redeemed its bills at face value on time as legislatively promised, until the Revolution intervened. Preliminary estimates show that the present value of New Jersey's paper money, time-discounted back from its designated redemption dates, closely tracked its current specie exchange rate. These rates fluctuated between 55 and 85 percent of the money's face value. ${ }^{15}$ In other words, the New Jersey paper pound was a savings bond type money where time-discounting explained almost all its current value, i.e. there was little preference or unique liquidity premium to this paper money. It traded below face value not because it had depreciated, but because it was a bond that paid no interest and would not be redeemed at face value until sometime in the future, i.e. it was like a current U.S. savings bond, except that it was transferable.

The initial design of the Continental dollar was virtually identical to, and had all the features of, the colonial New Jersey paper pound. As such, it was not totally new and would likely be familiar and well understood by many Americans. The history of the colonial New Jersey pound also provided a precedent for what Americans could expect regarding the future performance and redemption structure of the Continental dollar. In particular, redemption at face value would only start post-war, would be pushed successively into the future with each subsequent emission, and would be spread over enough years to keep tax levels within historically acceptable and feasible limits, thus giving the system fiscal credibility.

${ }^{15}$ See Grubb (2014). 


\section{THE CONTINENTAL DOLLAR WAS A ZERO-INTEREST BEARER BOND}

Congress' legislated redemption instructions for the first two emissions indicate that Continental dollars were designed to be zero-interest bearer bonds, not fiat currency. They resembled today's U.S. savings bonds more than today's U.S. dollar bills, with the exception that they were transferable. As such, the current par value of a Continental dollar was not its face value, but its present value, namely its face value reduced by time-discounting from its fixed future redemption (maturity) dates. This present value provides the benchmark against which empirical measures of depreciation should be evaluated.

Figure 3.2 illustrates the ideal present-value performance of the first two emissions of Continental dollars, and shows the medium-of-exchange problems arising from its redemption design. Values are discounted back continuously from the final redemption window at 6 percent and expressed as a percentage of face value at each respective point in time. ${ }^{16}$ The ideal presentvalue path assumes that redemption is viewed as credible or certain and that 6 percent represents the opportunity cost or time-preference for such a certain payoff. The expected present value of a Continental dollar starts well below its face value due to time-discounting, 72 and 57 percent of face value in November of 1775 for dollars from emissions \#1 and \#2, respectively. From November 1775, these values rise continuously, reaching face value by the last year of their

\footnotetext{
16 On 17 January 1777, Robert Morris said that 6 percent was the opportunity cost of capital placed in private securities (Smith 1980, v. 6, p. 117). Six percent was also the rate used by the national government for loans between 1776 and 1790, and the most common rate mentioned throughout this period, see Barlow (2012, pp. 110, 125, 128); Elliot (1843); Homer and Sylla (1991, pp. 274-313); Hutchinson and Rachel (1962, v. 1, p. 308); JCC (v. 2, pp. 25-6; v. 6, p. 1037; v. 7, pp. 102-3, 158, 168; v. 8, pp. 725-6; v. 9, pp. 955, 989; v. 10, p. 59; v. 11, p. 416; v. 12, pp. 929-30, 932, 1074, 1256; v. 13, pp. 112, 141, 146-7, 441, 497; v. 14, pp. 717, 720, 731-2, 783, 820, 901; v. 15, pp. 1147, 1197, 1210, 1225, 1245-6, 1288, 1319,1405; v. 16, pp. 264-5, 288; v. 17, pp. 464, 568, 804; v. 18, p. 1017; v. 19, pp. 6, 167; v. 21, p. 903; v. 23, p. 831; v. 24, p. 39; v. 26, p. 32; v. 27, pp. 395-6); Ferguson (1988, v. 7, p. 547); Pennsylvania Gazette (30 April; 21 and 28 May; 25 June; 2, 16, and 23 July 1777); Puls (2008, p. 181); Smith (1979, v. 4, p. 295; 1980, v. 6, pp. 117-8, 212-3, 228-9, 238-9, 245, 252, 259-62, 270, 277, 295, 346, 368, 372, 386, 400-1, 404; 1981, v. 7, pp. 524, 581, 617, 623, 635, 642-3; 1981, v. 8, p. 25; 1983, v. 10, p. 205; 1985, v. 11, pp. 94, 137-8, 361; 1986, v. 13, pp. 132, 604-5; 1987, v. 14, pp. 51, 463, 500; 1988, v. 15, pp. 377, 396; 1989, v. 16, pp. 307-8, 490, 531; 1990, v. 17, p. 365; 1992, v. 19, p. 139; 1994, v. 21, p. 467). On 6 percent being a typical or normal interest rate in eighteenth-century America, see Brock (1975, pp. 260, 328, 332, 435, 462); Davis (1964, v. 1, p. 326; v. 2, pp. 38, 68, 83, 99-100, 315, 321; v. 3, p. 168; v. 4); Nettels (1934, p. 267).
} 


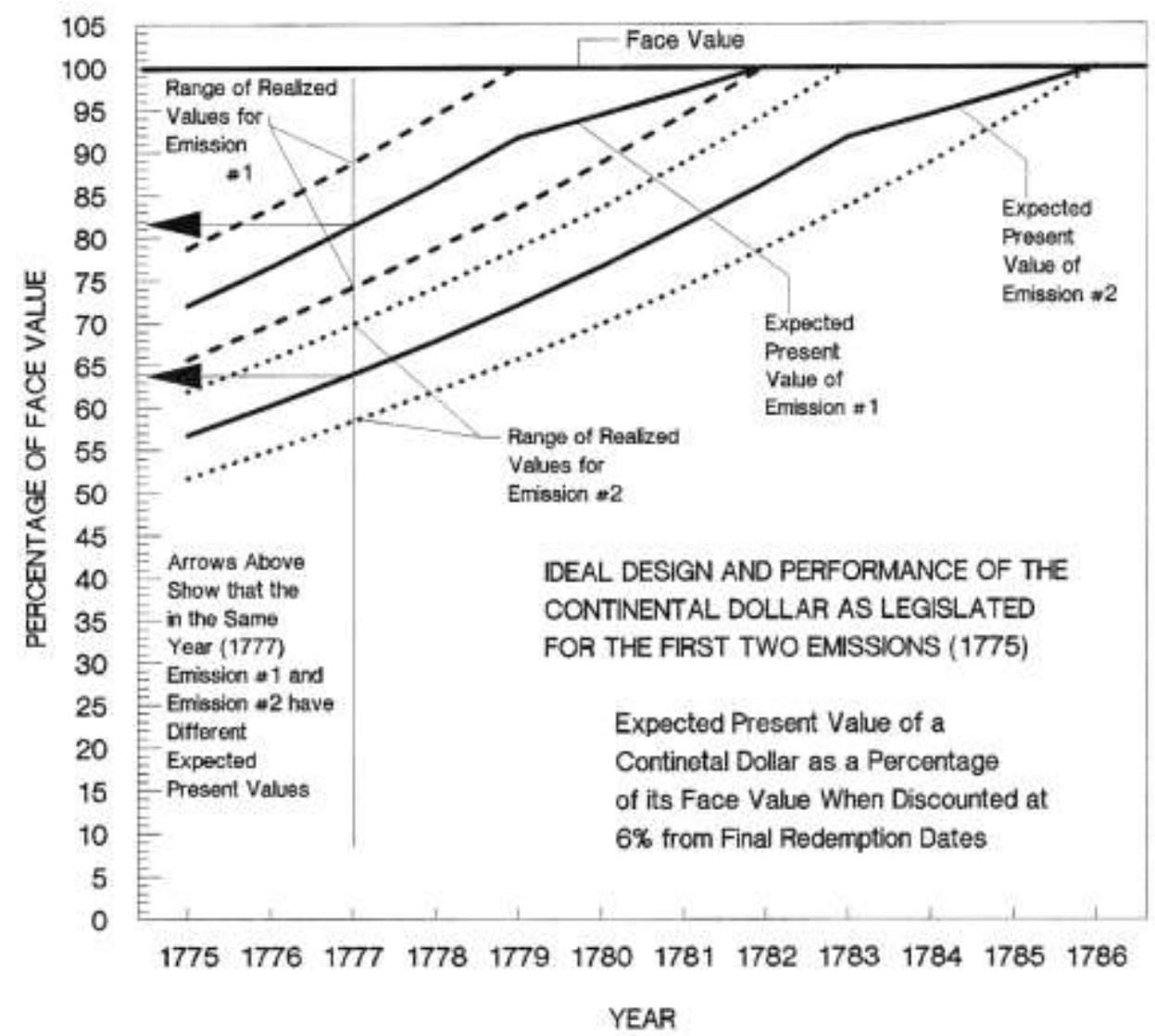

Figure 3.2 Ideal Present-Value Path of the First Two Emissions of Continental Dollars Sources: See Tables 3.1 and 3.4.

respective redemption windows, 1782 and 1786 for emissions \#1 and \#2, respectively.

Figure 3.2 illustrates the two tradeoffs (discussed above) that Congress made between the fiscal credibility of redemption and the cumbersomeness of using Continental dollars as a medium of exchange. For a given emission, a four-year rather than a one-year redemption window increased the fiscal credibility of redemption, but at the cost of making a Continental dollar from a given emission at any point in time have a range of realized values. For example, in 1777, not knowing if a particular Continental dollar from emission \#1 would be redeemed in 1779 or in 1782 meant that the realized value of that Continental dollar discounted back from its possible redemption dates ranged between 87 and 74 percent of face value. For a Continental 
dollar from emission \#2 this range was between 70 and 58 percent of face value, see Figure 3.2. These ranges made using Continental dollars as a medium of exchange cumbersome. When a dollar is not necessarily equal in realized value to an identical-looking dollar at the same point in time and space, trade becomes problematic, i.e. costlier than when a dollar is always equal to an identical-looking dollar.

If a citizen could not determine when any particular Continental dollar from a given emission would be redeemed within its redemption window, the best guess of its present value at any point in time would be the expected discounted value for that emission (the solid lines in Figure 3.2). Given that citizens likely could not determine which dollar would be redeemed when within its respective redemption window, the variance in realized values noted above may have been considered only a minor inconvenience. As long as the redemption window for a given emission was relatively short, trade could function relatively smoothly using the expected present value of Continental dollars from the same emission.

More problematic was Congress' choice of staggered sequential redemption windows for subsequent emissions. Congress spread the redemption of subsequent emissions successively forward in time to maintain the fiscal credibility of redemption. By contrast, if Congress would have chosen the proposed alternative of having all new emissions redeemed in the same redemption window, the required redemption taxes would have been beyond historically feasible and acceptable limits, making redemption doubtful. The tradeoff of not choosing this proposed alternative was to make the Continental dollar an even more cumbersome medium of exchange than what it already was for each separate emission.

Figure 3.2 illustrates this problem. Emissions \#1 and \#2 have different expected present values at each point in time. For example, in 1777, the expected present value of a Continental 
dollar from emission \#1 was 81 percent, whereas for emission \#2 it was 64 percent, of its face value. In other words, Continental dollars from different emissions, in effect, were different monies. Citizens would have to use the dates printed on the bills to determine what expected present value to assign to each particular bill of the same denomination. Such values varied by the dates on the bills. Each new emission multiplied this problem, making for an increasingly cumbersome medium of exchange. The Continental dollar could still function as a medium of exchange, but it would necessitate citizens' pricing goods and services separately by Continental dollar emissions (by the dates on bills), and trading Continental dollars from different emissions at values other than one-to-one, namely at their expected present value differential at each point in time.

The cumbersomeness of the Continental dollar's medium-of-exchange function may not have been a concern to Congress, at least pre-1777, or viewed as a costly tradeoff for establishing a fiscally credible redemption structure, because Continental dollars were not expected to be used extensively as a medium of exchange. Congress may have expected most citizens who received Continental dollars to hold them for future redemption, namely hold them as bonds. Early on, this may have been particularly true given that the primary recipients of Continental dollars were soldiers. For example, on 6 August 1779, General Parsons explained,

I have not concerned myself with Commerce to increase my Estate Since the War... I...collected my dues [army salary] in Bills [Continental dollars] at their nominal Value in full Confidence...that at Some future Period my Country would do that Justice which they had promis'd me by paying their Debt at the nominal Value of the Bills they had emitted ...to render old age free from those miseries arising from Indigence... If my Country fails to Support her Independence, I shall be happy in possessing Nothing, but my Life. ${ }^{17}$

The denominational size and spacing of Continental dollar emissions were consistent with their not being expected to be easily used as a medium of exchange. Table 3.3 shows that

\footnotetext{
${ }^{17}$ PCC (m247, r179, i161, pp. 339-41) “Samuel H. Parsons to John Jay (Camp in the Highland), 6 August 1779." The clauses are slightly reordered to improve clarity. See also, Puls (2008, p. 187); Smith (1986, v. 13, p. 388).
} 
Table 3.3 Paper Currency Pyramids: Volume and Face Value of Units Issued by Denomination

\begin{tabular}{|c|c|c|c|c|c|c|c|c|c|c|}
\hline \multicolumn{2}{|c|}{$\begin{array}{l}\text { Continental } \\
\text { Paper Dollar } \\
\text { Denominations }\end{array}$} & \multicolumn{3}{|c|}{$\begin{array}{l}\text { Continental Dollar: } \\
\text { First } 2 \text { Emissions } \\
\text { (All in 1775) }\end{array}$} & \multicolumn{3}{|c|}{$\begin{array}{l}\text { Continental Dollar: } \\
\text { Next } 3 \text { Emissions } \\
\text { (All in 1776) }\end{array}$} & \multicolumn{3}{|c|}{$\begin{array}{l}\text { Comparison with } \\
\text { U.S. Dollar Paper } \\
\text { Currency in } 1990^{\mathrm{C}}\end{array}$} \\
\hline \multirow{5}{*}{\multicolumn{2}{|c|}{$\begin{array}{l}\mathrm{PV}= \\
\text { Average } \\
\text { Expected } \\
\text { Present Value } \\
\text { in Nov. } 1775^{\mathrm{a}}\end{array}$}} & \multirow{2}{*}{\multicolumn{2}{|c|}{$\begin{array}{r}\$ 6 \text { million in: } \\
\text { Face }\end{array}$}} & \multirow{5}{*}{$\begin{array}{l}\mathrm{PV}= \\
\text { in } \\
\text { Nov. } \\
1776^{\mathrm{a}}\end{array}$} & \multicolumn{2}{|c|}{ \$19 million in: } & \multirow{2}{*}{$\begin{array}{l}\text { Approximate } \\
\text { Face-Value }\end{array}$} & \multirow{3}{*}{\multicolumn{2}{|c|}{ Units }} & \multirow{5}{*}{$\begin{array}{l}\text { Value } \\
\text { Issued } \\
\%\end{array}$} \\
\hline & & & & & & Face & & & & \\
\hline & & Units & Value & & Units & Value & Equivalence of & & & \\
\hline & & Issued & Issued & & Issued & Issued & 1775-1776 Bills & & Issued & \\
\hline & & $\%$ & $\%$ & & $\%$ & $\%$ & in 2012 Values & & $\%$ & \\
\hline$\$ 1 / 6$ bill & & 0.0 & 0.0 & $\$ 0.1$ & 10.8 & 0.5 & $\$ 5.2$ bill & $\$ 1$ bill & 37.8 & 1.9 \\
\hline$\$ 1 / 3$ bill & & 0.0 & 0.0 & $\$ 0.1$ & 10.8 & 1.0 & $\$ 10.3$ bill & $\$ 5$ bill & 9.6 & 2.4 \\
\hline$\$ 1 / 2$ bill & & 0.0 & 0.0 & $\$ 0.2$ & 10.8 & 1.6 & $\$ 15.5$ bill & & & \\
\hline$\$ 2 / 3$ bill & & 0.0 & 0.0 & $\$ 0.3$ & 10.8 & 2.1 & $\$ 20.7$ bill & $\$ 10$ bill & 9.6 & 4.7 \\
\hline$\$ 1$ bill & $\$ 0.6$ & 12.0 & 2.2 & $\$ 0.4$ & 4.9 & 1.4 & \$31 bill & $\$ 20$ bill & 25.9 & 25.7 \\
\hline$\$ 2$ bill & $\$ 1.3$ & 12.0 & 4.4 & $\$ 0.8$ & 7.7 & 4.5 & $\$ 62$ bill & & & \\
\hline$\$ 3$ bill & $\$ 1.9$ & 12.0 & 6.6 & $\$ 1.3$ & 7.7 & 6.7 & $\$ 93$ bill & $\$ 50$ bill & 5.2 & 12.6 \\
\hline$\$ 4$ bill & $\$ 2.6$ & 12.0 & 8.8 & $\$ 1.7$ & 7.7 & 8.9 & $\$ 124$ bill & & & \\
\hline$\$ 5$ bill & $\$ 3.2$ & 12.0 & 11.0 & $\$ 2.1$ & 6.5 & 9.4 & \$155 bill & & & \\
\hline$\$ 6$ bill & $\$ 3.9$ & 12.0 & 13.2 & $\$ 2.5$ & 6.5 & 11.3 & $\$ 186$ bill & & & \\
\hline$\$ 7$ bill & $\$ 4.5$ & 12.0 & 15.4 & $\$ 2.9$ & 6.5 & 13.2 & $\$ 217$ bill & $\$ 100$ bill & 10.4 & 52.3 \\
\hline$\$ 8$ bill & $\$ 5.1$ & 12.0 & 17.7 & $\$ 3.3$ & 6.5 & 15.1 & $\$ 248$ bill & & & \\
\hline$\$ 20$ bill & $\$ 12.9$ & 1.0 & 3.9 & $\$ 8.3$ & 0.0 & 0.0 & $\$ 620$ bill & & & \\
\hline \multirow[t]{2}{*}{$\$ 30$ bill } & $\$ 19.3$ & 3.0 & 16.4 & $\$ 12.5$ & 2.8 & 24.3 & $\$ 930$ bill & & & \\
\hline & & $100.0 \%$ & $100.0 \%$ & & $100.0 \%$ & $100.0 \%$ & & & $98.5 \%$ & $99.6 \%$ \\
\hline
\end{tabular}

Sources and Notes: JCC (v. 2, pp. 103, 105, 207; v. 3, pp. 398, 407, 457-8; v. 4, pp. 157, 164-5, 339-40, 374, 380-3; v. 5, pp. 599, 651); Newman (1997, pp. 58-63; 2008, pp. 62-73); Table 3.4. U.S. currency today includes fractional dollars in the form of token coins that facilitate making change. No fractional dollar coins, actually no coins at all, were issued in Continental dollars. Thus, the currency pyramid contrast between current U.S. money and Continental dollar money is more accentuated than that presented in the table here for just paper money.

${ }^{\text {a }}$ Evaluated at 6 percent continuous discount from the average of the expected final redemption. See fn. 16.

${ }^{b}$ From http://eh.net "measuring worth—relative value of U.S. Dollars" using the 1775 to 2012 CPI conversion algorithm.

${ }^{\mathrm{c}}$ Federal Reserve, http://www.federalreserve.gov/paymentsystems/coin/data.htm.

Continental dollars were large-valued bills. The smallest emitted in 1775 was a $\$ 1$ bill, equivalent in face value and expected present value to \$31 and \$21 in 2012 dollars, respectively. Some relative sense of the contemporary value of one Continental dollar can be taken from Congress' payment of $\$ 1$ per week in 1775 to cover an enlisted man's entire weekly subsistence expense while waiting in quarters post-recruitment to join the Continental army. ${ }^{18}$ Over 60

${ }^{18}$ JCC (v. 3, pp. 289, 309, 322, 415, 419). 
percent of the bills emitted in 1775, in face value and expected present value, were equivalent to, or larger than, \$124 and \$86 in 2012 dollars, respectively. Large currency denominations were difficult to use as a medium of exchange. Transactions that required change could not be made unless change was given in some other medium. Fractional Continental dollars were only issued in emission \#3, early in 1776, and never again thereafter. When Congress asked the states on 22 November 1777 to stop emitting their own paper monies, they specifically exempted small denomination state paper monies, recognizing that such was needed to make change. ${ }^{19}$

Soldiers' pay absorbed nearly half of all Continental dollars emitted through 1777 (Grubb 2011b, pp. 273-5). American army privates were paid $\$ 80$ per year. Privates were the primary recipients of military pay, receiving 78 percent of the money paid to each military company. British army privates were paid $\$ 55$ per year. American privates were paid in paper Continental dollars, whereas British privates were paid in specie. In November 1775, the expected present value of 80 Continental dollars of the first emission was between $\$ 63$ and $\$ 53$, or comparable with the present value of a British private's yearly pay. Relative to privates' pay, the pay of upper ranks increased less in the American than in the British army. Thus, by-rank comparisons above private are less informative. ${ }^{20}$ That Congress initially set an American army private's pay to be equal to a British army private's pay in expected present value terms rather than in face value terms is an acknowledgement by Congress of the zero-interest bearer bond nature of the Continental dollar that it was creating.

The unconventional denominational structure of Continental dollar emissions was also

\footnotetext{
${ }^{19}$ JCC (v. 7, p. 125; v. 9, pp. 955-6); Newman (1997, pp. 58-69, 106-10, 121-3, 170-4, 202-11, 235-40, 255-9, 2817, 347-56, 390-6, 415-22, 440-51); Smith (1979, v. 4, p. 88).

${ }^{20}$ Derived from Fortescue (1910-30, v. 4, pt. 2, p. 935); JCC (v. 2, pp. 89-90, 93-4, 209-10, 220-3; v. 3, pp. 322-3, 384, 417, 427; v. 11, pp. 539-43); Pennsylvania Gazette (14 August 1776); Smith (1978, v. 3, pp. 588-9); Williamson (1796, p. 27); and http://footguards.tripod.com/01ABOUT/01_payscale.htm [accessed 30 January 2013]. Currency conversions are from McCusker (1978, p. 10).
} 
consistent with Congress' intending to pay soldiers in large bills that would be held for future redemption, rather than spent as currency. Throughout the American colonies, as well as in modern economies, currency denominations were typically spaced by factors of two, three, or five, and in a pyramid structure with more units in the lower than in the higher denominations. These features reduced the transaction costs of using that money as a medium of exchange in terms of making change. Table 3.3 shows that the denominational structure of the Continental dollar did not have these features. ${ }^{21}$

The unusual denominational structure of the Continental dollar becomes sensible if Congress' intent was to pay soldiers in the fewest bills necessary, and thus in large-valued bills that were not intended to circulate easily as currency. Three months pay for a private, $\$ 20$, could be accommodated with one or various combinations of three, four, or five large-valued bills. One month's pay for a private after clothing deductions, $\$ 5$, could be accommodated with one or various combinations of two large-valued bills. For higher ranked military personal, paying them with a few large-valued bills was even easier.

Soldiers' pay was fixed by Congress in nominal terms in June and July of 1775. As the war continued, the present value of soldiers' pay when made in subsequent emissions fell. In November 1775, the expected present value of a full year's pay for an American private, when paid with dollars from the second emission, would be between $\$ 50$ and $\$ 41$ - below the present value of a British private's yearly pay. For subsequent emissions, it was even lower. In effect, Congress was financing the war by systematically reducing the real pay of its citizen soldiers and increasingly so as the war progressed. The necessity of Congress to adjust nominal military pay to realign it with the new present value of each successive emission of Continental dollars may

${ }^{21}$ See $J C C$ (v. 2, pp. 220-3; v. 3, pp. 322-3); Newman (1997, 2008); Sparks (1832, v. 1, p. 273); Telser (1995); Van Hove (2001). 
have been overlooked or just deemed too complicated to constantly address. Keeping the pay structure of the military fixed in the nominal values as set before August 1775 made it both easier for Congress to estimate and budget military expenses, as well as finance the war via military-pay price controls.

This action, however, created problems for the financing system regarding military pay over a long war. At some point, soldiers would no longer re-enlist and fight for a fraction of the present value of their original pay. Late in the war, Congress moved to solve this problem by promising military personnel that Congress would make up "the deficiency of their original pay" when feasible. $^{22}$ This promise is consistent with Congress' acknowledging the zero-interest bearer bond design of the Continental dollar monetary system it had created, along with its declining present value as new emissions pushed redemption farther into the future.

\section{DID THE PUBLIC KNOW? WERE THEY INFORMED?}

Congress' redemption instructions for the first and second emissions were widely disseminated. Congress circulated a handbill that contained its Continental dollar resolutions passed before 30 July 1775, including all the relevant redemption provisions for the first emission, see Figure 3.3. This handbill was reprinted in its entirety in numerous newspapersthe first being in the Connecticut Journal, \& New-Haven Post-Boy, 25 October 1775. Between 25 October and 4 December 1775 all three newspapers in Connecticut, three of the four in Massachusetts, one of the two in Rhode Island, one of the four in New York, and two of the five in Pennsylvania reprinted it. Out of the surviving newspapers consulted, 10 of 24 reprinted the

\footnotetext{
22 See fn. 20; JCC (v. 15, p. 1335; v. 16, p. 344; v. 19, p. 413); Puls (2008, pp. 174-6, 181); Smith (1982, v. 9, pp. 326, 691; 1986, v. 13, pp. 139, 296, 414; 1988, v. 15, pp. 24, 29, 31, 56).
} 
In Congrefs, Thurfday, June 22, 1775.

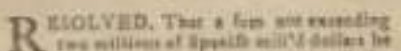

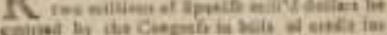

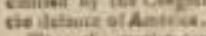

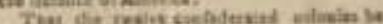

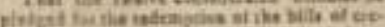

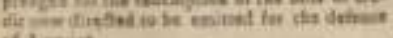
if $\mathrm{s}=\mathrm{min}$

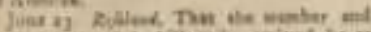

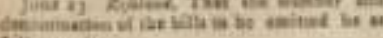
Filion, via.

thenoo kifa of I dal eath ysa bee

noveris 34t. 341000

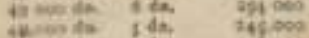

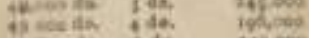

theos to ids Whe

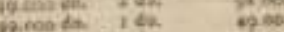

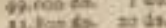

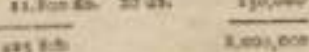

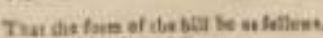

N Cieinatal Comons.

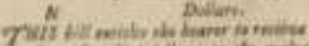

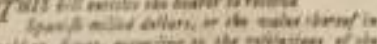

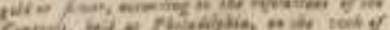

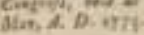

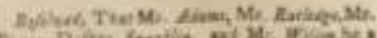

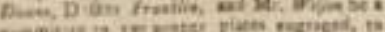

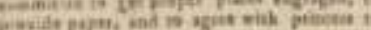

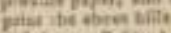

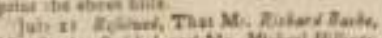

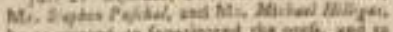

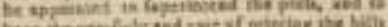

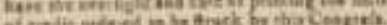
frevile

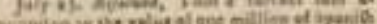

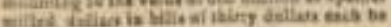
aminastion

Ar the froing ha grest somber of billu

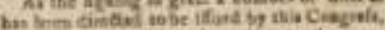

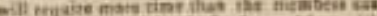

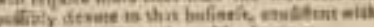

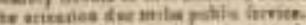

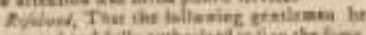

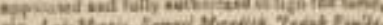
is. Lair

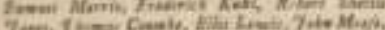

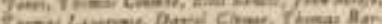

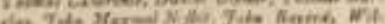

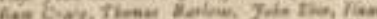

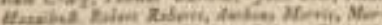

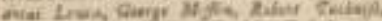

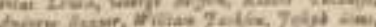

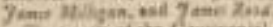

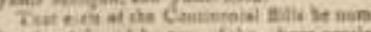

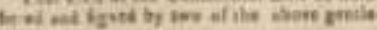
Enit.

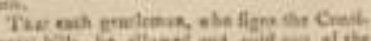

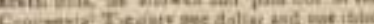

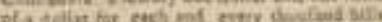
Wived and asebeed by fin.

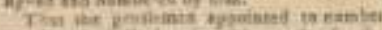

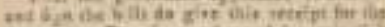

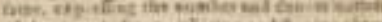

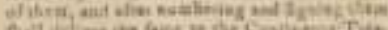

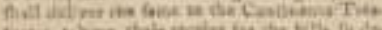

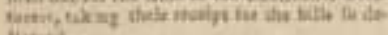

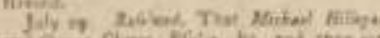

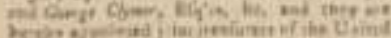
Cols.

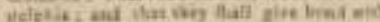

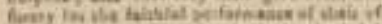

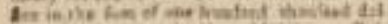

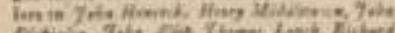

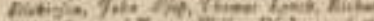

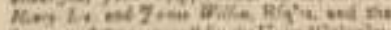

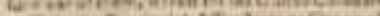

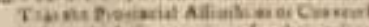

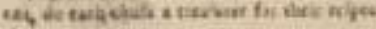

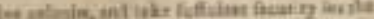

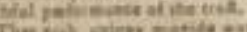

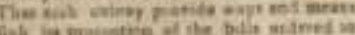

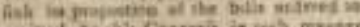

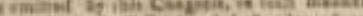

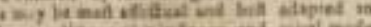

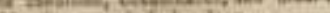

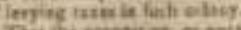

cat he peoper in er quitu of test cole-

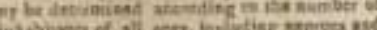

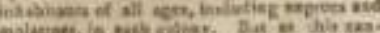

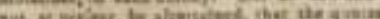

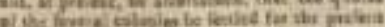

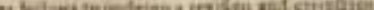

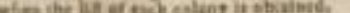

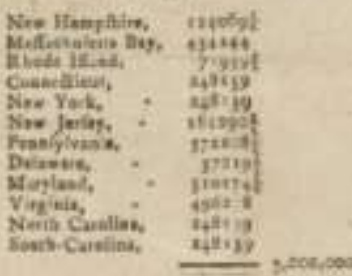

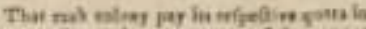

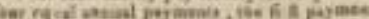

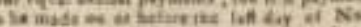

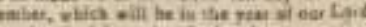

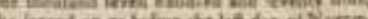

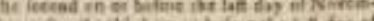

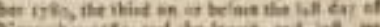

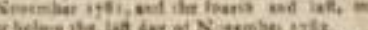

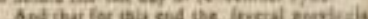

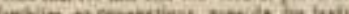

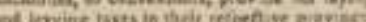

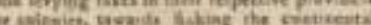

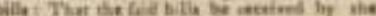

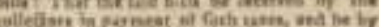

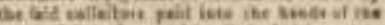

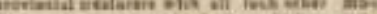

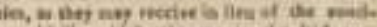

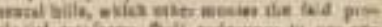

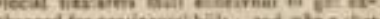

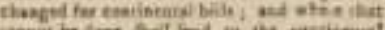

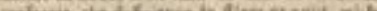

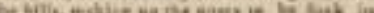

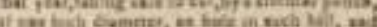

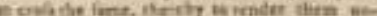

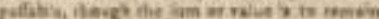

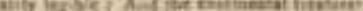

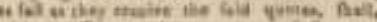

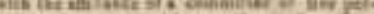

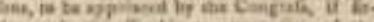

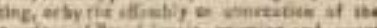

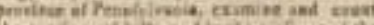

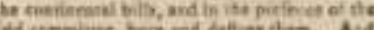

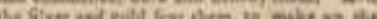

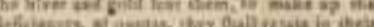

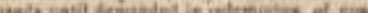

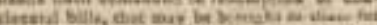

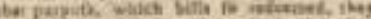

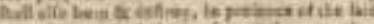

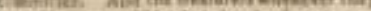

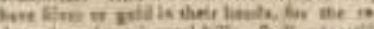
chay

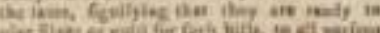

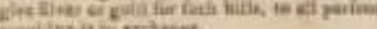

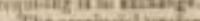

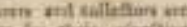

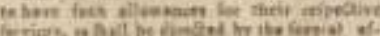

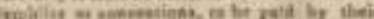

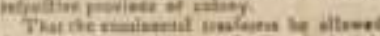

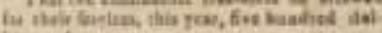
tan caeh

$$
\text { Ant fine it nimin: }
$$

Charles Thompfon, Seciry. 


\section{Figure 3.3 Handbill Issued by Congress Informing the Public of the Design and Redemption Structure of the First Emission of Continental Dollars, Circa August-October 1775}

Source: United States, Continental Congress (Philadelphia?: s.n. 1775)

http://memory.loc.gov/service/rbc/bdsdcc/00301/0001.jpg [accessed 30 January 2013].

handbill. ${ }^{23}$ The redemption procedures covering the second emission were reprinted in The

Pennsylvania Evening Post, 12 March 1776. This information was also disseminated when

Congress published its journals at the end of 1775 and later in $1776 .{ }^{24}$ Between the direct

circulation of the handbill, the reproduction of it in the nation's newspapers, publication of

Congress' journal, and publication of congressional resolutions in The Pennsylvania Evening

Post, the public was well informed, with the possible exception of citizens in the Southern

colonies, of the Continental dollar's structural design and redemption procedures.

The distinct bearer-bond nature of the Continental dollar could be gleaned from what was

23 See Grubb (2012a, pp. 151-2). During 1775, the handbill was reprinted in its entirety in the Connecticut Journal, \& New Haven Post-Boy, New Haven, CT on October 25; in The Pennsylvania Evening Post, Philadelphia, PA on November 2; in the Pennsylvania Ledger or the Virginia, Maryland, Pennsylvania, \& New Jersey Weekly Advertiser, Philadelphia, PA on November 4; in the Connecticut Courant and Weekly Intelligencer, Hartford, CT on November 6; in the Norwich Packet and the Connecticut, Massachusetts, New-Hampshire, and Rhode Island Weekly Advertiser, Norwich, CT on November 6; in the New-York Journal; or, The General Advertiser, New York, NY on November 9; in Thomas's Massachusetts Spy or, American Oracle of Liberty, Worcester, MA on November 10; in the Providence Gazette and Country Journal, Providence, RI on November 11; in The New-England Chronicle or The Essex Gazette, Cambridge, MA on November 16; and in The Boston Gazette and Country Journal, Watertown, MA on December 4. The newspapers consulted where no evidence could be found that the handbill was reprinted therein are: The New-Hampshire Gazette and Historical Chronicle (Portsmouth, NH); Freeman's Journal (Portsmouth, NH); The Essex Journal and Merrimack Packet: The Massachusetts and New-Hampshire General Advertiser (Newburyport, MA); The Newport Mercury (Newport, RI); The Constitutional Gazette (New York, NY); New-York Gazette and the Weekly Mercury (New York, NY); Rivington's New-York Gazette; Or, The Connecticut, Hudson's River, New Jersey, and Quebec Weekly Advertiser (New York, NY); Pennsylvania Gazette (Philadelphia, PA); Dunlap's Pennsylvania Packet or the General Advertiser (Lancaster, PA); The Pennsylvania Journal; and The Weekly Advertiser (Philadelphia, PA); Maryland Gazette (Annapolis, MD); Virginia Gazette (Williamsburg, VA); South-Carolina Gazette; and Country Journal (Charleston, SC); and The South-Carolina Gazette (Charleston, SC). Because the newspapers consulted did not have a complete run of surviving copies or had terminated early in this period, the ratio of those reprinting the handbill out of the total newspapers consulted is biased low.

${ }^{24}$ For congressional discussions about publishing their proceedings, see JCC (v. 2, p. 208; v. 3, pp. 263-4, 393, 427, 431); Smith (1976, v. 1, pp. 503, 525-6, 695; 1980, v. 6, p. 404; 1986, v. 13, p. 383; 1988, v. 15, p. 484). The Constitutional Gazette, 20 December 1775; New-York Gazette and the Weekly Mercury, 25 December 1775; NewYork Journal; or, The General Advertiser, 21 December 1775; The Pennsylvania Journal; and the Weekly Advertiser, 13 December 1775; and the Pennsylvania Gazette, 23 October 1776 advertised the proceedings of the Continental Congress for sale. 
printed on the face of each bill, namely "This Bill entitles the BEARER to receive [AMOUNT ON BILL] Spanish MILLED DOLLARS, or the Value thereof in Gold or Silver, according to a Resolution of CONGRESS passed at Philadelphia [date of the authorizing resolution]", (Newman 2008, pp. 37, 63-73). The congressional resolution referred to on the bill laid out the redemption dates when the bearer would receive the Spanish silver dollars, or value thereof, designated on the face of the bill. This language differed from that typically printed on colonial paper monies, New Jersey and post-1766 Maryland excepted, which indicated that colonial bills were intended to be used more as current money than long-term bonds, namely "This BILL by $L A W$ shall pass current in [colony's name], for [the amount printed on the face of the bill]. ${ }^{, 25}$ Language was important and precisely used. Everyone could see and grasp the difference.

Once the public was informed of the Continental dollar's structural design, they acted as if they understood that it was a zero-interest bearer bond requiring time-discounting to ascertain its present value. The first reports of Continental dollars trading below face value appeared before Congress in Philadelphia on 23 November 1775. This event occurred immediately after the structural design of the Continental dollar was first reported in Pennsylvania newspapers. ${ }^{26}$ After the public was told that Continental dollars were zero-interest bearer bonds with defined maturity dates, they started to accept them below their face value.

The first congressional committee to investigate reports of depreciation was formed in November of 1775. It was comprised of John Jay, Benjamin Franklin, Samuel Adams, Thomas Johnson, George Wythe, Edward Rutledge, and Thomas Jefferson. This committee recognized that Continental dollars were being accepted below their face value, but the resolution and published announcements that were adopted did not explicitly condemn such. They only

\footnotetext{
${ }^{25}$ See Grubb (2012b); Newman $(1997,2008)$ [italic and capitalization in the original].

${ }^{26}$ See JCC (v. 3, pp. 367-8, 424, 455; v. 4, pp. 49-50); Pennsylvania Gazette (17 January; 17 and 24 April; 19 June 1776); Smith (1977, v. 2, p. 464); fn. 23.
} 
condemned the non-acceptance of Continental dollars. Not explicitly condemning this

"depreciation," but only condemning non-acceptance, was consistent with Congress recognizing that time-discounting was not really depreciation per se, and that the public was right to accept Continental dollars below their face value given that they were zero-interest bearer bonds. ${ }^{27}$

\section{DESCRIPTIONS BY NATIONAL LEADERS OF THE CONTINENTAL DOLLAR}

Numerous important citizens and national leaders knew about time-discounting and the present-value calculation that reduced a future value to a current value. They explained the Continental dollar as a zero-interest bearer bond needing such discounting to understand its current value. In their descriptions, the Continental dollar was not a pure fiat currency, and timediscounting was not depreciation per se. These ideas were not totally new. Numerous colonial writers had articulated the time-discounting embedded in many colonial paper monies. ${ }^{28}$

Pelatiah Webster, an influential contemporary writer, saw the impact of time-discounting on the Continental dollar almost immediately after its structural design was revealed in the handbill circulated by Congress. In an essay published in the Pennsylvania Evening Post, 5 October 1775, he asked in reference to the Continental dollar, "Why should the soldier, tradesman, farmer, \&c. be paid in promises, which are not so good as money, if fulfilment is at a distance?"29 Webster considered the Continental dollar not to be proper current money because it was a promise to pay money at a future date, namely a bond with a fixed maturity date.

On 19 April 1776 Congress created a committee to ascertain the comparative value of different silver and gold foreign coins. The committee consisted of James Duane, George Wythe, John Adams, Roger Sherman, Joseph Hewes, Thomas Johnson, and William Whipple. Thomas

27 See fn. 26; Smith (1979, v. 4, pp. 295, 424, 678).

${ }^{28}$ For examples, see Davis (1964, v. 1, pp. 384-5v. 2, pp. 314, 318; v. 3, pp. 158-9, 182, 191, 196-8, 247, 430-1, 433, 440, 445, 454, 462, 471; v. 4, pp. 49, 179-80, 185, 223, 386, 398, 401-2); Grubb (2012b); Ricord (1892, v. 17, 159) .

${ }^{29}$ Webster (1969, p. 2). 
Jefferson joined the committee on 24 July 1776. The structural design of the Continental dollar required that Congress rate the relative value of foreign coins. This can be seen by remembering what was printed on the face of each Continental dollar, namely "This Bill entitles the BEARER to receive [AMOUNT ON BILL] Spanish MILLED DOLLARS, or the Value thereof in Gold or Silver, according to a Resolution of CONGRESS passed at Philadelphia [date of the authorizing resolution]. ${ }^{30}$ This language meant that future redemption could be in Spanish silver dollars or its specie equivalent. It is that equivalence in other foreign specie coins that had to be established by Congress. That this task was the sole initial purpose of this 19 April 1776 committee is seldom noted. However, the committee's report, both on 22 May 1776 and 2 September 1776, clearly stated that that was its purpose. ${ }^{31}$ The second paragraph of the committee's report says,

Whereas, the holders of bills of credit [Continental dollars] emitted by authority of Congress will be entitled, at certain periods appointed for redemption thereof to receive out of the treasury of the united colonies the amount of the said bills in spanish milled dollars, or value thereof in gold or silver; and the value of such dollars, compared with other silver and with gold coins, is estimated by different standards in different colonies, whereby injustice may happen in some instances to the public, as well as to individuals which ought to be remedied. ... Therefore,

Resolved, that the several gold and silver coins passing in the said colonies shall be received into the public treasury of the continent, and paid out in exchange for bills emitted by authority of Congress, when the same shall become due, at the rates set down in the following table:

This committee clearly operated with the understanding that Continental dollars would not be redeemed until some future date, and at that date their redemption would be, or could be, in specie coins paid out of the Continental Treasury. In other words, the Continental dollar was a type of bearer bond anchored to face-value specie payments at some future date.

In January of 1778 the Commissioners of the New England states, along with

\footnotetext{
30 See Newman (1997, pp. 59-68; 2008, pp. 37, 63-73), italics and capitalization in the original.

31 See $J C C$ (v. 4, pp. 293-4, 381-3; v. 5, pp. 608, 724-8). The actual quotation is from $J C C$ (v. 4, p. 382). This committee went beyond its mandate and proposed other resolutions that were incoherent and internally inconsistent. These other matters will be addressed in future papers.
} 
Commissioners from New York, Pennsylvania, and New Jersey met in New Haven, Connecticut to discuss economic issues related to the Revolution. In their letter to Congress, 30 January 1778, they concluded with the following observation:

Before we Conclude we beg leave to mention that the public have never yet been notified, when the Continental Bills are to be redeemed, except the two first Emissions. Their being at an uncertainty about this matter has been complained of as having a tendency to lessen the Credit of the bills, Whereas if they were to be Ascertained when they were to be redeemed, Especially if it was at a short period, it would give them a confidence in the money, and greatly tend to Establish its Currency. ${ }^{32}$

The Commissioners' observations were consistent with understanding the Continental dollar to be a zero-interest bearer bond rather than a pure fiat currency. They noted that the time to redemption influenced the value of the bills, with a more distant redemption window being associated with a lower current value. They also noted that Congress had not yet fixed the redemption windows of emissions that came after emission \#2, and so people had to guess or forecast what those redemption windows would be. If they guessed a more distant redemption date, that would lessen the current value of the bills. Therefore, if Congress set a redemption window that was closer to the present, that would raise the current value of the bills.

Roger Sherman was a delegate from Connecticut to the Continental Congress from 1774 through 1781. He was often a member of Congress' finance committees, took an active part in congressional debates on money, and was regarded as knowledgeable about monetary matters. In a letter to the Governor of Connecticut, Jonathan Trumbull, Sr., on 27 October 1778, Sherman gave a clear explanation of the nature of the Continental dollar. He wrote,

A note for $£ 100$ on compound interest, payable at the expiration of 20 years would be equal to one for $£ 321$ for the same term without interest. If the Bills of public credit [Continental dollars], so far as they exceed a sufficient quantity for a medium of trade, are to be considered only as securities for money without interest, rebating the compound interest for the time before they are redeemable will determine their present value, and

\footnotetext{
32 Hammond (1889a, p. 293). The Commissioners offer other observations not wholly consistent or coherent with this last observation. These other observations will be dealt with in future papers.
} 
they will gradually appreciate as time of their redemption approaches. Enclosed is a computation of the annual increase of $£ 100$ for 21 years on compound interest. ${ }^{33}$

Sherman' description of the Continental dollar is that of a zero-interest bearer bond. He views a Continental dollar as a security for money to be delivered in the future without interest paid in the interim, as opposed to money itself. He also describes the time-discounting that must be done to determine a Continental dollar's current value. He even uses the term present value to describe that current value. He also describes the rise, or appreciation, in that value as the time to redemption approaches. In his example, the implied interest rate that discounts $£ 321$ from 20 years in the future to $£ 100$ in the present is 5.83 percent, i.e. $100=321 * e^{(-0.583 * 20)}$. Sherman even provided his correspondent with a table to do time-discounting calculations.

Gouverneur Morris was a delegate to Congress from New York, attending between 20 January 1778 and late November 1779. He was a member of Congress' 1778 committee attempting to reorganize the treasury and sort out the government's currency finance system. He would go on to become a central actor on monetary issues for the U.S. government under Robert Morris when Robert Morris was Superintendent of Finance, and then a key shaper of the monetary provisions in the U.S. Constitution at the 1787 Constitutional Convention. ${ }^{34}$ In the course of working on the 1778 congressional committee's report on currency finance, of which he was the author, he wrote a treatise on money. That committee's report was delivered on 19 September 1778 and was largely shelved by Congress as too controversial. In Morris' preparatory treatise on money, alluding to paper money like the Continental dollar, he reasoned,

If a Legislature...should utter a Paper Medium payable at a distant Day it would or would not be received according to the Want of such Medium among the People. And when received it's Value would depend on the Consideration $1^{\text {st. }}$ of the Want $2^{\text {ly. }}$ of the

\footnotetext{
33 See Smith (1985, v. 11, pp. 136-9, 306-7).

34 Brookhiser (2003, pp. 31-93); Grubb (2003, pp. 1787-90; 2006, pp. 54-64; 2007b, pp. 41-50;); JCC (v. 11, pp. 731, 779-87; v. 12, pp. 929-33); Sparks (1832); Smith (1981, v. 7, p. xviii; v. 8, p. xx; 1982, v. 9, p. xx; 1983, v. 10, p. xx; 1985, v. 11, p. xxi; v. 12, p. xx; 1986, v. 13, p. xx; 1987, v. 14, p. xxi).
} 
Distance of the Day of Payment $\& 3^{\text {ly. }}$ of the Certainty or Uncertainty of such Payment. ${ }^{35}$ Gouverneur Morris viewed the value of paper money, such as the Continental dollar, as being determined by: (1) the preference or liquidity premium attached to that money compared with its next best alternative, i.e. the "Want"; (2) the time to redemption, i.e. time-discounting; and (3) the fiscal credibility of the future promised payment. Therefore, if no excess preference or liquidity premium existed and future redemption was certain, then the present value of a Continental dollar would depend only on time-discounting, i.e. the Continental dollar was a zerointerest bearer bond. Morris saw the credibility of the government's promise of a future money payoff, namely the government's will and ability to meet that payoff at the time of redemption, along with the time to redemption, as key determinants of the present value of the Continental dollar. It is hard to interpret this passage without saying that Morris understood the Continental dollar, at least potentially, to be a zero-interest bearer bond and not a fiat currency.

James Madison was elected to Congress on 14 December 1779. To prepare for this role, he studied the finances of the United States and, sometime between 14 December 1779 and 18 March 1780, wrote down his thoughts. While these observations — his treatise on money—would not be published until 1791, it seems unlikely that he wrote in a vacuum. Fellow Virginians familiar with the history of congressional paper money emissions were likely consulted by Madison before he made his way to Philadelphia. If so, his observations may reflect some consensus beyond the reasoning of just one man. Madison's treatise on money is the most clear, consistent, and cogent analysis of the nature and structural design of the Continental dollar written by any American during, or in the decade after, the Revolution, including anything written by the financial luminaries of the American Revolution, namely Benjamin Franklin,

\footnotetext{
35 Barlow (2012, pp. 73, 75). Gouverneur Morris' analysis of money involves alternatives that are inconsistent with the passage quoted here. These alternatives will be taken up in future papers.
} 
Alexander Hamilton, Gouverneur Morris, Robert Morris, and Pelatiah Webster. Madison's entire

treatise is recommended reading. A brief portion highlighting the zero-interest bearer-bond

nature of the Continental dollar follows:

If the circulating medium be a municipal one, as paper currency....

It consists of bills or notes of obligation payable in specie to the bearer, either on demand or at a future day. [Madison indicates that for the illustrative exercise to follow, the credibility of redemption whether on demand or at a fixed future day will always be assumed.] Of the first kind is the paper currency of Britain [banknotes], and hence its equivalence to specie. Of the latter kind is the paper currency of the United States [the Continental dollar], and hence its inferiority to specie.

Let us suppose that the circulating notes...instead of being payable on demand, were to be redeemed at a future day, at the end of one year for example, and that no interest was due them. ... They would in that case represent not the nominal sum expressed on the face of them, but the sum remaining after a deduction of one year's interest. ... We may extend the time from one, to five, or to twenty years; but we shall find no other rule of depreciation than the loss of the intermediate interest.

[The United States] Being engaged in a necessary war without specie to defray the expense, or to support paper emissions for that purpose redeemable on demand, and being at the same time unable to borrow, no resource was left, but to emit bills of credit [Continental dollars] to be redeemed in the future. The inferiority of these bills to specie was therefore incident to the very nature of them. If they had been exchangeable on demand for specie, they would have been equivalent to it; as they were not exchangeable on demand, they were inferior to it. The degree of their inferiority must consequently be estimated by the time of their becoming exchangeable for specie, that is the time of their redemption.

Suppose the period necessary for its [the Continental dollar's] redemption to be 18 years, as seems to be understood by Congress; ${ }^{36} 100$ dollars of paper 18 years hence will be equal in value to 100 dollars of specie; for at the end of that term, 100 dollars of specie may be demanded for them. They must consequently at this time be equal to as much specie as, with compound interest, will amount, in that number of years, to 100 dollars. ... Admit, however the use of money to be worth 6 per cent. about 35 dollars will then amount in 18 years to 100.35 dollars of specie therefore is at this time equal to 100 of paper; that is, the man who would exchange his specie for paper at this discount, and lock it in his desk for 18 years, would get 6 per cent. for his money. ${ }^{37}$

Madison explained the difference between a paper currency convertible to specie at face

value on demand versus one convertible to specie at face value but only at some future date.

\footnotetext{
${ }^{36}$ Madison is referencing Congress' 2 and 14 January 1779 resolutions on the redemption of the Continental dollar, see Table 3.1.

${ }^{37}$ Hutchinson and Rachel (1962, v. 1, pp. 304-5, 308, 310). Madison's treatise on money was published in the National Gazette on 19 and 22 December 1791. I thank Alan Gibson for bringing Madison's treatise to my attention.
} 
Assuming certainty of convertibility, the one convertible on demand will circulate at its face value because it is equal at any point in time to its face value in specie. But even assuming certainty of redemption, the present value of the one convertible at some future date, by its very nature, will not equal its face value, but only its face value reduced by time-discounting from the future date of redemption. Madison even gives an example of what the value of 100 Continental dollars redeemed in 18 years for 100 silver dollars would be today at a 6 percent discount rate, namely 35 silver dollars. Madison terms this reduced value "depreciation," but means only the loss of interest, not depreciation per se or a loss of principal at redemption. He also concludes that its present value is governed by the time-span to redemption. The further into future is the promised redemption, the lower must be the present value. As such, Madison does not mean depreciation as everyone else used the term for there was no loss in value separate from timediscounting. Madison also notes the importance of, and even uses the phrase, "credibility of redemption" for determining a Continental dollar's present value. Future redemption based on levied taxes had to be fiscally possible, a burden able to be sustained by the public, to prevent depreciation beyond time-discounting. Madison understood Continental dollars, by the "incident to the very nature of them," to be zero-interest bearer bonds, and not pure fiat currency.

Lastly, on 17 February 1780, Gouverneur Morris, who was out of Congress and working as a lawyer in Philadelphia at the time, published an analysis of America's finances in the Philadelphia newspaper Pennsylvania Packet, or General Advertiser, he ended with the following observation,

I have spoken of paper [money] hitherto without marking particularly the effects which follow from the idea of redemption. But now let us advert for this purpose to our paper [the Continental dollar]. Suppose a full confidence prevailed that in twenty years it would be appreciated to its nominal value; then every man possessed of forty dollars 
would believe that if he kept it twenty years it would be worth forty dollars in specie. ${ }^{38}$ Now if we reckon a compound interest of six per cent. forty dollars payable twenty years hence will be worth at present about twelve and a half, which deducting two and a half leaves ten. Wherefore it would follow, that he who purchases paper [Continental dollars] at the rate of four for one, would have the best possible security to receive a compound six per cent. interest on his money, with an ultimate additional profit of twenty-five per cent. at the end of twenty years. ${ }^{39}$

As with Gouverneur Morris’ passage quoted earlier, Morris treats the Continental dollar here as a zero-interest bearer bond and not a pure fiat currency. Its present value, under the ideal condition of being paid off in the future with certainty, is determined only by time-discounting. He goes on to give an example using 6 percent as the discount factor and 20 years as the time to redemption. He calculates that $\$ 40$ at face value in 20 years is only worth $\$ 12.5$ today. He does not call this lower present value today depreciation. It is just time-discounting.

James Madison, Gouverneur Morris, Roger Sherman, Pelatiah Webster, the Commissioners attending the January 1778 New Haven Conference, and the 1776 congressional committee that rated foreign coins, i.e. James Duane, George Wythe, John Adams, Roger Sherman, Joseph Hewes, Thomas Johnson, William Whipple, and Thomas Jefferson, all explicitly articulated an understanding of the Continental dollar consistent with its being a zerointerest bearer bond and not a pure fiat currency. Why that understanding was forgotten, even by most of those listed above, and then by everyone else, and why it was supplanted and displaced by the traditional historiography that views the Continental dollar as just another fiat currency, will be addressed in future papers.

\section{FORECASTING THE REDEMPTION OF EMISSIONS \#3 THROUGH \#10}

For the first two emissions Congress issued timely redemption instructions. For the next

\footnotetext{
38 Morris was referencing to Congress' most recent resolutions that of 2 and 14 January 1779, which set redemption of the Continental dollar to run to 1797, see Table 3.1.

39 Barlow (2012, pp. 103, 109-10). Gouverneur Morris’ analysis of money involves alternatives that are inconsistent with the passage quoted here. These alternatives will be taken up in future papers.
} 
eight emissions (emissions \#3 through part of emission \#10, totaling $\$ 95,500,300$ in face value), Congress issued no explicit redemption instructions. At best, statements were made indicating that redemption would be "on the same security as the sums of money heretofore emitted by Congress have been," "in such manner...as Congress shall hereafter direct," and for "periods...that shall be fixed by Congress." But most often nothing was stated. After 1775, Congress shifted monetary matters from Congress, sitting as a whole, to standing subcommittees. Redemption instructions for subsequent emissions fell between these administrative cracks, each group apparently thinking the other was responsible for establishing the redemption instructions for new emissions. Not until emission \#11 did Congress sitting as a whole resolve this administrative oversight. ${ }^{40}$

This failure by Congress to explicitly give redemption instructions for emissions \#3 through part of \#10 was noticed, and the fact that everyone was "left to his own conjectures" as to when redemption would occur was a concern. James Madison, in his treatise on money, explicitly stated this concern and described the likely forecast that was made,

Every one must have taken notice that, in the emissions of Congress, no precise time has been stipulated for their redemption, nor any specific provision made for that purpose. A general promise entitling the bearer to so many dollars of metal as the paper bills express, has been the only basis of their credit. Every one therefore has been left to his own conjectures as to the time the redemption would be fulfilled; and as every addition made to the quantity in circulation, would naturally be supposed to remove to a proportionally greater distance the redemption of the whole mass, it could not happen otherwise than that every additional emission would be followed by a further depreciation [meaning by depreciation a lower present value due to time-discounting]. ${ }^{41}$

The January 1778 meeting of state commissioners in New Haven also noted the lack of redemption instructions for these emissions. In their letter to Congress, they concluded, ...the public have never yet been notified, when the Continental Bills are to be redeemed,

\footnotetext{
40 See Table 3.1; JCC (v. 4, pp. 156-7); Smith (1978, v. 3, pp. 270-1).

${ }^{41}$ Hutchinson and Rachal (1962, pp. 305-6).
} 
except the two first Emissions. ... if they were to be Ascertained when they were to be redeemed, Especially if it was at a short period, it would give them a confidence in the money, and greatly tend to Establish its Currency. ${ }^{42}$

They noted that the distance to redemption was critical, and so what the public conjectured about redemption-distance was important to determining the current value of Continental dollars.

By necessity, therefore, the pattern of redemption for these eight emissions (\#3 through part of \#10) was being forecasted by the public. What a rational forecast would be is constructed using the redemption pattern set by Congress for the first two emissions of Continental dollars, those issued in 1775, and expectations based on how the colonies had financed the French and Indian War. This was information the public had. Therefore, it would likely form the basis of any forecast the public made of the unspecified redemption structure for the next eight emissions of Continental dollars, i.e. those issued from 1776 through 1778. In general, redemption would only start post-war and would be pushed successively into the future with each subsequent emission. It would also be spread over enough years to keep tax levels within historically acceptable and feasible limits, thus giving the system fiscal credibility.

Three forecasts are consistent with the redemption pattern set by Congress in 1775 . First, a four-year contiguous redemption interval would be maintained for each subsequent emission starting the year after the redemption interval for the immediately prior emission ended (Forecast 1). Second, redemption intervals would be adjusted to maintain a constant per year per whitecapita tax level until all emissions were redeemed at face value, with $\$ 0.33$ being that level (Forecast 2). Third, redemption intervals would be adjusted to maintain a constant $\$ 750,000$ per year redemption amount until all emissions were redeemed at face value (Forecast 3). Forecast 1 is identical to Forecast 3 when emission sizes are identical, which is approximately true for

\footnotetext{
42 Hammond (1889a, p. 293).
} 
emissions \#1 through \#7. After emission \#7, emission sizes get so large that by 1779 Forecast 3 would entail a redemption period of 267 years. As such, Forecast 3 is redundant before and unrealistic after 1777, and so is not used. Forecast 2 requires making population growth projections. That such projections were made regarding the redemption of Continental dollars can be seen in John Jay's published address to the public as President of Congress on 13 September 1779. ${ }^{43}$ The construction of Forecast 2 uses estimates of the actual growth in population. Both Forecasts 1 and 2 are used to represent the public's expectations about future redemptions of Continental dollars.

Table 3.4 presents the ideal expected present value of a Continental dollar at each emission's inception as a percentage of its face value based on face-value redemption dates, both legislated and forecasted, using a 6 percent discount (interest) rate. ${ }^{44}$ Ideal means with certainty regarding the promise of redemption at face value and with 6 percent being the average timepreference or market opportunity cost of comparable investments. The third column calculates the expected present value at inception, and Figure 3.4 draws the full ideal expected present value time-paths from inception to redemption, for emissions \#1 through \#7, using legislated redemption instructions for emissions \#1 and \#2 and Forecast 1 for emissions \#3 through \#7. Each emission starts at an expected present value well below its face value due to timediscounting and then rises to its face value by its last redemption date. Because each new emission is forecast to have a four-year redemption window staggered successively forward in time, each emission's ideal expected present value time-path is positioned successively farther to the south and east in Figure 3.4. This is not depreciation per se, but merely time-discounting. While each emission's ideal expected present value time-path is rising over time, the

\footnotetext{
${ }^{43} J C C$ (v. 15, p. 1056).

${ }^{44}$ See fn. 16.
} 
Table 3.4 Legislated/Forecasted Redemption Dates and Valuations for Continental Dollar Emissions

\begin{tabular}{|c|c|c|c|c|c|c|c|c|c|}
\hline \multirow{3}{*}{$\begin{array}{l}\qquad(1) \\
\text { Emission \# } \\
\text { Date Printed } \\
\text { on the Bills: } \\
\text { (Amount) }\end{array}$} & (2) & (3) & \multicolumn{2}{|c|}{$\begin{array}{c}(4) \\
\text { Average }\end{array}$} & \multicolumn{4}{|c|}{$\begin{array}{c}\text { (5) } \\
\text { Under Legal Tender Laws: }\end{array}$} & Implied \\
\hline & $\begin{array}{l}\text { Maturity/ } \\
\text { Redemption } \\
\text { Interval }\end{array}$ & $\begin{array}{l}\text { Expected } \\
\text { Present } \\
\text { Value }\end{array}$ & \multicolumn{2}{|c|}{$\begin{array}{l}\text { Value to Date } \\
\text { [Legislated] } \\
\text { Forecasts }\end{array}$} & \multicolumn{2}{|c|}{$\begin{array}{l}\text { Expectations } \\
\text { Forecasts }\end{array}$} & $\begin{array}{l}\text { No Fo } \\
\text { Expec } \\
\text { Fore }\end{array}$ & $\begin{array}{l}\text { resight } \\
\text { tations } \\
\text { ecasts }\end{array}$ & $\begin{array}{l}\text { Average } \\
\text { Tax Per } \\
\text { Year Per }\end{array}$ \\
\hline & $\begin{array}{l}(\mathrm{L})=\text { Legislated } \\
(\mathrm{F})=\text { Forecast } 1\end{array}$ & $\begin{array}{l}\text { at Inception }^{\mathrm{a}} \\
100=\text { par }\end{array}$ & \multicolumn{2}{|c|}{$\begin{array}{l}1 \& 2 \\
100=\text { par }\end{array}$} & \multicolumn{2}{|c|}{$100=$ par } & \multicolumn{2}{|c|}{$100=$ par } & $\begin{array}{l}\text { White- } \\
\text { Capita }^{d}\end{array}$ \\
\hline \multicolumn{10}{|l|}{$\# 1$} \\
\hline $\begin{array}{l}\text { May 10, } 1775 \\
(\$ 3,000,000) \\
\# 2\end{array}$ & $\begin{array}{l}30 \text { Nov. } 1779- \\
30 \text { Nov. } 1782 \text { (L) }\end{array}$ & 69.73 & \multicolumn{6}{|c|}{ [69.73] [69.73] } & $\begin{array}{c}\$ 0.33 \\
0.35-0.31\end{array}$ \\
\hline $\begin{array}{l}\text { Nov. 29, } 1775 \\
\quad(\$ 3,000,000) \\
\# 3\end{array}$ & $\begin{array}{l}30 \text { Nov. } 1783- \\
30 \text { Nov. } 1786 \text { (L) }\end{array}$ & 56.68 & \multicolumn{6}{|c|}{$[64.37][64.37]$} & $\begin{array}{c}0.28 \\
0.30-0.27\end{array}$ \\
\hline $\begin{array}{l}\text { Feb. } 17,1776 \\
\quad(\$ 3,937,220) \\
\# 4\end{array}$ & $\begin{array}{l}30 \text { Nov. } 1787- \\
30 \text { Nov. } 1790 \text { (F) }\end{array}$ & 45.18 & \multicolumn{6}{|c|}{$57.21 \quad 57.16$} & $\begin{array}{c}0.33 \\
0.35-0.32\end{array}$ \\
\hline $\begin{array}{l}\text { May 9, } 1776 \\
(\$ 5,000,000) \\
\# 5\end{array}$ & $\begin{array}{l}30 \text { Nov. } 1791- \\
30 \text { Nov. } 1794 \text { (F) }\end{array}$ & 36.03 & \multicolumn{6}{|c|}{$50.48 \quad 50.38$} & $\begin{array}{c}0.36 \\
0.38-0.34\end{array}$ \\
\hline $\begin{array}{l}\text { July } 22,1776 \\
(\$ 5,000,000) \\
\# 6\end{array}$ & $\begin{array}{l}30 \text { Nov. } 1795- \\
30 \text { Nov. } 1798 \text { (F) }\end{array}$ & 28.70 & \multicolumn{6}{|c|}{$45.65 \quad 45.35$} & $\begin{array}{c}0.32 \\
0.33-0.31\end{array}$ \\
\hline $\begin{array}{l}\text { Nov. } 2,1776 \\
(\$ 5,000,000) \\
\# 7\end{array}$ & $\begin{array}{l}\text { Nov. 30, 1799- } \\
\text { Nov. 30, } 1802 \text { (F) }\end{array}$ & 22.94 & \multicolumn{6}{|c|}{$41.70 \quad 41.46$} & $\begin{array}{c}0.28 \\
0.30-0.27\end{array}$ \\
\hline $\begin{array}{l}\text { Feb. } 26,1777 \\
\quad(\$ 5,000,000)\end{array}$ & $\begin{array}{l}\text { Nov. 30, 1803- } \\
\text { Nov. 30, } 1806 \text { (F) }\end{array}$ & 18.45 & \multicolumn{6}{|l|}{38.52} & $\begin{array}{c}0.31 \\
0.38-0.24\end{array}$ \\
\hline \multicolumn{10}{|c|}{$\begin{array}{l}\text { Legal Tender Laws Enacted in } 1777 \text { Made All Emissions Fungible and so All Expected Present Values Cumulative } \\
\text { \#8 }\end{array}$} \\
\hline $\begin{array}{l}\text { May 20, } 1777 \\
(\$ 16,500,000) \\
\# 9\end{array}$ & $\begin{array}{l}\text { Nov. 30, 1807- } \\
\text { Nov. } 30,1810(F)\end{array}$ & \multicolumn{3}{|l|}{$14.70^{\mathrm{j}}$} & 13.41 & 9.61 & 30.40 & 30.02 & $\begin{array}{c}0.36 \\
0.76-0.24\end{array}$ \\
\hline $\begin{array}{l}\text { Apr. 11, } 1778 \\
(\$ 25,000,000) \\
\# 10\end{array}$ & $\begin{array}{l}\text { Nov. 30, 1811- } \\
\text { Nov. 30, } 1814 \text { (F) }\end{array}$ & \multicolumn{3}{|l|}{$12.18^{\mathrm{j}}$} & 14.17 & 10.15 & 25.11 & 23.52 & $\begin{array}{c}0.43 \\
1.03-0.24\end{array}$ \\
\hline $\begin{array}{l}\text { Sept. 26, } 1778 \\
\left(\$ 75,001,080^{\mathrm{e}}\right) \\
\# 11\end{array}$ & $\begin{array}{l}\text { Nov. 30, 1815- } \\
\text { Nov. 30, } 1818 \text { (F) }\end{array}$ & \multicolumn{3}{|l|}{$9.84^{\mathrm{j}}$} & 14.53 & 10.41 & 21.09 & 18.54 & $\begin{array}{c}0.49^{\mathrm{e}} \\
1.09-0.24\end{array}$ \\
\hline $\begin{array}{c}\text { Jan. } 14,1779^{f} \\
(\$ 199,989,995)\end{array}$ & $\begin{array}{l}\text { Nov. 30, 1779- } \\
\text { Jan. 1, } 1797 \quad \text { (L) }\end{array}$ & 62.38 & \multicolumn{6}{|c|}{$[62.38][62.38] 14.80^{\mathrm{g}}$} & $\begin{array}{c}3.66^{f} \\
6.95-2.59\end{array}$ \\
\hline $\begin{array}{l}\text { All Emissions } \\
(\$ 199,989,995)\end{array}$ & $\begin{array}{l}\text { April 1780- } \\
\text { April } 1781 \quad \text { (L) }\end{array}$ & $2.50^{\mathrm{h}}$ & {$[2.50]$} & {$[2.50]$} & $15.70^{\mathrm{g}}$ & $11.27^{\mathrm{g}}$ & & & $\begin{array}{l}86.72 \\
2.17^{\mathrm{i}}\end{array}$ \\
\hline \multicolumn{9}{|c|}{$\begin{array}{l}\text { Average Tax per Year per White-Capita in the } 13 \text { Colonies for All Taxes, 1770-1774: } \\
\text { Average Tax per Year per White-Capita for all U.S. Federal Government Taxes, 1792-1795: }\end{array}$} & $\begin{array}{l}0.41 \\
1.39\end{array}$ \\
\hline
\end{tabular}


Sources: Table 3.1; Carter, et al. (2006, v. 1, p. 36; v. 5, pp. 82, 652); Grubb (2008, 2012a); JCC (v. 2, pp. 221-3; v. 3, pp. 457-9; v. 13, pp. 20-1; v. 16, pp. 262-7; v. 17, pp. 567-8); Rabushka (2008, pp. 796, 825, 862-3). Notes: See Table 3.1 and the text.

${ }^{a}$ Continuously discounted at 6 percent off the face value on the bill from the redemption interval dates to the date printed on the bill expressed as the value of \$100 in Continental paper money. See fn. 16.

$\mathrm{b}$ This is the expected average par present values for the cumulative emissions outstanding to that date weighted by their dollar size. In other words, if one had a random draw of Continental dollars currently outstanding at this date, then this is what their average expected par present value would be. After emission \#7 legal tender laws make all expected values per specific emission average cumulative values for all currently outstanding emissions.

${ }^{\mathrm{C}}$ See text and Grubb (2012b) for details about how legal tender laws work. Perfect foresight expectations means that the public knew exactly how many Continental dollars would eventually be emitted. No foresight expectations means that the public did not take future emissions of Continental dollars into account when calculating the expected present value of a Continental dollar for the emissions issued so far and currently outstanding.

d This is the tax needed to redeem the promised or forecasted amount of Continental dollars at face value. It applies to legislated and Forecast 1 values only. Forecast 2 by construction is set at $\$ 0.33$. The range across the redemption interval for each emission is underneath the average number for that interval. Population is extrapolated linearly between decadal benchmarks and is for the white population only (Carter, et al. 2006, v. 1, p. 36; v. 5, p. 652). Only the tax needed to redeem Continental dollars at face value is reported. Taxes are expressed in Spanish silver dollars. Taxes expressed in pounds sterling are converted to Spanish silver dollars following McCusker (1978, p. 10). Legal tender laws merge emission redemptions after emission \#7. Thus, for emissions after emission \#7, the average tax covers redemption across all prior emissions and redemption years. The high number in the tax range for each emission after emission \#7 represents the per year per white-capita tax for the fourth to last year of redemption.

e Only the \$30,000,300 portion of emission \#10 authorized before 14 January 1779 is used to estimate the average tax per year per white-capita. After 14 January 1779 all emissions, including new authorizations of emission \#10, were merged into one redemption window.

f Applies to all past and future net new emissions $(\$ 199,989,995)$ regardless of the date on the bill.

$\mathrm{g}$ These are counterfactual expected present values using Forecasts 1 and 2 under the assumption that the new legislated redemption dates in 1779 and 1780 were not operative.

${ }^{\mathrm{h}}$ Enacted 18 March 1780 and covered all past emissions. How to calculate the expected present value at inception is unclear. The resolution's 40 to 1 conversion rate, paper Continental dollars to Spanish silver dollars, is used. See $J C C$ (v. 16, pp. 262-7).

${ }^{\mathrm{i}}$ Evaluated at 40 Continental dollars equals $\$ 1$ in specie as established in the 18 March 1780 resolution.

$\mathrm{j}$ These are counterfactual expected present values at inception for these individual emissions using Forecast 1 under the assumption that legal tender laws were not adopted.

frequent addition of new emissions that start at successively lower present values pulls down the average present value of all Continental dollars currently outstanding over the years of active emissions. This occurred because the frequency and size of new emissions, which add Continental dollars that start at relatively lower present values, outweigh the rising present value of the Continental dollars from prior emissions. Suppose at a given date one took a random draw of Continental dollars that were currently outstanding. The expected present value of that draw would be the average of the expected present values of the individual emissions at the date they 


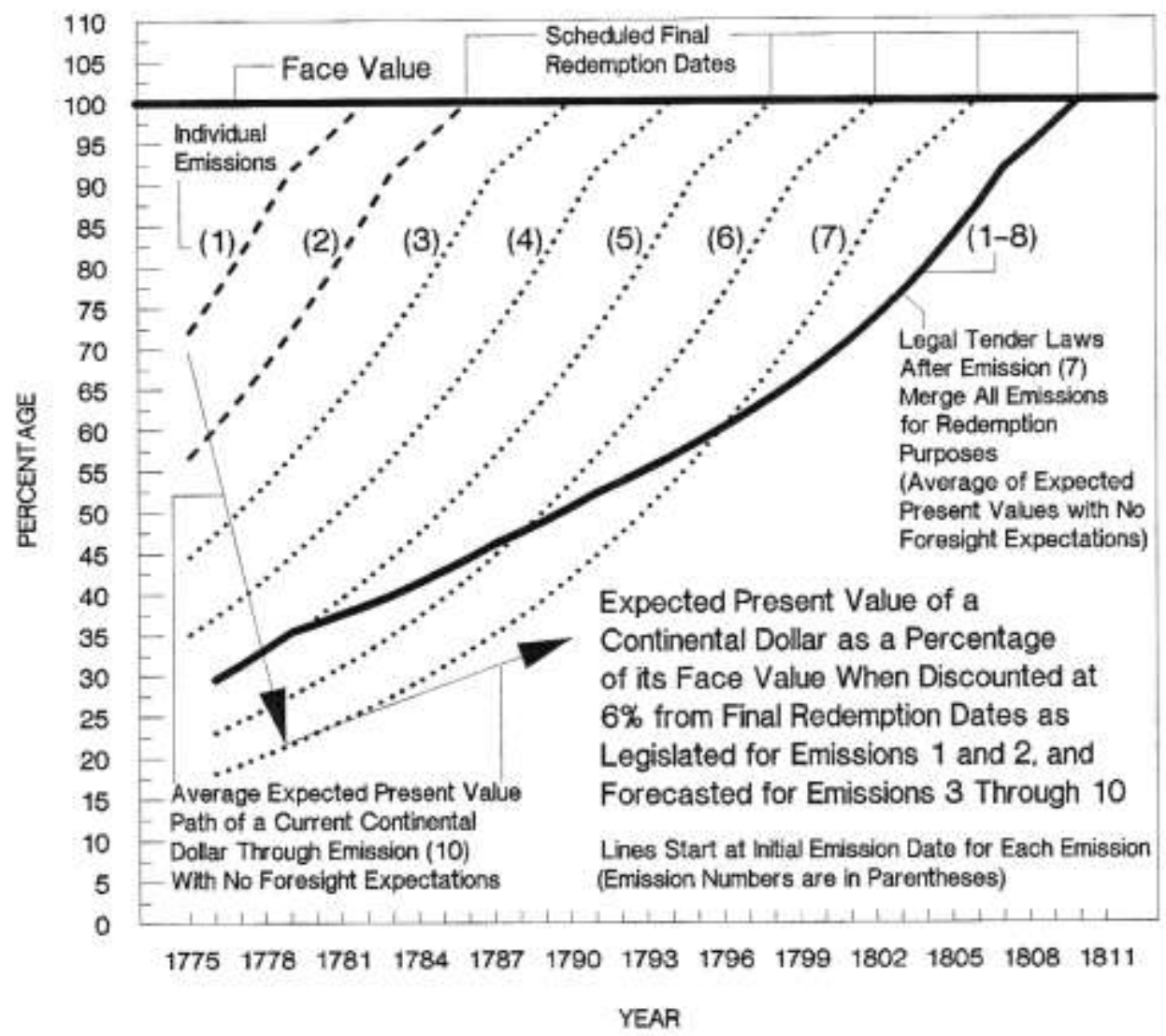

\section{Figure 3.4 Ideal Expected Present Value of a Current Continental Dollar: Face Value Discounted From Final Redemption at 6 Percent for Various Emissions and Cumulative Totals Using Forecast 1}

Sources: Derived from the sources in Tables 3.1 and 3.4.

Notes: See Table 3.4 and the text for discussion. Emission numbers are in parentheses.

were drawn. That average would, in turn, depend on the chance of randomly drawing bills from various outstanding emissions which, in turn, would depend on the relative size of each emission.

Column four of Table 3.4 shows these average expected present values at inception for each new emission through emission \#7, weighted by the nominal dollar size of all emissions currently outstanding. It uses the legislated redemption dates for emissions \#1 and \#2, and Forecasts 1 and 2 for emissions \#3 through \#7. This average of the expected present values at an emission's inception, column four, is above that for that emission's bills, column three, because 
bills from earlier emissions with higher present values are being averaged in with this emission.

Figure 3.5 illustrates the complete time-path for the ideal average expected present values presented in column four of Table 3.4 for emissions \#1 through \#7 (1775 to 1777). Forecasts 1 and 2 are so close to each other that they appear as a single dotted line prior to 1777. Comparing Figures 3.4 and 3.5 illustrates how the average expected present value is pulled down over time. The frequency and size of new emissions with their lower expected present values at inception outweigh the rise in the expected present value of earlier emissions. Given that the public's estimates of a Continental dollar's current value at any point in time would likely be made on a blind or random chance acquisition of Continental dollars among various outstanding emissions, i.e. not knowing in advance which emission a given dollar presented to them would be from, the times-paths in Figure 3.5 and column four in Table 3.4 represent the overall ideal present value at any point in time of a Continental dollar through early 1777 . This value shows that, even under ideal conditions with no uncertainty or depreciation per se, the average expected present value of a Continental dollar fell from 70 percent of its face value in May 1775 to 38 percent of its face value by March 1777. This was not depreciation, but simply the effect of timediscounting, i.e. the result of taking the value of time into account.

While the public could operate on the basis of forecasting an overall average expected present value of a Continental dollar as shown in Figure 3.5 through early 1777, it still faced the problem that Continental dollars known to be from different emissions should trade at different expected present values, see Figure 3.4. Once the emission date of a Continental dollar received in trade was revealed, the expected present value of that dollar could depart substantially from the overall average expected present value at that date as shown in Figure 3.5. Congress had created these differences in their initial structural design of the Continental dollar. Such 


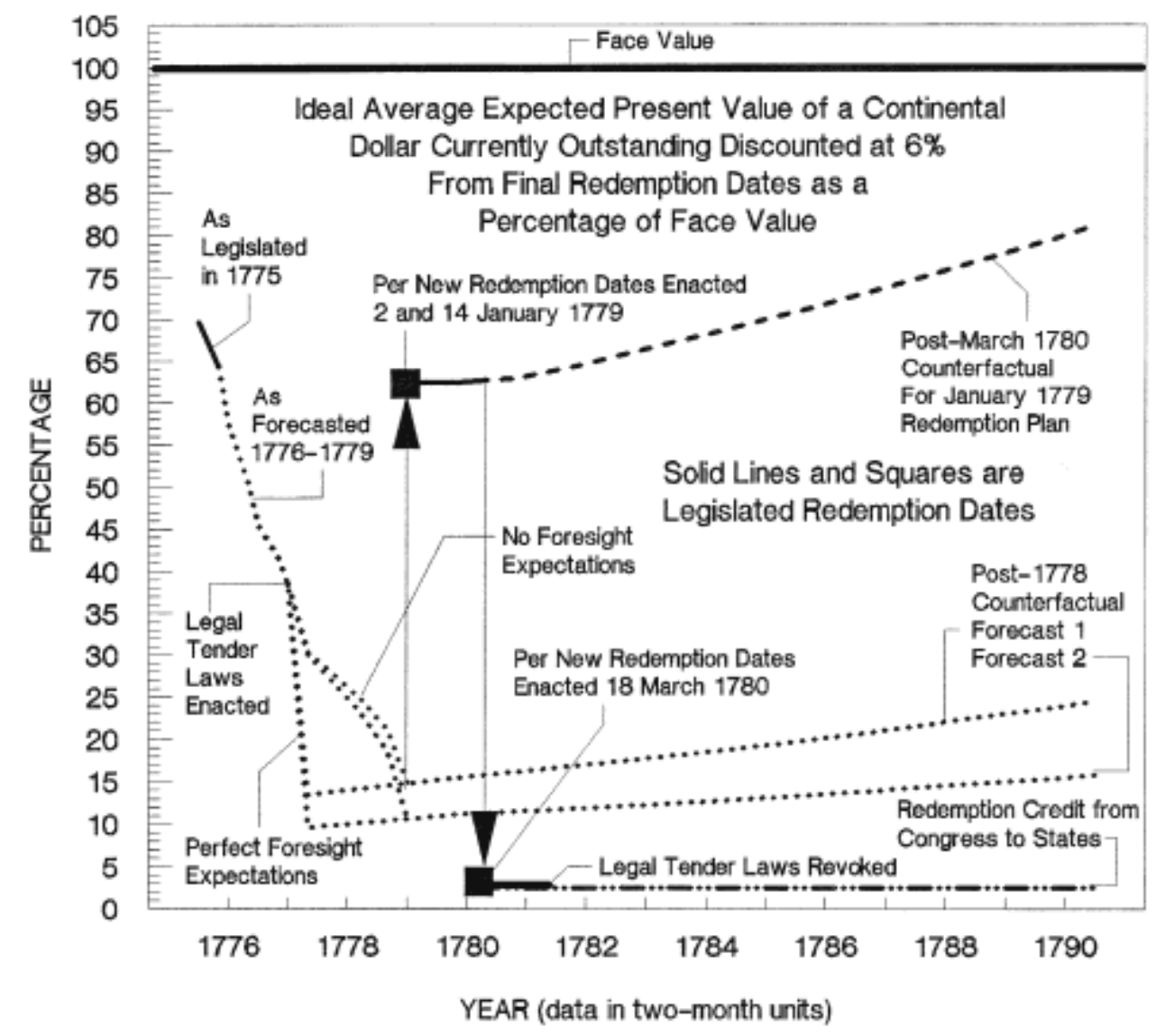

\section{Figure 3.5 Ideal Average Expected Present Value of a Continental Dollar Currently Outstanding Discounted at 6 Percent from Final Redemption Dates as Legislated and Forecasted Expressed as a Percentage of Face Value}

Sources: Derived from Tables 3.1 and 3.4.

Notes: See Table 3.4 and the text for discussion. Ideal means with certainty of redemption as promised.

differences across emissions made for a cumbersome medium of exchange.

Before the Revolution, individual colonies had solved this problem by making their respective bills of credit a legal tender at face value within their respective jurisdictions. Legal tender laws made bills from different emissions that were currently outstanding fungible, in effect merging emission-specific redemption windows for currently outstanding bills into one big window. Under legal tender laws, which bills were redeemed in which emission redemption windows no longer mattered as long as cumulative redemptions over the entire redemption 
window for all emissions matched cumulative emissions.

Legal tender laws allowed the public to respond to what the expected present value of a Continental dollar was at each point in time independent of emission dates for all bills currently outstanding. In other words, assessing the expected present value of a Continental dollar no longer depended on a blind random draw of bills currently outstanding. That assessment remained valid even if a non-random composition of emissions in a sample of Continental dollars was known ahead of time. Legal tender laws rendered the expected present value timepaths for each emission in Figure 3.4 irrelevant. Only the overall expected present value timepath in Figure 3.5 mattered for knowing the current value of any Continental dollar.

Because legal tender laws made emission-specific redemption windows irrelevant, it freed Congress from linking each emission to a unique authorization by breaking the relationship between a specific emission and its accompanying emission-specific redemption instructions (or its forecasted instructions). Congress could now authorize additional amounts at several subsequent dates under the umbrella of the same emission. Table 3.1 shows this behavior. Before legal tender laws, i.e. before emission \#8, each emission had one authorized amount. After legal tender laws, i.e. after emission \#7, each emission now had multiple authorization dates when additional sums were added to that emission. Under legal tender laws, emissions could and did become much larger in size.

As expectations of a brief conflict waned, the need for more emissions became clear, and the public's use of Continental dollars as a medium of exchange became more likely, Congress moved to solve the structural problem they had created whereby different emissions should trade contemporaneously at different expected present values. They did this by asking the states to make the Continental dollar a legal tender within their respective jurisdictions. On the same day 
that emission \#4 was authorized, 22 May 1776, a congressional committee consisting of James Duane, George Wythe, John Adams, Roger Sherman, Joseph Hewes, Thomas Johnson, and William Whipple recommended that Congress ask the states to make the Continental dollar a legal tender. The committee, now including Thomas Jefferson, made the same recommendation on 2 September 1776. Finally, on 14 January 1777, after emission \#6 had been authorized, Congress acted on the committee's recommendation and asked the states to make the Continental dollar a legal tender at face value within their respective jurisdictions. ${ }^{45}$ The states quickly accommodated this request. For example, Pennsylvania made the Continental dollar a legal tender on 6 February 1777, Delaware on 22 February 1777, and Virginia on 5 May 1777. By emission \#8, authorized on 22 May 1777, Continental dollars were legal tender at face value. ${ }^{46}$ With emission \#8, after May 1777, legal tender laws made Continental dollars from different emissions have the same expected present value in contemporaneous trades. Before May 1777, however, Continental dollars from emissions \#1 through \#7 should have traded contemporaneously at different values. Little direct evidence of differential treatment across emissions pre-1777 has been previously noted, in part because no one has looked for it, which in turn may be due to data difficulties. Market participants typically recorded monetary transactions in units of account and not media of exchange. ${ }^{47}$ For example, in Figure 3.6, out of 3,127 commercial advertisements placed in the Pennsylvania Gazette between March 1775 and April 1780 that listed a monetary statement, only 3 percent referred to a particular money or medium

45 JCC (v. 4, pp. 293-4, 380-3; v. 5, pp. 608, 724-8; v. 7, pp. 35-6).

${ }^{46}$ See Cushing (1981, v. 2, part 1, pp. 599-602); Hening (1969, v. 9, pp. 297-8); JCC (v. 4, pp. 294, 381-3; v. 5, pp. 608, 724-8; v. 7, pp. 35-7); Smith (1980, v. 6, p. 261); Statutes at large of Pennsylvania (1903, v. 9, pp. 34-40). When a state made the Continental dollar a legal tender within its jurisdiction, this meant that state-imposed fees and taxes could now be paid in Continental dollars at a legally set equivalence to that state's paper money. This may have been an effort to add some current positive liquidity premium to the Continental dollar. Given that states did not remit Continental dollars to the Continental Treasury until November 1779, state taxes paid in Continental dollars under the auspices of their being a legal tender did not materially affect the redemption of Continental dollars ahead of that legislatively scheduled and prudently forecast, see Grubb (2012a, pp. 156-60, 170).

${ }^{47}$ Bezanson (1951, pp. 3-4, 10-11). 


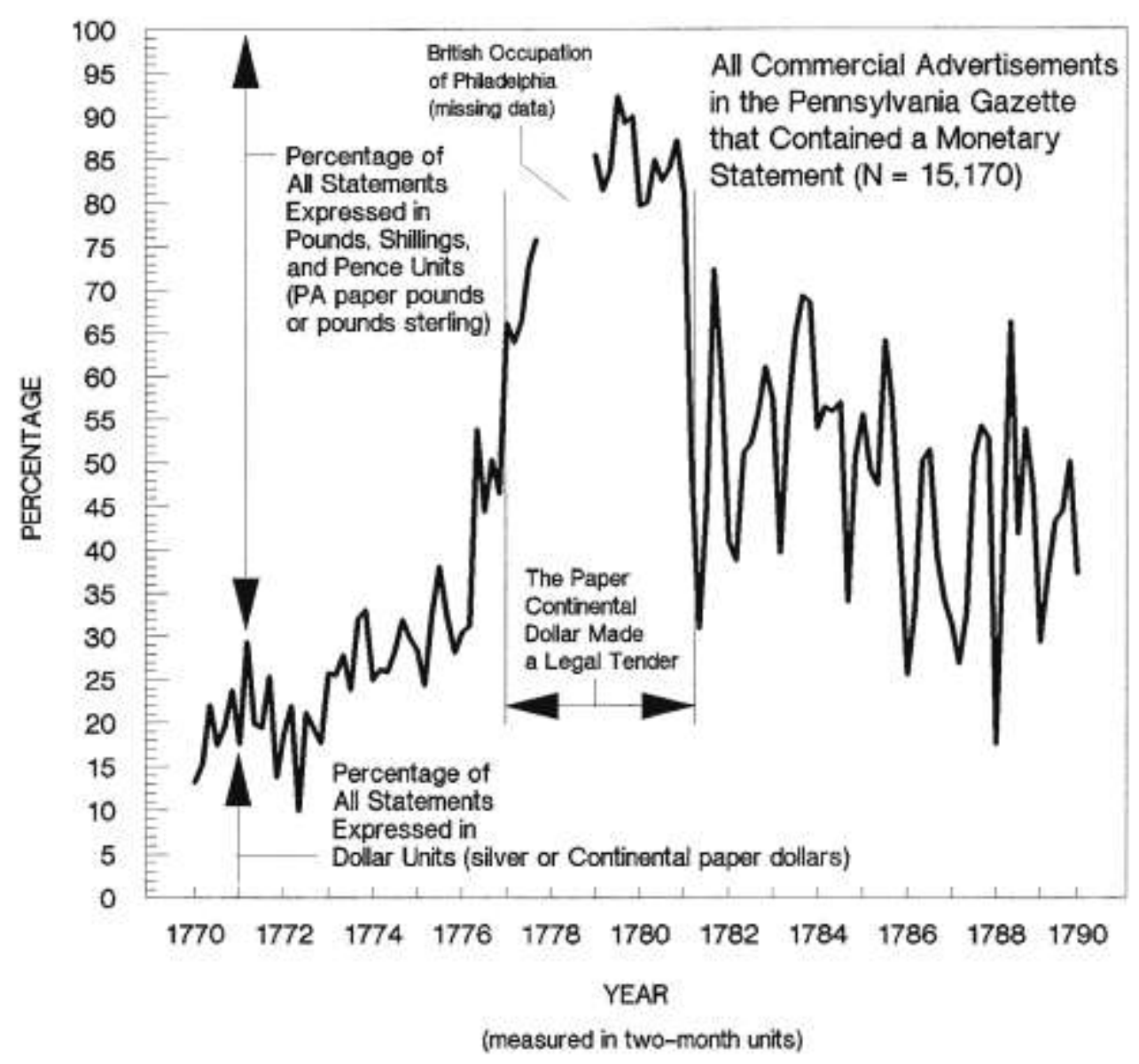

Figure 3.6 Prevalent Unit of Account in Marketplace Transactions in Philadelphia, 1770 to 1790

Source: Pennsylvania Gazette.

Notes: All commercial advertisements placed in the Pennsylvania Gazette were examined. Data are organized in two-month units. Line breaks indicate missing data (newspapers). Dollar units include Spanish silver dollars and Continental paper dollars. Pounds, shillings, and pence units include Pennsylvania paper pounds and pounds sterling monies.

of exchange as opposed to just listing the unit of account used, obscuring value distinctions between particular monies. That said, on 20 February 1777, Congress' Committee on Way and Means for supplying the Treasury made a recommendation that entailed distinguishing between the first two emissions and subsequent emissions. Such a distinction only made sense if 
Continental dollars from different emissions were perceived to have different present values. ${ }^{48}$

After 1777, congressional payments for war supplies absorbed more Continental dollars than soldiers' pay. ${ }^{49}$ While soldiers' pay had been fixed in nominal terms by Congress on 29 July 1775, when Congress spent Continental dollars in the marketplace for supplies and services, prices could be raised by suppliers and service providers to reflect the expected present value of the Continental dollars offered in payment. Suppliers and service providers were more likely to re-spend the money paid them because they had subcontractors and employees to pay. Figure 3.6 shows that market participants in Philadelphia did not start denominating transactions in dollar units, above that used prior to the first emission of Continental dollars, until sometime after mid1776. By mid-1777, the public was pricing goods primarily in Continental dollars.

That Congress waited until 1777 to ask the states to make the Continental dollar a legal tender is consistent with this transition in usage. As war supplies came to dominate congressional spending, Continental dollars had to become a less cumbersome transacting medium of exchange. This was difficult to achieve if Continental dollars with different emission dates had different contemporaneous expected present values. Legal tender laws eliminated this problem. The public could now think in terms of one overall expected present value for any Continental dollar outstanding independent of the emission date on the bill.

When Congress altered the redemption rules on 2 January 1779, see Table 3.1, they explicitly made the expected present value of all Continental dollars identical regardless of emission date. They did this by establishing one overall redemption window for all Continental dollars ever emitted. Theoretically, this action had the same effect as states making the Continental dollar a legal tender within their respective jurisdictions. That Congress explicitly

\footnotetext{
${ }^{48}$ JCC (v. 7, pp. 136-8). Congress did not adopt this part of the committee's recommendation. The committee's report was written by Roger Sherman. See also Smith (1982, v. 9, pp. 491-2, 632).

${ }^{49}$ See Grubb (2011, pp. 274-6).
} 
took this action for the first time in 1779 may have added to the certainty that all Continental dollars now had the same expected present value regardless of emission date. A few market participants took notice. Edward Bonsall and Abraham Shoemaker advertised in the 27 January 1779 Pennsylvania Gazette that they would sell a tract of land "For Continental Currency of any date [italics in the original]." The implication of this previously unused phraseology is that prior to 2 January 1779 Continental dollars from different emissions may occasionally have been treated differently when settling accounts. Not all citizens may have understood that legal tender laws had already implicitly accomplished what the 2 January 1779 congressional resolution explicitly accomplished. ${ }^{50}$

Legal tender laws altered the public's present value forecasts. A simple average of the expected present values of outstanding emissions weighted by emission size, used before legal tender laws were enacted, i.e. Table 3.4 column four, was no longer valid. Prior to legal tender laws, adding a new emission lowered the average expected present value of a random draw of Continental dollars, but not by lowering the expected present value of any prior emission. It did so merely by adding in the weight of the new emission's lower expected present value. Under a legal tender law, this was changed. By continuously merging and remerging all prior emissions’ redemption windows with each new emission's redemption window into one big constantly growing redemption window, legal tender laws caused each new emission to lower the expected present value of all prior emissions. In other words, under legal tender laws, each emission exerted a negative externality on all other emissions' expected present values. Because future emissions now impacted prior emissions' expected present values, under legal tender laws the public had to forecast future emissions in order to calculate a current expected present value of a

\footnotetext{
50 See also the Pennsylvania Gazette (10 and 17 February, 7 and 14 April 1779).
} 
Continental dollar.

Column five of Table 3.4 presents two alternative expectations of future emissions used to recalculate the expected present value at inception for emissions \#8 through \#10 using Forecasts 1 and 2 under legal tender laws. The first alternative assumes the public had perfect foresight regarding the number and size of future emissions of Continental dollars. The second alternative assumes the public was myopic and had no foresight regarding future emissions. In other words, it assumes the public thought each current emission would be the last emission. The perfect foresight alternative is likely the most reasonable. As early as mid-1777 and certainly by 1779 there was strong sentiment among Americans that the war had been won and would soon be over. The public could gauge the yearly cost of the war and, and with some idea of when the war would end, could then gauge future Continental dollar emissions. Congress had started debating an end to emissions, and in 1779 set a \$200 million limit for total cumulative emissions. ${ }^{51}$ That the last emission occurred when the first redemptions were to be received by the Continental Treasury was likely no coincidence, and so something expected by the public.

Forecasting war costs that required Continental dollars after mid-1777, based on average monthly war costs from 1775 into 1777, turned out to be fairly accurate. For example, the present value of congressional spending of Continental dollars from emissions \#1 through \#7 was approximately \$11 million, or \$529,101 per month on average from September 1775 through April 1777. This is almost exactly what Thomas Jefferson estimated in July of 1775, namely that each six months of war would cost $\$ 3$ million. ${ }^{52}$ Using this number to forecast the present value of Continental dollars needed per month to continue the war from May 1777 through March 1780 yields approximately \$18.5 million. The total present value of Continental

\footnotetext{
51 See JCC (v. 8, p. 453; v. 14, pp. 719, 728, 730, 732, 783, 901, 1013-4; v. 15, pp. 1019, 1053, 1171, 1324); Smith (1985, v. 11, pp. 487-8; 1985, v. 12, p. 500; 1998, v. 25, p. 641).

52 Smith (1976, v. 1, pp. 689-91).
} 
dollars emitted after emission \#7 equaled between \$17.6 and \$24.6 million using Forecasts 1 and 2 with perfect foresight expectations, respectively. ${ }^{53}$ As such, the projected $\$ 18.5$ million in present value needed to finish the war based on past behavior is close to the perfect foresight expectation of the number and size of future emissions needed after emission \#7, in present value terms using Forecasts 1 and 2, to finish the war. Therefore, the perfect foresight expectation approximates fairly closely the forecast of future emissions based on projecting past behavior.

The difference between the perfect foresight and the no foresight forecast, see Table 3.4 column five and Figure 3.5, illustrates the size of the negative externality caused by legal tender laws on the expected present value of currently outstanding Continental dollars. Under perfect foresight, the adoption of legal tender laws after emission \#7 caused the expected present value to fall from 38.5 percent of face value at the inception of emission \#7 to between 9.5 and 13.5 percent of face value at the inception of emission \#8. This was the lowest forecasted expected present value. From that point forecasted expected present values would rise continuously between the inception of emission \#8 and the year when the last Continental dollar ever emitted would be redeemed. This result occurs because the public knows how many future Continental dollar emissions will occur and what the size of those emissions will be. Thus, they know when the last redemption year will be, and because the inception of emission \#8 is the farthest away in time from the last redemption year, its expected present value is the lowest.

By comparison, if the public is myopic and has a no foresight forecast then, with the adoption of legal tender laws after emission \#7, the expected present value falls from 38.5 percent of face value at the inception of emission \#7 to only 30 percent of face value at the inception of emission \#8. This is 18.5 percentage points less than the fall under the perfect

\footnotetext{
53 The example is derived from Tables 3.1 and 3.4. For the rest, see $J C C$ (v. 14, p. 1013; v. 15, pp. 1019, 1053, 1171, 1324); Smith (1984, v. 11, pp. 487-90).
} 
foresight assumption. From that point, the forecasted expected present value falls with each successive emission under the no foresight calculation, while it continues to rise under the perfect foresight calculation, until the two rejoin at the inception of the last emission in January of 1779 (emission \#11) at between 10.6 and 14.8 percent of face value, see Table 3.4 column five and Figure 3.5. Thereafter the two foresight expectations yield identical expected present value forecasts for both Forecasts 1 and 2. This last result is because, after the last emission, assuming that the public pretends that no more emissions will occur, and assuming that the public perfectly foresees that no more emissions will occur, are identical assumptions.

The adoption of legal tender laws after mid-1777, assuming perfect foresight expectations, produced a substantial collapse in the expected present value of Continental dollars currently outstanding during the critical year of 1777. In effect, by requesting that the states adopt legal tender laws, Congress was trading off a substantial reduction in the expected present value of Continental dollars already outstanding for making Continental dollars a less cumbersome medium of exchange. Even this improved medium-of-exchange function may not have been realized due to the extreme length of the redemption window needed to create it.

Legal tender laws made all Continental dollars regardless of emission number, or date on the bill, have the same expected present value, thus making them a less cumbersome medium of exchange. It accomplished this by merging the redemption windows for all emissions into one large redemption window. This method, however, increased the variance in the realized value of Continental dollars at any point in time. At the inception of emission \#8, the redemption window for Forecasts 1 and 2 under perfect foresight was 43 and 72.5 years, respectively. Under the no foresight assumption, it was 31 and 34.5 years, respectively. These are much longer redemption windows than the typical four-year window forecasted for each separate emission \#3 through \#7 
before legal tender laws were enacted. This long redemption window increased the range of realized values around the now common average value.

With emission \#8 and the adoption of legal tender laws, under perfect foresight using Forecasts 1 and 2, a given Continental dollar could now end up being redeemed at face value as early as 1779 or as late as 1822 or 1852, respectively. If a citizen knew in advance which Continental dollar would be redeemed in 1779 versus which in 1822 or 1852, they would be willing to pay more than the expected average for the one redeemed in 1779, and less than the expected average for the one redeemed in 1822 or 1852. For example, under perfect foresight using Forecasts 1 and 2, at the inception of emission \#8, while the expected present value of any Continental dollar was 13.4 and 9.6 percent of face value, respectively, the range around these averages was 86.1 to 6.5 percent of face value for Forecast 1, and 86.1 to 1.11 percent of face value for Forecast 2. Under no foresight using Forecasts 1 and 2, at the inception of emission \#8, while the expected present value of any Continental dollar was 30.4 and 30.0 percent of face value, respectively, the range around these averages was 86.1 to 13.4 percent of face value for Forecast 1 and 86.1 to 10.9 percent of face value for Forecast 2, see Table 3.4.

While most citizens did not know in advance which Continental dollar would be redeemed in which year within the redemption window, and so would use the common expected present value when transacting in Continental dollars, the shear range of possible realized values around that common average imparted additional risk to using Continental dollars as a medium of exchange. Congress had created no mechanism to determine which specific Continental dollar would be redeemed in which year. If everyone rushed to the Continental Treasury in 1779 with their Continental dollars, how the Treasury would decide which to accept to fill that year's quota and which to turn away was undetermined. Insider knowledge and political favors intruding into 
the actual redeeming process must have been a concern and something that would affect the value-stability of the system. The variance in realized values produced by a four-year redemption window may have been a minor inconvenience, but that produced by a 31 or a 73 year redemption window had to be a major concern, carrying a substantial risk cost, when trading in Continental dollars after emission \#7.

An additional rationale for Congress' requesting that the states adopt legal tender laws in 1777 is shown in Figure 3.4. This rationale, however, is largely based on Congress' assuming the public had no foresight expectations regarding the number and size of future emissions. Table 3.4 column three and Figure 3.4 show that the expected present value of emissions \#6 and \#7 at their inceptions were low, 23 and 18 percent of face value, respectively. If nothing was done, the expected present value of the next emissions (\#8) at its inception would be even lower. The purchasing power Congress expected from a new emission, even with zero depreciation, was rapidly vanishing due to forecasted time-discounting.

If the public operated under a no foresight expectation regarding future emissions, then adopting legal tender laws would twist and flatten the expected present value time-path of the merged emissions \#1 through \#8 such that the expected present value of new emission \#8 at its inception would now be well above what it was for emissions \#5 through \#7 at their respective inceptions, see Table 3.4 columns three and five, and Figure 3.4. This action made the expected present value of emission \#8 at inception 30 percent of face value rather than 15 percent of face value if no legal tender laws were adopted, or almost twice as high in terms of percentage points. Thus, the purchasing power Congress would enjoy with its new emission \#8 was enhanced. Similarly, the differential produced in Congress' purchasing power for emissions \#9 and \#10 by adopting legal tender laws was about 10 percentage points above what it would have been if no 
legal tender laws had been adopted. However, if the public had perfect foresight expectations regarding the number and size of future emissions, then far less was gained by Congress in the purchasing power of its new emissions, at best about a 4 percentage point higher expected present value by emission \#10 under legal tender laws compared with no legal tender laws.

If this alteration in the time-path of redemption, solid line (1-8) in Figure 3.4, was Congress' intention, in addition to making the Continental dollar a less cumbersome medium of exchange, it came at an additional cost. The adoption of legal tender laws sacrificed the present value expected by holders of prior emissions in order to prop up the present value of the new emission Congress was now spending. This was a kind of breach of faith that damaged the credibility of Congress and the Continental dollar financing system. It amounted to a retrospective change in the present value of outstanding zero-interest bonds through unilaterally imposing a legal postponement in their likely day of redemption. This cost along with the sharp and large collapse in expected present value in 1777 caused by the adoption of legal tender laws under perfect foresight expectations put destructive pressure on the Continental dollar finance system. ${ }^{54}$ Legal tender laws imposed additional costs and garnered no more benefits that those mentioned here (Grubb 2012b). This raises questions about why Congress advocated the adoption of legal tender laws. Whether it was out of ignorance, stupidity, or Machiavellian politics, will be taken up in future papers.

\section{IDEAL REDEMPTION PERFORMANCE AFTER EMISSION \#10}

On 2 January 1779, 12 days prior to authorizing what would be the last emission (\#11), Congress changed redemption requirements for all Continental dollars. The Board of Treasury and Congress finally responded to their administrative failure to explicitly establish redemption

\footnotetext{
54 See Smith (1980, v. 6, pp. 602, 606; 1981, v. 7, pp. 21, 24, 172, 462; v. 8, pp. 35, 374; 1982, v. 9, pp. 3-4, 326).
} 
windows for emission \#3 through \#10. This failure, and its ill effects, had been noted by the state Commissioners meeting in New Haven in their January 1778 letter to Congress (discussed above). The Board of Treasury's preamble to the 2 January 1779 resolution read,

Whereas, these United States, unprovided with revenues, and not heretofore in a condition to raise them, have, in the course of the present war, repeatedly been under the necessity of emitting bills of credit [Continental dollars], for the redemption of which the faith of these United States has been solemnly pledged, and the credit of which their honor and safety, as well as justice, is highly concerned to support and establish; and whereas, to that end, it is essentially necessary to ascertain the periods of their redemption, and seasonally establish funds which, in due time, without distressing the people, shall make adequate provision for the same: ${ }^{.5}$

All the structural procedures from 1775 were kept in place except the redemption installment amounts and the length of the contiguous-year redemption window. The specie redemption option for citizens at the Continental Treasury was not mentioned in the 2 January 1779 resolution. However, Congress indicated that it was still operative on 14 June $1779 .{ }^{56}$ All past and future emissions were now to be fungible in redemption, explicitly codifying nationally what had only been an implicit outcome of legal tender laws enacted piecemeal in 1777 by individual states. The resolution also indicated that net new emissions would end in 1779 . The states were now to redeem $\$ 15$ million in 1779 , by 30 November, and an equal amount each year through 1797, the amount needed to exhaust the remainder, see Table 3.1.

On 1 September 1779, Congress set a \$200 million limit for total net new emissions. ${ }^{57}$ Congress made sure it reached that limit by 29 November 1779, the day before the first redemptions were scheduled to be received by the Continental Treasury. Thus, by the end of 1779 the states were required to remit 10,277,222 Continental dollars each year from 1780 through 1797 to the Continental Treasury to be burned. Eighteen years times 10,277,222 plus

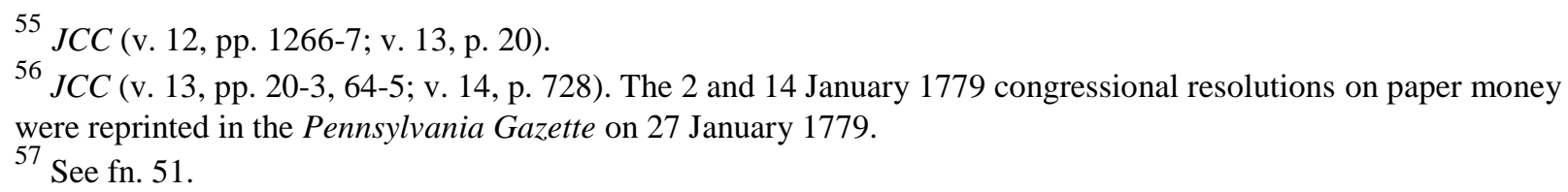


15,000,000 for 1779 equals 199,989,995 net new Continental dollars actually emitted, versus the $\$ 200$ million Congress thought it had emitted, see Table 3.1. This number is net of some undetermined amount of Continental dollars remitted by the states after 1779 that the resolution allowed to be re-spent, rather than destroyed, to pay off loan-office certificate principal and interest on loans issued before 1780. Total state remittances of Continental dollars after 1779, therefore, had to be somewhat higher than $\$ 10,277,222$ per year to achieve the permanent removal of these re-spent Continental dollars from circulation.

The current Board of Treasury that brought the 2 January 1779 resolution before Congress consisted of Oliver Ellsworth, Elbridge Gerry, Richard Huston, Richard Henry Lee, Gouverneur Morris, Edward Telfair, and John Witherspoon. Only Lee had been in Congress in 1775 for the debate and passage of the resolutions establishing the structural design and redemption windows for the first two emissions of Continental dollars. Only Ellsworth, Gerry, and Witherspoon from the Board of Treasury, however, were present in Congress for the 2 January 1779 vote on the resolution (members of the Board were all congressmen). The resolution passed nine states to two, with only William Whipple of New Hampshire and John Henry of Maryland opposed. Only six of the 23 congressmen voting on this resolution were present in Congress in 1775 for the debates and passage of the resolutions establishing the structural design and redemption windows for the first two emissions. These six included three members of the New York delegation, namely John Jay, James Duane, and William Floyd; Eliphalet Dyer of Connecticut; Samuel Adams of Massachusetts; and Francis Lightfoot Lee of Virginia. ${ }^{58}$

Of these six individuals, Duane's proposal in 1775 to shorten the redemption window for

58 See JCC (v. 11, p. 731; v. 12, pp. 1130, 1134; v. 13, p. 23); Smith (1976, v. 1, pp. xxvi-xxxii; 1977, v. 2, pp. xvixxii). Lee was not present for the debate and passage of emission \#1 resolutions, and Floyd may not have been present when that resolution passed. 
emission \#2 had been rejected by Congress, and Jay and Adams had sat on a committee that in early 1776 had its proposal to call in all Continental dollars and replace them with much largervalued interest-bearer bonds rejected by Congress. For these three individuals, educating the other congressmen in 1779 on the principles and rationale underlying Congress' 1775 structural design of the Continental dollar may not have been a priority or in their personal interest. It may have even been outside their understanding. Whipple, who was not in Congress in 1775, but was there in early 1776 and sat on the coin rating committee, may have absorbed enough about the 1775 structural design to understand that the changes to that design made by the 2 January 1779 resolution were problematic, thus explaining his vote against that resolution. ${ }^{59}$

Establishing the time path of the ideal expected present value of Continental dollars under the 2 January 1779 resolution comes with caveats. If these caveats are ignored, then that ideal at the inception of emission \#11 would become 62 percent of face value, which was 48 and 52 percentage points higher than that projected by Forecasts 1 and 2, respectively, see Table 3.4. Figure 3.5 shows this revaluation in the ideal expected present value, and then how thereafter it would slowly appreciated to face value by $1797 .^{60}$ If this resolution was credible, a radical revaluation of the Continental dollar would have been achieved.

The 2 January 1779 resolution's radical reevaluation of the ideal expected present value of the Continental dollar, compared with Forecasts 1 and 2, was caused by substantially shortening the redemption window from what prevailed in these forecasts. The resolution's redemption window ran for 18 years, from 1779 to 1797, with relatively more redeemed in the first year than in subsequent years. By contrast, the redemption windows for Forecasts 1 and 2, at the inception of emission \#11, ran for 43 and 73 years, respectively. These windows also had

\footnotetext{
59 See fns. 8, 10, and 31.

${ }^{60}$ See JCC (v. 14, p. 728).
} 
equal nominal amounts paid in each year. They were not frontloaded as the 2 January 1779 window was. Having more redeemed in the early years of a redemption window compared with the latter years raised the ideal expected present value over that of an evenly spaced redemption window. What Congress did with the 2 January 1779 resolution was consist with the advice sent to them by the state Commissioners meeting in New Haven in January 1778 (discussed above). These Commissioners recommended that Congress remedy the missing redemption instructions for emissions after \#2 by establishing a "short period" for the redemption. They thought that a "short period" would give the public "confidence in the money" and "Establish its currency". Apparently Congress, in early 1779, agreed with this view. ${ }^{61}$

While the 2 January 1779 resolution filled in the missing redemption instructions for the eight preceding emissions, thus giving the system more certainty than before, it also altered the redemption pattern set in the first two emissions passed by Congress in 1775. As such, the expectations built into Forecasts 1 and 2 were no longer valid. Given that these expectations were based on the likely fulfillment of ideal conditions, such as certainty of redemption at face value in specie as promised, the ideal expected present value calculated under the 2 January 1779 resolution may be outside the bounds of reality.

Emissions \#1 and \#2, and consequently Forecasts 1 and 2, were predicated on redemption taxes being within historically acceptable and fiscally feasible limits. This allowed for the calculation of an ideal expected present value. Table 3.4 shows that with emission \#11, under the 2 January 1779 redemption structure, per year per white-capita taxes would need to be multiple times above these historically acceptable and fiscally feasible levels. They were even multiple times above the tax levels achieved by the Federal Government from 1792 through 1795 after it

${ }^{61}$ Hammond (1889a, p. 293). 
had acquired direct taxing powers under the U.S. Constitution. These observations raise questions about the fiscal credibility of the 2 January 1779 redemption structure and thus about the presumed certainty of redemption as promised -an assumption needed to make an ideal present value calculation. While the Board of Treasury in its preamble to the resolution intended to "establish funds," i.e. taxes, "without distressing the people," it is hard to see the level of implied taxation as anything short of "distressing." As such, an ideal expected present value calculation may not be valid for the 2 January 1779 redemption structure. The issue of credible commitment will be taken up in more detail in a future paper.

Given this caveat, the ideal expected present value of a Continental dollar under Forecasts 1 and 2 are extended through emission \#11 in Table 3.4 and Figure 3.5. These are counterfactual ideal expected present value estimates under the assumption that the new redemption window legislated in 1779 was not operative. They, rather than the 2 January 1779 redemption structure, should be used as the most credible benchmark against which empirical measures of depreciation should be evaluated. Again, this is because the ideal must be based on certainty of redemption and thus the fiscal credibility of the redemption taxes required. The 2 January 1779 redemption structure was not so based, while Forecasts 1 and 2 were.

Finally, on 18 March 1780, Congress replaced the redemption structure legislated 2 January 1779 with a new redemption structure. States were now to redeem 15 million Continental dollars each month over the next 13 months. Thirteen months times \$15 million equaled \$195 million or 97.5 percent of the Continental dollars ever emitted. The remaining \$5 million were due in the future from Georgia, which having been invaded was temporarily exempt from sending remittances. The states were also allowed to substitute one Spanish silver dollar in lieu of 40 Continental dollars when filling their quotas. The 18 March 1780 resolution did not 
remove the option citizens had to redeem their Continental dollars directly at the Continental Treasury for their face value in specie, as stated in the 29 July and 26 December 1775 resolutions and in congressional discussions on 14 June $1779 .^{62}$

Only six of the 28 congressmen, 21 percent, voting on the 18 March 1780 resolution had voted on the 2 January 1779 resolution. While all six had voted for the 2 January 1779 resolution, two voted against the 18 March 1780 resolution, namely Thomas Burke of North Carolina and Cyrus Griffin of Virginia. Only one member of the Board of Treasury crafting the 2 January 1779 resolution, Oliver Ellsworth of Connecticut, was present and voted on the 18 March 1780 resolution, voting in favor. At best, only four of the 28 congressmen voting on the 18 March 1780 resolution, i.e. Roger Sherman of Connecticut, Robert R. Livingston and William Floyd of New York, and Thomas McKean of Delaware or 14 percent, were congressmen in 1775 and present for at least some of the debate and passage of the initial structural design of the Continental dollar embedded in the first two emissions. Of these, only McKean voted against the 18 March 1780 resolution. Finally, only Floyd, 3.6 percent, voted on both the 18 March 1780 and 2 January 1779 resolutions and was also present for part of the 1775 debate and passage of the initial structural design of the Continental dollar. ${ }^{63}$ By 1780, there was little direct institutional memory based on personal knowledge left in Congress regarding the rationale for the initial structural design of the Continental dollar. The original designers, explainers, and advocates were gone. No core group of congressmen involved with and voting on all monetary and finance matters existed continuously from 1775 through 1780 .

The 18 March 1780 resolution passed six states in favor to five states opposed, with one

\footnotetext{
62 Ferguson, et al. (1973, v. 1, p. 194); JCC (v. 14, p. 728; v. 16, pp. 262-7). This act was printed in the Pennsylvania Gazette on 29 March 1780.

63 See fn. 58; JCC (v. 13, p. 23; v. 16, p. 267); Smith (1976, v. 1, pp. xxvi-xxxii; 1977, v. 2, pp. xvi-xxii). Livingston and Floyd may not have been present when the 1775 resolutions on the structural design of the Continental were passed.
} 
state divided. As such, this resolution was a more controversial change in redemption structure than that passed on 2 January 1779. Interestingly, the vote split sharply on a North-South divide. Not only did all the states south of Pennsylvania, i.e. Delaware, Maryland, Virginia, North Carolina, and South Carolina, vote against the resolution, but every single delegate from these states voted against it (no vote from Georgia was recorded). By contrast, not only did every single state north of Delaware vote in favor of the resolution (New Hampshire was divided), but every single delegate from these states, with the exception of Nathaniel Peabody of New Hampshire and John Fell of New Jersey, voted in favor of it. ${ }^{64}$ Explaining this North-South split will be taken up in more detail in a future paper.

As with the 2 January 1779 resolution, the time path of the ideal expected present value of a Continental dollar under the 18 March 1780 resolution comes with caveats. If these caveats are ignored, then the ideal expected present value of a Continental dollar would have instantly appreciated to within a few percentage points of face value that year. However, Congress allowed states to remit their quotes at a rate of 40 Continental dollars to one Spanish silver dollar. If this rate was what states then turned around and used tax-wise to acquire Continental dollars from their citizens, then the present value of a Continental dollar would be 2.5 percent of its face value, see Table 3.4 and Figure 3.5. This present value, however, is predicated on redemption being fully completed by May 1781, which it was not. Congress continued to credit state remittances at the 40 to 1 paper to silver dollar rate into $1790 .^{65}$

In addition, seemingly in conjunction with the 18 March 1780 resolution, Congress

\footnotetext{
$64 J C C$ (v. 16, p. 267). For prior North-South vote splitting over finance issues, see JCC (v. 12, pp. 1257-8, 1266). 65 See Archives of Maryland (v. 43, pp. 258-9); Bolles (1969, v. 1, pp. 97-8, 135-6); Boyd (1953, v. 7, pp. 221-3); Bullock (1895, pp. 136-8; 1900, p. 72); Elliot (1843, pp. 67, 77-82); Ferguson, et al. (1975, v. 2, pp. 70-1); Grubb (2012a, pp. 160-1); JCC (v. 16, pp. 165, 217, 253, 262-7, 269; v. 23, pp. 560-1, 590); Phillips (1866, pp. 160-6); Sumner (1968, v. 1, pp. 87-9); Webster (1969, p. 111). See also Smith (1981, v. 8, p. 366; 1985, v. 11, pp. 306-7, 382; 1986, v. 13, pp. 351-2, 388, 603-4; 1987, v. 14, pp. 463-4, 500, 506, 514, 519-32).
} 
recommended on 20 March 1780 that the states “...revise their laws...making the continental bills of credit a tender in discharge of debts and contracts, and to amend the same in such manner as they shall judge most conducive to justice, in the present state of the paper currency..." From late 1780 through mid-1781 states complied by revoking their laws making the Continental dollar a legal tender in their respective states. For example, Delaware passed its law revoking the legal tender status of the Continental dollar on 8 November 1780; New Jersey on 5 January 1781; Virginia on 5 May 1781; and Pennsylvania made its temporary suspension of legal tender status permanent on 21 June $1781 .{ }^{66}$ The removal of legal tender laws in conjunction with the new redemption structure legislated 18 March 1780 freed the states to redeem Continental dollars from their citizens at whatever current value they wished to legislate or at whatever rate they could impose on the market. It effectively broke the link between redemption per se and redemption at face value in specie.

The ideal present value calculation for the 18 March 1780 resolution is predicated on redemption at face value being certain, i.e. fiscally feasible, which it was not. Table 3.4 shows that the per year per white-capita tax level needed to accomplish the 18 March 1780 redemption structure was multiple times above historically acceptable and fiscally feasible limits. Even using the 40 to 1 paper to specie dollar conversion rate for state remittances, the per year per whitecapita tax level was still 6.6 time above that established in 1775 for the first two emissions of Continental dollars. It was also 1.6 times above the level achieved by the Federal Government from 1792 through 1795 after it had acquired direct taxing powers under the U.S. Constitution. These observations raise questions about the fiscal credibility of this resolution's redemption

${ }^{66}$ See Acts of the council and general assembly of New-Jersey (1784, p. 157); Grubb (2012b); Hening (1969, v. 13, pp. 412-3); JCC (v. 16, p. 269); Laws of the state of Delaware (1797, v. 2, pp. 718-9); Smith (1986, v. 13, p. 129; 1988, v. 15, p. 295; 1990, v. 17, p. 87); Statutes at large of Pennsylvania (1904, v. 10, pp. 204-5, 228-9, 247-9, 33744). 
structure and thus about the presumed certainty of redemption as promised, which is needed to make an ideal expected present value calculation. Thus, an ideal expected present value calculation may not be valid for the 18 March 1780 redemption structure. The issue of credible commitment will be taken up in more detail in a future paper.

Given these caveats, the calculated ideal expected present value of a Continental dollar under the 18 March 1780 redemption may have been outside the bounds of reality. As such, Forecasts 1 and 2 are used as counterfactual ideal expected present value estimates under the assumption that the new redemption window legislated in 1780 was not operative. They, rather than the 18 March 1780 redemption structure, should be used as the most credible benchmark against which empirical measures of depreciation should be evaluated. Again, this is because the ideal must be based on certainty of redemption, and thus the fiscal credibility of the redemption taxes required. The 18 March 1780 redemption structure was not so based, while Forecasts 1 and 2 were.

In summary, calculating the ideal expected present values of a Continental dollar for the legislated redemption resolutions of 2 January 1779 and 18 March 1780 are dubious exercises. Such calculations are outside the bounds of reality in that they entail tax levels that were not realistic and so not credible in terms of the certainty of redemption. In their place, Forecasts 1 and 2 are projected past 1778 to 1790 as the best benchmark ideal expected present value of a Continental dollar for these years, see Figure 3.5. These projections are counterfactual estimates under the assumption that the 1779 and 1780 redemption resolutions were not operative. They embed realistic constraints that make redemption fiscally credible and so certain. These benchmarks will be used in future papers to evaluate empirical measures of depreciation and the credibility of Congress' commitment to the Continental dollar. 


\section{THE CUMULATIVE VALUE OF CONTINENTAL DOLLARS EMITTED, 1775-1780}

Table 3.5 presents the cumulative value of Continental dollars emitted and currently outstanding over the period of active emissions from August 1775 through November 1779. The time-path of the cumulative face value, as well as the cumulative present value using Forecasts 1 and 2 under perfect foresight, are presented. For 1779, the cumulative present values, both for the counterfactual applications of Forecasts 1 and 2 and for the new 2 January 1779 redemption structure, are reported.

When an amount was authorized, it was not instantly put into circulation. Some lag existed between authorization and the spending of the bills by Congress. That lag is currently unknown. From the comments in the $J C C$, the longest lag was with the first emission. Substantial portions of that emission did not go into circulation until the fall of 1775 . Thereafter, from the statements by Congress that the Continental Treasury was empty prior to authorizing the next issuance of bills, and from a rough tracking of the spending resolutions in the $J C C$, it appears that each new authorized amount was spent between its initial authorization and the next authorization of a new issuance of bills. ${ }^{67}$ Thus, the cumulative flows reported in Table 3.5 are reasonably accurate from authorization date to authorization date.

While the flow of spending between authorized amounts is currently unknown, the range of that flow is depicted in Figure 3.7. Given that the public expected that a given authorized amount would be spent before the next new amount was authorized, once Congress told the public the amount being currently authorized, the public would know the amount that would be soon spent. Therefore, because all bills from an authorization were put into circulation by the next amount authorized, a low estimate of the amount currently in circulation is the cumulative

${ }^{67}$ See JCC (v. 2-16; especially v. 2, pp. 237, 245; v. 3, pp. 275, 342, 345, 387); Michener (1988, p. 686); Smith (1977, v. 2, pp. 166, 355, 379-80; 1979, v. 5, pp. 521, 611; 1980, v. 6, pp. 79, 117-8, 146, 212-4, 270; 1981, v. 7, p. 304; 1982, v. 9, p. 479; 1987, v. 14, pp. 288-9, 547; 1998, v. 25, p. 683). 
Table 3.5 Cumulative Values of Continental Dollars Emitted and Currently Outstanding, 1775-1780

\begin{tabular}{|c|c|c|c|c|c|}
\hline \multirow{2}{*}{$\begin{array}{l}\text { Procedural } \\
\text { Authorization } \\
\text { Dates } \\
\text { July 29, } 1775\end{array}$} & \multirow{2}{*}{$\begin{array}{l}\text { Date Printed } \\
\text { on the Bill } \\
\text { (Emission \#) }\end{array}$} & \multirow{2}{*}{$\begin{array}{l}\text { Face Value of } \\
\text { New Emission } \\
\$ 3,000,000^{\mathrm{a}}\end{array}$} & \multirow{2}{*}{$\begin{array}{l}\text { Face Value of } \\
\text { Cumulative } \\
\text { Emissions } \\
\text { to Date } \\
\qquad \$ 3,000,000\end{array}$} & \multicolumn{2}{|c|}{$\begin{array}{l}\text { Expected Present Value Discounted at 6\% } \\
\text { of Cumulative Emissions to Date Using: } \\
\text { Forecast } 1 \quad \text { Forecast } 2 \\
\text { (Discount Factor) }\end{array}$} \\
\hline & & & & $\begin{array}{r}\$ 2,091,900 \\
(0.6973)\end{array}$ & $\begin{array}{r}\$ 2,091,900 \\
(0.6973)\end{array}$ \\
\hline Dec. 26, 1775 & $\begin{array}{l}\text { Nov. 29, } 1775 \\
\text { (Emission \#2) }\end{array}$ & $\$ 3,000,000$ & $\$ 6,000,000$ & $\begin{array}{r}\$ 3,862,200 \\
(0.6437)\end{array}$ & $\begin{array}{r}\$ 3,862,200 \\
(0.6437)\end{array}$ \\
\hline Feb. 21, 1776 & $\begin{array}{l}\text { Feb. 17, } 1776 \\
\text { (Emission \#3) }\end{array}$ & $\$ 3,937,220$ & $\$ 9,937,220$ & $\begin{array}{r}\$ 5,685,084 \\
(0.5721)\end{array}$ & $\begin{array}{r}\$ 5,680,115 \\
(0.5716)\end{array}$ \\
\hline May 22, 1776 & $\begin{array}{l}\text { May 9, } 1776 \\
\text { (Emission \#4) }\end{array}$ & $\$ 5,000,000$ & $\$ 14,937,220$ & $\begin{array}{r}\$ 7,540,309 \\
(0.5048)\end{array}$ & $\begin{array}{r}\$ 7,525,371 \\
(0.5038)\end{array}$ \\
\hline Aug. 13, 1776 & $\begin{array}{l}\text { July 22, } 1776 \\
\text { (Emission \#5) }\end{array}$ & $\$ 5,000,000$ & $\$ 19,937,220$ & $\begin{array}{r}\$ 9,101,341 \\
(0.4565)\end{array}$ & $\begin{array}{r}\$ 9,041,529 \\
(0.4535)\end{array}$ \\
\hline Nov. 2, 1776 & $\begin{array}{l}\text { Nov. 2, } 1776 \\
\text { (Emission \#6) }\end{array}$ & $\$ 5,000,000$ & $\$ 24,937,220$ & $\begin{array}{r}\$ 10,398,821 \\
(0.4170)\end{array}$ & $\begin{array}{r}\$ 10,338,971 \\
(0.4146)\end{array}$ \\
\hline Feb. 26, 1777 & $\begin{array}{l}\text { Feb. 26, } 1777 \\
\text { (Emission \#7) }\end{array}$ & $\$ 5,000,000$ & $\$ 29,937,220$ & $\begin{array}{r}\$ 11,531,817 \\
(0.3852)\end{array}$ & $\begin{array}{r}\$ 11,504,874 \\
(0.3843)\end{array}$ \\
\hline May 22, 1777 & $\begin{array}{l}\text { May 20, } 1777 \\
\text { (Emission \#8) }\end{array}$ & $\$ 5,000,000$ & $\$ 34,937,220$ & $\begin{array}{r}\$ 4,685,081 \\
(0.1341)\end{array}$ & $\begin{array}{r}\$ 3,357,467 \\
(0.0961)\end{array}$ \\
\hline Aug. 15, 1777 & 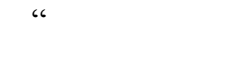 & $\$ 1,000,000$ & $\$ 35,937,220$ & $\begin{array}{r}\$ 4,891,056 \\
(0.1361)\end{array}$ & $\begin{array}{r}\$ 3,503,879 \\
(0.0975)\end{array}$ \\
\hline Nov. 7,1777 & “ & $\$ 1,000,000$ & $\$ 36,937,220$ & $\begin{array}{r}\$ 5,101,030 \\
(0.1381)\end{array}$ & $\begin{array}{r}\$ 3,653,091 \\
(0.0989)\end{array}$ \\
\hline Dec. 3,1777 & “" & $\$ 1,000,000$ & $\$ 37,937,220$ & $\begin{array}{r}\$ 5,265,686 \\
(0.1388)\end{array}$ & $\begin{array}{r}\$ 3,770,960 \\
(0.0994)\end{array}$ \\
\hline Jan. $\quad 8,1778$ & “ & $\$ 1,000,000$ & $\$ 38,937,220$ & $\begin{array}{r}\$ 5,431,742 \\
(0.1395)\end{array}$ & $\begin{array}{r}\$ 3,889,828 \\
(0.0999)\end{array}$ \\
\hline Jan. 22, 1778 & “ & $\$ 2,000,000$ & $\$ 40,937,220$ & $\begin{array}{r}\$ 5,710,742 \\
(0.1395)\end{array}$ & $\begin{array}{r}\$ 4,089,628 \\
(0.0999)\end{array}$ \\
\hline Feb. 16, 1778 & “ & $\$ 2,000,000$ & $\$ 42,937,220$ & $\begin{array}{r}\$ 6,019,798 \\
(0.1402)\end{array}$ & $\begin{array}{r}\$ 4,315,191 \\
(0.1005)\end{array}$ \\
\hline Mar. 5, 1778 & “" & $\$ 2,000,000$ & $\$ 44,937,220$ & $\begin{array}{r}\$ 6,336,148 \\
(0.1410)\end{array}$ & $\begin{array}{r}\$ 4,538,659 \\
(0.1010)\end{array}$ \\
\hline Apr. 4, 1778 & “" & $\$ 1,000,000$ & $\$ 45,937,220$ & $\begin{array}{r}\$ 6,509,304 \\
(0.1417)\end{array}$ & $\begin{array}{r}\$ 4,662,628 \\
(0.1015)\end{array}$ \\
\hline Apr. 11, 1778 & $\begin{array}{l}\text { Apr. 11, } 1778 \\
\text { (Emission \#9) }\end{array}$ & $\$ 5,000,000$ & $\$ 50,937,220$ & $\begin{array}{r}\$ 7,217,801 \\
(0.1417)\end{array}$ & $\begin{array}{r}\$ 5,170,128 \\
(0.1015)\end{array}$ \\
\hline Apr. 18, 1778 & $\begin{array}{l}\text { May 20, } 1777 \\
\text { (Emission \#8) }\end{array}$ & $\$ 500,000$ & $\$ 51,437,220$ & $\begin{array}{r}\$ 7,288,651 \\
(0.1417)\end{array}$ & $\begin{array}{r}\$ 5,220,878 \\
(0.1015)\end{array}$ \\
\hline May 22, 1778 & $\begin{array}{l}\text { Apr. 11, } 1778 \\
\text { (Emission \#9) }\end{array}$ & $\$ 5,000,000$ & $\$ 56,437,220$ & $\begin{array}{r}\$ 8,036,660 \\
(0.1424)\end{array}$ & $\begin{array}{r}\$ 5,756,596 \\
(0.1020)\end{array}$ \\
\hline June 20, 1778 & “ & $\$ 5,000,000$ & $\$ 61,437,220$ & $\begin{array}{r}\$ 8,791,666 \\
(0.1431)\end{array}$ & $\begin{array}{r}\$ 6,297,315 \\
(0.1025)\end{array}$ \\
\hline July 30, 1778 & “ & $\$ 5,000,000$ & $\$ 66,437,220$ & $\begin{array}{r}\$ 9,553,672 \\
(0.1438)\end{array}$ & $\begin{array}{r}\$ 6,843,034 \\
(0.1030)\end{array}$ \\
\hline Sept. 5, 1778 & “ & $\$ 5,000,000$ & $\$ 71,437,220$ & $\begin{array}{r}\$ 10,379,828 \\
(0.1453)\end{array}$ & $\begin{array}{r}\$ 7,436,615 \\
(0.1041)\end{array}$ \\
\hline Sept. 26, 1778 & $\begin{array}{l}\text { Sept. 26, } 1778 \\
\text { (Emission \#10) }\end{array}$ & $\$ 10,000,100$ & $\$ 81,437,320$ & $\begin{array}{r}\$ 11,832,843 \\
(0.1453)\end{array}$ & $\begin{array}{r}\$ 8,477,625 \\
(0.1041)\end{array}$ \\
\hline Nov. 4, 1778 & “ & $\$ 10,000,100$ & $\$ 91,437,420$ & $\begin{array}{r}\$ 13,413,870 \\
(0.1467)\end{array}$ & $\begin{array}{r}\$ 9,610,073 \\
(0.1051)\end{array}$ \\
\hline
\end{tabular}




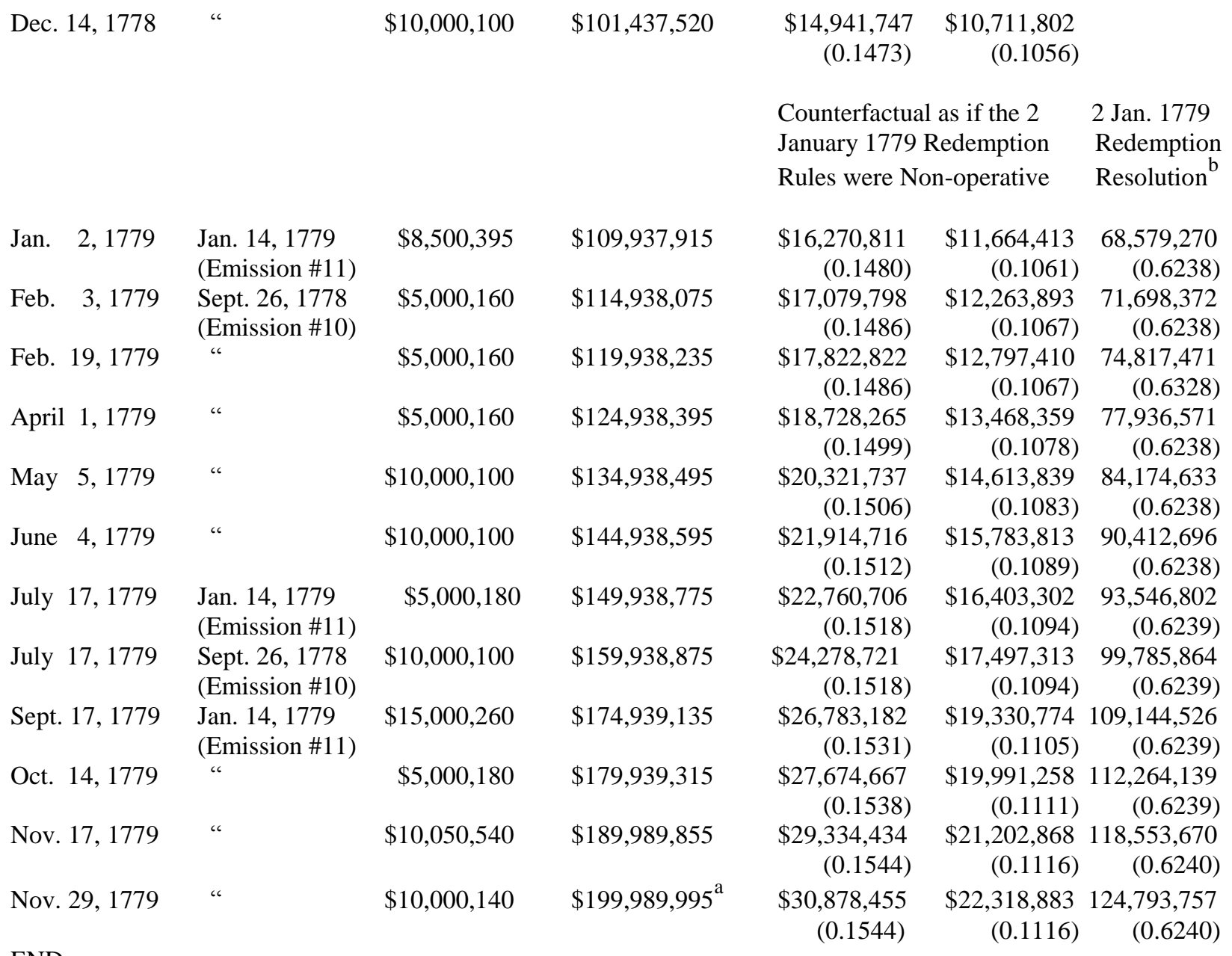

END

Sources: Derived from Tables 3.1 and 3.4.

Notes: After emission \#7 the perfect foresight assumption is used for Forecasts 1 and 2, see Table 3.4.

${ }^{\mathrm{a}}$ See note d of Table 3.1.

${ }^{b}$ These values assume that redemption could and would be executed as legislated. Given that this plan was not fiscally credible, these values are presented for comparative purposes only. See the text for further discussions.

amount of past authorizations on the date Congress authorized the next new amount to be issued. A high estimate is the cumulative amount of past authorizations on the date Congress authorized the next new amount to be issued, inclusive of that new amount. Figure 3.7 presents these high and low estimates for the cumulative face value in circulation over time. Up to mid-1777, the gap between the high and low estimate is about $\$ 3$ to $\$ 5$ million. Between mid-1777 and mid-1778, the gap is \$1 to \$3 million. After mid-1778 the gap grows to between $\$ 10$ and $\$ 20$ million. 


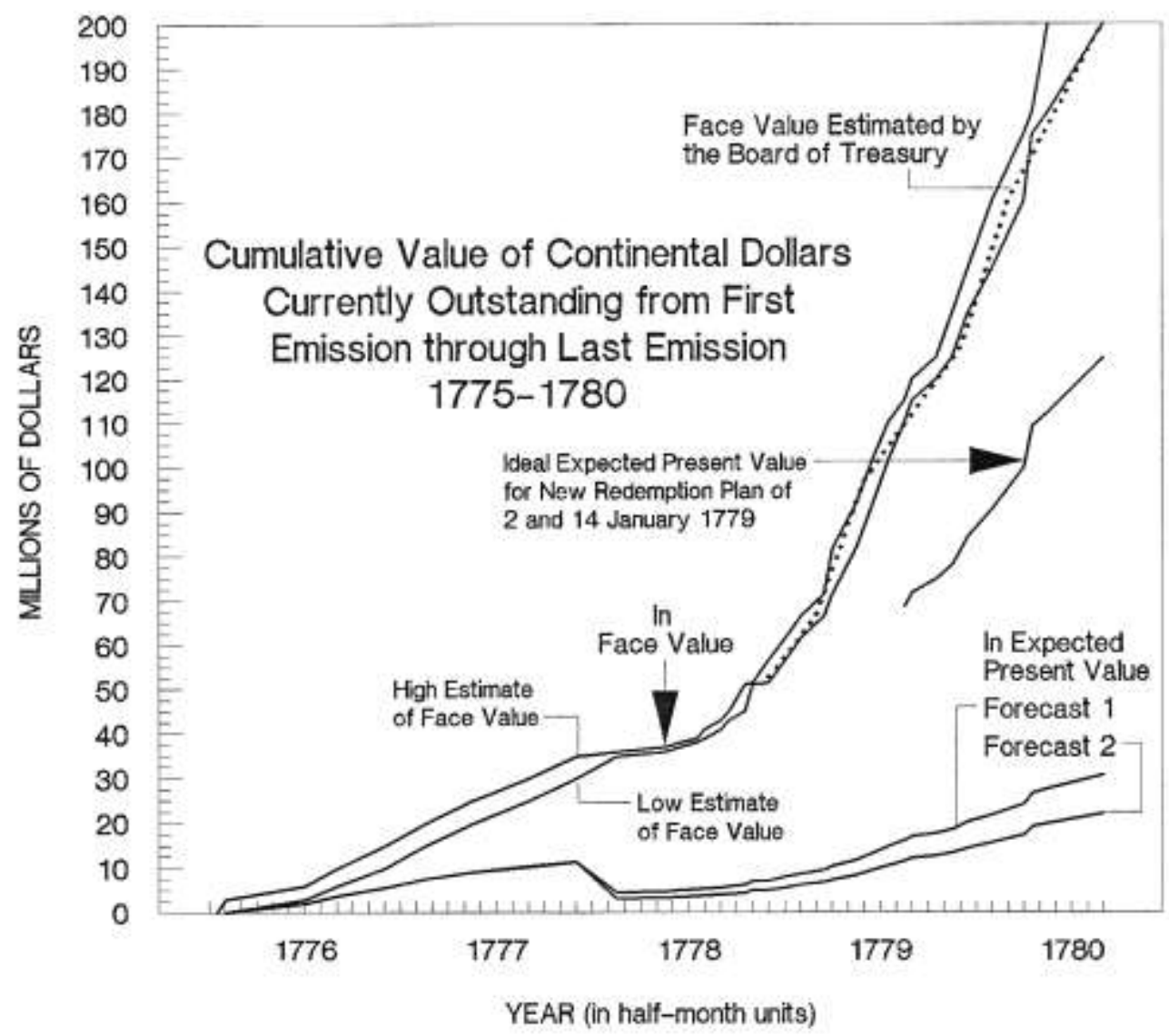

Figure 3.7 Cumulative Value of Continental Dollars Emitted and Currently Outstanding from First Emission to Last, 1775 through 1780

Sources and Notes: See Tables 3.5; Early American imprints (1983, microfiche S 269, nos. 16634, 16635; 'U.S. Board of Treasury, 1779, A Table of First Year's Interest. Philadelphia, 1779' and 'U.S. Board of Treasury, 1779. Table of the Sums Actually in Circulation. Philadelphia, 3 December 1779', respectively).

On 3 December 1779, the Board of Treasury reported the cumulative face value amount in circulation each day from 1 June 1778 through 28 February 1779, and each day from 1 June 1779 through 28 February 1780. While the Board claimed these were the actual amounts in circulation, they must have been estimates as the incremental increase from day to day is too consistently the same number to capture the actual day-to-day flow of spending that put Continental dollars into circulation. The Board's report assumes that Continental dollar emissions would total $\$ 200$ million in face value with that entire sum still in circulation by the 
end of February 1780.

Figure 3.7 shows the Board's estimate. Except for a brief period in late 1779, the Board's estimate tracks the low estimate shown in Figure 3.7 for the cumulative face value in circulation. This indicates that a good estimate of the cumulative face value amount in circulation on any date would be to take the cumulative amount authorized so far in Table 3.5 and place that amount on the date listed for the next authorized sum. The Board's estimate also indicates that they expected that the last sums authorized, those in late November 1779 amounting to \$20 million in face value, would take three months to put into circulation.

The trajectory of the cumulative face-value sums in circulation was approximately linear from August 1775 through mid-1777, with \$1,455,718 added on average each month. From August 1777 through December 1777 this trajectory briefly flattened out, with only \$600,000 added on average each month. This flattening of the trajectory coincided with the adoption of legal tender laws. Thereafter, the trajectory changed to a steeper linear path, with \$6,232,799 added on average each month from January 1778 through February 1780.

Figure 3.7 also shows the cumulative amount in circulation in present value. The timepath of these cumulative flows uses the low-estimate method, namely placing each sum presented in Table 3.5 at the next authorization date and the last sum on 28 February 1780. From August 1775 through March 1777, the cumulative present value in circulation, while rising at a slower pace than the cumulative face value, was roughly half that of the cumulative face value. The trajectories of the cumulative face value and the cumulative present value parted ways around March of 1777. This departure coincided with the adoption of legal tender laws, and illustrates the dramatic effect those laws had on the cumulative present value of Continental dollars compared with their cumulative face value. From March to June 1777, cumulative 
present values collapsed 30 to 40 percent, while cumulative face values continued to grow.

Cumulative present values did not recover to their March 1777 level until between October 1778 and January 1779.

The temporary gain in the purchasing power of new emissions gained by Congress with the adoption of legal tender laws, see Figure 3.4, coincided with the deceleration in the growth of the cumulative face value in circulation from March 1777 to January 1778. This gain came not only at the cost of the collapse in the present value of the cumulative sums in the hands of the public, but at the cost of accelerating the eventual collapse of the Continental dollar financing system. Figure 3.7 shows that beginning in 1778 the growth in cumulative face value accelerated relative to the growth in cumulative present values. The relatively constant widening gap between their trajectories before March 1777 became an accelerating widening gap. It took an ever increasing amount of face value emissions to generate a given increase in cumulative present values. This widening gap meant that after January 1778 the Continental dollar financial system would be unsustainable in the long run-a long run that was likely not that far off.

Table 3.5 and Figure 3.7 also illustrate the idealized effort by Congress on 2 January 1779 to reflate present values through the adoption of a new redemption structure. If that structure had been credible, it would have pushed the cumulative present value to approximately 62 percent of the cumulative face value. In addition, the trajectory of this cumulative present value through 1779 would have been only slightly less than that for the cumulative face value, roughly \$5 million versus \$8 million added on average per month, respectively. If this redemption plan had worked, it would have made the Continental dollar financial system sustainable for much longer. Figure 3.7 helps make sense of what Congress was attempting to do in 1779 compared with the continue-as-before alternative. That they failed to understand that a 
successful execution of this change was unlikely will be taken up in future papers.

Table 3.4 and Figure 3.5 provide the key points of this paper. The time-paths illustrated by Forecasts 1 and 2 are the ideal present values of a Continental dollar under certainty of redemption and zero depreciation. Future papers will use these present values as benchmarks to evaluate empirical measures of depreciation and the ideal present value of loan office certificates. Figures 3.4, 3.5, and 3.7 also illustrate the importance of legal tender laws. Their adoption dramatically altered the present value of the Continental dollar. The history, purpose, costs, and benefits of these laws — what they could and could not do — were poorly understood by contemporaries and in current scholarship (Grubb 2012b). Because understanding legal tender laws is critical to the story, they will be addressed in more detail with regard to the Continental dollar in a future paper.

\section{References (for the entire project so far)}

Acts of the council and general assembly of New-Jersey. 1784. Trenton, NJ.

American almanac and repository of useful knowledge for the year 1830, vol. 1. 1830. Boston: Gray and Bowen.

American state papers. class III, finance, vol. 1. [Documents, legislative and executive of the Congress of the United States, from the first session of the eighteenth Congress to the first session of the twentieth Congress: commencing April 19,1824, and ending May 16, 1828. On Finance. vol. 5.]. 1832. Washington: Gales and Seaton.

American state papers. class IX, claims, vol. 1. [Documents, legislative and executive of the Congress of the United States, vol. \{blank\}]. 1834. Washington: Gales and Seaton.

Anderson, William G. 1983. The price of liberty: the public debt of the American Revolution. Charlottesville, VA: University Press of Virginia.

Archives of Maryland, vols. 1-72. 1883-1972. Baltimore, MD: Maryland Historical Society.

Atack, Jeremy, and Passell, Peter 1994. A new economic view of American history. New York: W. W. Norton, $2^{\text {nd }}$ edn.

Baack, Ben 2001. 'Forging a nation state: the Continental Congress and the financing of the War of American Independence', Economic History Review 54: 639-56.

2008. 'America's first monetary policy: inflation and seigniorage during the Revolutionary War', Financial History Review 15: 107-21. 
Barlow, J. Jackson (ed.) 2012. To secure the blessings of liberty: selected writings of Gouverneur Morris. Indianapolis, IN: Liberty Fund.

Bezanson, Anne 1951. Prices and inflation during the American Revolution: Pennsylvania, 1770-1790. Philadelphia: University of Pennsylvania Press.

Bolles, Albert S. 1969. The financial history of the United States from 1774 to 1789, vols.1-3. New York: Augustus M. Kelly, [original 1884].

Boyd, Julian P. (ed.) 1954-1955. The papers of Thomas Jefferson, vols. 7-12. Princeton, NJ: Princeton University Press.

Breck, Samuel 1843. Historical sketch of Continental paper money. Philadelphia: John C. Clark.

Bronson, Henry 1865. 'A historical account of Connecticut currency, Continental money, and the finances of the Revolution', Papers of the New Haven Colony Historical Society 1: 1-192 [New Haven, CT: Thomas J. Stafford, printer].

Brock, Leslie V. 1975. The currency of the American colonies, 1700-1764. New York: Arno.

Brookhiser, Richard 2003. Gentleman revolutionary: Gouverneur Morris, the rake who wrote the Constitution. New York: Free Press.

Brown, Roger H. 1993. Redeeming the republic. Baltimore.

Buel, Richard Jr. 1998. In irons: Britain's naval supremacy and the American revolutionary economy. new Haven, CT: Yale University Press.

Bullock, Charles J. 1895. The finances of the United States from 1775 to 1789 . Madison, WI: University of Wisconsin Press. 1900. Essays on the monetary history of the United States. New York: Macmillan.

Bush, Bernard (ed.) 1980. Laws of the royal colony of New Jersey, 1746-1760. Trenton, NJ: New Jersey State Library, Bureau of Archives and History.

1982. Laws of the royal colony of New Jersey, 1760-1769. Trenton, NJ: New Jersey State Library, Bureau of Archives and History.

1986. Laws of the royal colony of New Jersey, 1770-1775. Trenton, NJ: Division of Archives and Records Management, New Jersey Department of State.

Calomiris, Charles W. 1988. 'Institutional failure, monetary scarcity, and the depreciation of the Continental', Journal of Economic History 48: 47-68.

Carter, Susan B., et al. (eds.) 2006. Historical statistics of the United States earliest times to the present millennial edition, volumes 1 and 5. New York: Cambridge University Press.

Cooke, Ebenezer 1730. Sotweed redivivus: or the planters looking-glass. Annapolis, MD.

Cushing, John D. (ed.) 1981. The first laws of the state of Delaware, vol. 2, part 1. Wilmington, DE: Michael Glazier, State Printer of Delaware.

Davis, Andrew McFarland 1964. Colonial currency reprints, 1682-1751, vols. 1-4. New York: Augustus M. Kelley.

De Knight, William F. 1900. History of the currency of the country and of the loans of the United States from the earliest period to June 30, 1900. Washington, DC: Office of the Register of the Treasury, Government Printing Office.

Early American imprints, 1639-1800: based on the 13-volume Charles Evans bibliography, including supplements and corrections to Evans. 1983[?]. New York: Readex Microprint Corporation, microfiche S 269, nos. 16634, 16635.

Elliot, Jonathan 1843. 'Funding system of the United States and Great Britain', House of Representatives Document No. 15 (Vol. II. Executive Documents), $28^{\text {th }}$ Congress, $1^{\text {st }}$ Session, Read on Dec. 16, 1843. [Reprinted 1971. New York: Burt Franklin]. 
Farrand, Max (ed.) 1966. The records of the Federal Convention of 1787, vols. 1-4. New Haven CT: Yale University Press.

Ferguson, E. James 1953. 'Currency finance: an interpretation of colonial monetary practices', William and Mary Quarterly Third Series, 10: 153-80.

1961. The power of the purse. Chapel Hill, NC: University of North Carolina Press.

et al. (eds.) 1973-1999. The papers of Robert Morris, 1781-1784, vols. 1-9. Pittsburgh, PA: University of Pittsburgh Press.

Fisher, Edgar Jacob 1911. New Jersey as a royal province, 1738 to 1776. New York: Columbia University, Longman, Green \& Co.

Fortescue, John William 1910-1930. History of the British army. London: Macmillan.

Fowler, William M. Jr. 2011. American crisis: George Washington and the dangerous two years after Yorktown, 1781 -1783. New York: Walker \& Company.

Garber, Peter M. 1991. ‘Alexander Hamilton's market-based debt reduction plan', Carnegie-Rochester Conference Series on Public Policy 35: 79-104.

Gouge, William M. 1833. A short history of paper money and banking in the United States. Philadelphia, PA: T. W. Ustick.

Grubb, Farley 2003. 'Creating the U.S.-dollar currency union, 1748-1811: a quest for monetary stability or a usurpation of state sovereignty for personal gain?' American Economic Review 93: 1778-98.

2005. 'State 'currencies' and the transition to the U.S. dollar: reply_including a new view from Canada', American Economic Review 95: 1341-8.

2006. 'The U.S. Constitution and monetary powers: an analysis of the 1787 Constitutional Convention and the Constitutional transformation of the U.S. monetary system', Financial History Review 13: 43-71.

2007a. 'The net worth of the U.S. Federal government, 1784-1802', American Economic Review-Papers and Proceedings 97: 280-4.

2007b. 'The constitutional creation of a common currency in the U.S.: monetary stabilization versus merchant rent seeking', in Lars Jonung and Jurgen Nautz, eds., Conflict potentials in monetary unions. Stuttgart: Franz Steiner Verlag: 19-50.

2008. 'The Continental dollar: how much was really issued?' Journal of Economic History 68: 283-91.

2010. 'Testing for the economic impact of the U.S. Constitution: purchasing power parity across the colonies versus across the states, 1748-1811', Journal of Economic History 70: 118-45.

2011a, 'U.S. land policy: founding choices and outcomes, 1781-1802', in Douglas A. Irwin and Richard Sylla, eds., Founding choices. Chicago: University of Chicago Press and NBER: 259-89.

2011b. 'The distribution of Congressional spending during the American revolution, 1775-1780: the problem of geographic balance', in Stephen Conway and Rafael Torres Sánchez, eds., The spending of the states-military expenditure during the long eighteenth century: patterns, organisations, and consequences, 1650-1815. Saabrücken, Germany: VDM Verlag Dr. Müller GmbH \& Co. KG: 257-84.

2012a. 'State redemption of the Continental dollar, 1779-90', William and Mary Quarterly Third Series, 69: 147-80.

2012b. 'Is paper money just paper money? Experimentation and local variation in the fiat paper monies issued by the colonial governments of British North America, 1690-1775: part I', NBER working paper \#17997, http://www.nber.org/papers/w17997.

2012c. 'Chronic specie scarcity and efficient barter: the problem of maintaining an outside money supply in British colonial America’, NBER working paper \#18099, http://www.nber.org/papers/w18099.

2014. 'Colonial New Jersey Paper Money, 1709-1775: Asset Present Value Versus Liquidity Premium', working paper in progress, contact author. 
Hammond, Isaac W. (ed.) 1889a. 'Record of the commissioners' meeting at New Haven, 1778', Collection of the New Hampshire Historical Society 9: 272-95.

1889b. 'Record of a meeting of commissioners from the states of Massachusetts, New Hampshire and Connecticut, 1780', Collection of the New Hampshire Historical Society 9: 295-303.

Harlow, Ralph Volney 1929. 'Aspects of revolutionary finance, 1775-1783', American Historical Review 35: 46-68.

Hening, W. W. (ed.) 1969. The statutes at large: being a collection of all the laws of Virginia, vols. 9 and 13. Charlottesville, VA: University Press of Virginia [original 1821, 1823].

Hepburn, A. Barton 1967. A history of currency in the United States. New York: Augustus M. Kelly [original revised \& enlarged edition 1924].

Hobson Charles F., and Rutland, Robert A. (eds.) 1981. The papers of James Madison, vol. 13. Charlottesville, VA: University Press of Virginia.

Holton, Woody 2007. Unruly Americans and the origins of the Constitution. New York: Hill and Wang.

Homer, Sidney and Sylla, Richard 1991. A history of interest rates. New Brunswick, NJ: Rutgers University Press, $3^{\text {rd }}$ edn.

Hughes, Jonathan, and Cain, Louis P. 2007. American economic history. New York: Pearson Education Inc., $7^{\text {th }}$ edn.

Hutchinson, William T., and Rachal, William M. E. (eds.) 1962-1965. The papers of James Madison, Vols. 1-4. Chicago: University of Chicago Press.

Jensen, Merrill 1950. The new nation. New York.

Journals of the Continental Congress, 1774-1789, vols. 1-34. [JCC hereafter] 1904-1937. Washington D.C.: Government Printing Office.

Kaminski, John P., and Saladino, Gaspare J. (eds.) 1981. The documentary history of the ratification of the Constitution, vol. 13: commentaries on the Constitution, public and private, vol. 1, 21 February to 7 November 1787. Madison, WI: State Historical Society of Wisconsin.

Kemmerer, Donald L. 1940. Path to freedom: the struggle for self-Government in colonial New Jersey, 1703-1776. Princeton, NJ: Princeton University Press.

1956. 'A history of paper money in colonial New Jersey, 1668-1775', Proceedings of the New Jersey Historical Society 74: 107-44.

Labaree, Leonard W. (ed.) 1967-1970. The papers of Benjamin Franklin, vols. 11-14. New Haven, CT: Yale University Press.

Laws of the state of Delaware. 1797. Newcastle, DE.

Lester, Richard A. 1938. 'Currency issues to overcome depressions in Delaware, New Jersey, New York and Maryland, 1715 37', Journal of Political Economy 46: 324-75.

Lint, Gregg L. (ed.) 1996. Papers of John Adams, vol. 9. Cambridge, MA: The Belknap Press of Harvard University Press.

Lopez, Claude A. (ed.) 1988. The papers of Benjamin Franklin, vol. 27. New Haven, CT: Yale University Press.

McCusker, John J. 1978. Money and exchange in Europe and America, 1600-1775. Chapel Hill, NC: University of North Carolina Press.

Mevers, Frank C. (ed.) 1979. Papers of Josiah Bartlett. Hanover, NH: University Press of New England.

Michener, Ron 1988. 'Backing theories and the currencies of eighteenth-century America: a comment', Journal of Economic History 48: 682-92.

Nettels, Curtis Putnam 1934. The money supply of the American colonies before 1720. Madison, WI: University of Wisconsin Press. 
Newman, Eric P. 1959. 'The successful British counterfeiting of American paper money during the American Revolution', The British Numismatic Journal: 174-87.

1997. The early paper money of America. Iola, WI: Krause Publications, $4^{\text {th }}$ edn.

2008. The early paper money of America. Iola, WI: Krause Publications, $5^{\text {th }}$ edn.

Nourse, Joseph, 'Statements of the receipts and expenditures of the public monies, during the administration of the finances by Robert Morris', submitted to the committee of the House of Representatives of the United States on the memorial of Robert Morris, 30 August 1790, reprinted in James E. Ferguson, et al., eds., The papers of Robert Morris, 1781-1784, vols. 1-9. Pittsburgh, PA: University of Pittsburgh Press, 1973-1999, v. 9: 905-40.

1828. 'Amount of Continental money issued during the Revolutionary War and the depreciation of the same', House document No. 107, $20^{\text {th }}$ Congress, $1^{\text {st }}$ Session, 30 January 1828. Washington D.C.: Gales \& Seaton.

Oberg, Barbara B. (ed.) 1992-1998. The papers of Benjamin Franklin, vols. 29-34. New Haven, CT: Yale University Press.

O'Shaughnessy, Andrew Jackson 2000. An empire divided: the American Revolution and the British Caribbean. Philadelphia: University of Pennsylvania Press.

Papers of the Continental Congress, 1774-1789. [PCC hereafter] Washington DC: National Archives Microfilm Publication, M247.

Perkins, Edwin J. 1994. American public finance and financial services, 1700-1815. Columbus, OH: Ohio State University Press.

Phillips, Henry Jr. 1866. Continental paper money: historical sketches of American paper currency, second series. Roxbury, MA: W. Elliot Woodward.

Puls, Mark 2008. Henry Knox, visionary general of the American Revolution. New York: Palgrave Macmillan.

Rabushka, Alvin 2008. Taxation in colonial America. Princeton, NJ: Princeton University Press.

Randall, William Sterne 1990. Benedict Arnold: patriot and traitor. New York: Barnes \& Noble Books.

Ratchford, U. B. 1941. American state debts. Durham, NC: Duke University Press.

Ricord, Frederick W. (ed.) 1892. Documents relating to the Colonial history of the State of New Jersey, vol. XVII. Trenton, NJ: John L. Murphy Publishing [Archives of the State of New Jersey, First Series, vol. XVII].

Robinson, Edward Forbes 1969. 'Continental Treasury Administration, 1775-1781: A study in the financial history of the American Revolution'. Unpublished PhD Dissertation, University of Wisconsin.

Rutland, Robert A., and Hobson, Charles F. (eds.) 1977-1979. The papers of James Madison, vols. 11-12. Charlottesville, VA: University Press of Virginia.

Sargent, Thomas J. 2012. ‘United States then, Europe now',https://files.nyu.edu/ts43/public/research/Sargent_Sweden_final.pdf [accessed 8 February 2013], Nobel Prize Lecture delivered 8 December 2011, Stockholm, Sweden.

Scott, Kenneth 1957. Counterfeiting in Colonial America. Philadelphia.

Sherwood, Joseph 1851. 'Letters of Joseph Sherwood [agent for New Jersey in Britain, 1761-1766]', Proceedings of the New Jersey Historical Society, First Series, 5: 147.

Smith, Adam 1937. The wealth of nations. New York: Modern Library.

Smith, Paul H. 1976-1994. Letters of delegates to Congress, 1774-1789, vols. 1-21. Washington, DC: Library of Congress.

Smyth, Albert Henry 1907. The writings of Benjamin Franklin, vol. 9. London: Macmillan.

Sparks, Jared 1832. The life of Gouverneur Morris, with selections from his correspondence and miscellaneous papers in three volumes. Boston: Gray \& Bowen. 
Statutes at large of Pennsylvania, vols. 9-10. 1903-1904. Harrisburg, PA: W.M. Stanley Ray, State Printer of Pennsylvania.

Sumner, William Graham 1968. The financier and the finances of the American Revolution, vols.1-2. New York: Augustus M. Kelly [original 1891].

Swanson, Donald F. 1963. The origins of Hamilton's fiscal policy. Gainesville, FL: University of Florida Press.

Syrett, Harold C., and Cooke, Jacob E., eds., 1963. The papers of Alexander Hamilton, vol. 7. New York: Columbia University Press.

Taylor, George Rogers (ed.) 1950. Hamilton and the national debt. Boston: D.C. Heath and Company.

Telser, Lester G. 1995. 'Optimal denominations for coins and currency’, Economics Letters 49: 425-7.

Tindall, George Brown 1988. America: a narrative history. New York: W. W. Norton, $2^{\text {nd }}$ edn.

United States Congress 1834-1856. The debates and proceedings in Congress of the United States, vols. 1-18. Washington DC: Gales \& Seaton.

United States Continental Congress s.n. 1775. Philadelphia?:http://memory.loc.gov/service/rbc/bdsdcc/00301/0001.jpg [accessed 30 January 2013].

Van Hove, Leo 2001. 'Optimal denominations for coins and bank notes: in defense of the principle of least effort', Journal of Money, Credit and Banking 33: 1015-21.

Ver Steeg, Clarence L. 1976. Robert Morris: revolutionary financier. New York: Octagon Books.

Walton, Gary M., and Rockoff, Hugh Rockoff 2005. History of the American economy. Mason, OH: South-Western, $10^{\text {th }}$ edn.

Webster, Pelatiah 1969. Political essays on the nature and operation of money, public finances and other subjects. New York: Burt Franklin [original 1791].

Williamson, John 1796. A treatise of military finance. London: Oxford University. 